\title{
Meteorit Potůčky (Steinbach): historie a nové nálezy (Česká republika)
}

\author{
Meteorite Potůčky (Steinbach): history and new finds (Czech Republic)

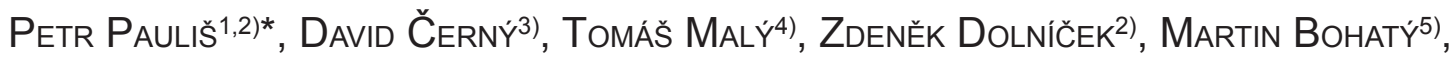 \\ Jana Ulmanová ${ }^{2)}$, Ondřej Pour ${ }^{6)}$, Jakub Plášil ${ }^{7)}$, OndŘej Malina ${ }^{8}$, Petr Bohdálek ${ }^{6}$, \\ IVAN SÝKORA ${ }^{9)}$ a PAVEL P. POVINEC ${ }^{9)}$ \\ 1)Smíškova 564, 28401 Kutná Hora; *e-mail: petr.paulis@post.cz \\ 2)Mineralogicko-petrologické oddělení, Národní muzeum, Cirkusová 1740, 19300 Praha 9 - Horní Počernice \\ 3)Merklín 23, 36234 Merklín \\ 4)Matouškova 265, 51263 Rovensko pod Troskami \\ 5)Radnická 7, 60200 Brno \\ 6)Česká geologická služba, Geologická 6, 15200 Praha 5 \\ 7)Fyzikální ústav AV ČR v.v.i., Na Slovance 2, 18221 Praha 8 \\ 8) Národní památkový ústav, územní odborné pracoviště v Lokti, Kostelní 81/25, 35733 Loket \\ 9) Katedra jadrovej fyziky a biofyziky, Fakulta matematiky, fyziky a informatiky, Univerzita Komenského, \\ 84248 Bratislava, Slovensko
}

Pauliš P, Černý D, Malý T, Dolniček Z, Bohatý M, Ulmanová J, Pour O, Plášll J, Malina O, Bohdálek P, Sýkora I, Povinec PP (2020) Meteorit Potůčky (Steinbach): historie a nové nálezy (Česká republika). Bull Mineral Petrolog 28(1): 179-202 ISSN 2570-7337

\begin{abstract}
In the years 2017 and 2019 two silicate-rich iron meteorites (IVA-an) with a total weight of over $7 \mathrm{~kg}$ were found during the collection of rock samples near the old mining locality Glücksburg near Potůčky in the Krušné hory/Erzgebirge Mountains. Subsequent research confirmed their structural, mineralogical and chemical similarity with the meteorites of the historical find called Steinbach. Due to the complicated circumstances of the finding of these meteorites (in addition to already recognized finds of Steinbach itself at Grimma, Rittersgrün in Saxony and Potůčky/Breitenbach in Bohemia), historical literary sources have been reviewed. In the study of mineralogical composition of both newly found meteorites, previously known and published data were confirmed, in several cases their data were refined (chromite, schreibersite and nickelphosphide). In addition, the presence of troilite-hosted veinlets of Fe-Ni sulfides mostly corresponding to Ni-rich binary mixtures troilite-godlevskite and troilite-heazlewoodite, and a supergene phosphate close to beraunite were found. In the final chapter, there a hypothetical area, in which the potential occurrence of additional pieces of meteorites of the Steinbach historical fall can be expected, is delineated. Based on the concentration of ${ }^{40} \mathrm{~K}$ radionuclide in the meteorite found, its radiation age can be estimated at $70 \pm 30$ million years.
\end{abstract}

Key words: iron IVA-an meteorite, Steinbach, new occurrence, history, mineral composition, Potůčky, Czech Republic

Obdrženo 26. 2. 2020; prijato 5. 6. 2020

\section{Úvod}

V srpnu 2017 bylo při sběru horninových vzorků nedaleko staré hornické lokality Glücksburg u Potůčků nalezeno meteoritické anomální železo s vysokým podílem silikátů náležející do skupiny IVA-an o celkové hmotnosti kolem 4 kg. Následný výzkum potvrdil jeho shodu s meteority historického nálezu Steinbach (Potůčky). K novému objevu došlo při archeologickém výzkumu montánního areálu Glücksburg (Rudná), sv. od Potůčků, kdy byla řada nálezů železných artefaktů (historické nástroje, želízka, hutní strusky apod.) z této lokality podrobena chemickému výzkumu. Vzhledem byl totiž tento meteorit, pokrytý kůrou oxidačních produktů, od nalezených artefaktů neodlišitelný. Na jaře 2019 vznikl projekt, který se zaměřil na vytýčení předpokládané dopadové plochy, sběr vzorků, jejich následnou analýzu a případný objev dalšího kusu tohoto meteoritu. $V$ rámci geologického průzkumu byl v dubnu 2019 objeven detektorem nedaleko nálezu prvního kusu druhý úlomek o váze cca $3.2 \mathrm{~kg}$.

\section{Archeologický výzkum a stručná historie zdejší- ho dolování cínu}

Vzhledem k úzké vazbě místa nálezu obou meteoritů $s$ historickou těžbou a zpracováním cínové rudy u Potůčků uvedeme ve stručnosti některá známá data, vyplývající nejen z literárních pramenů, ale i z výsledků archeologického výzkumu těžebního areálu na Glücksburgu. Tyto informace mohou přispět $k$ diskusi o dopado- 


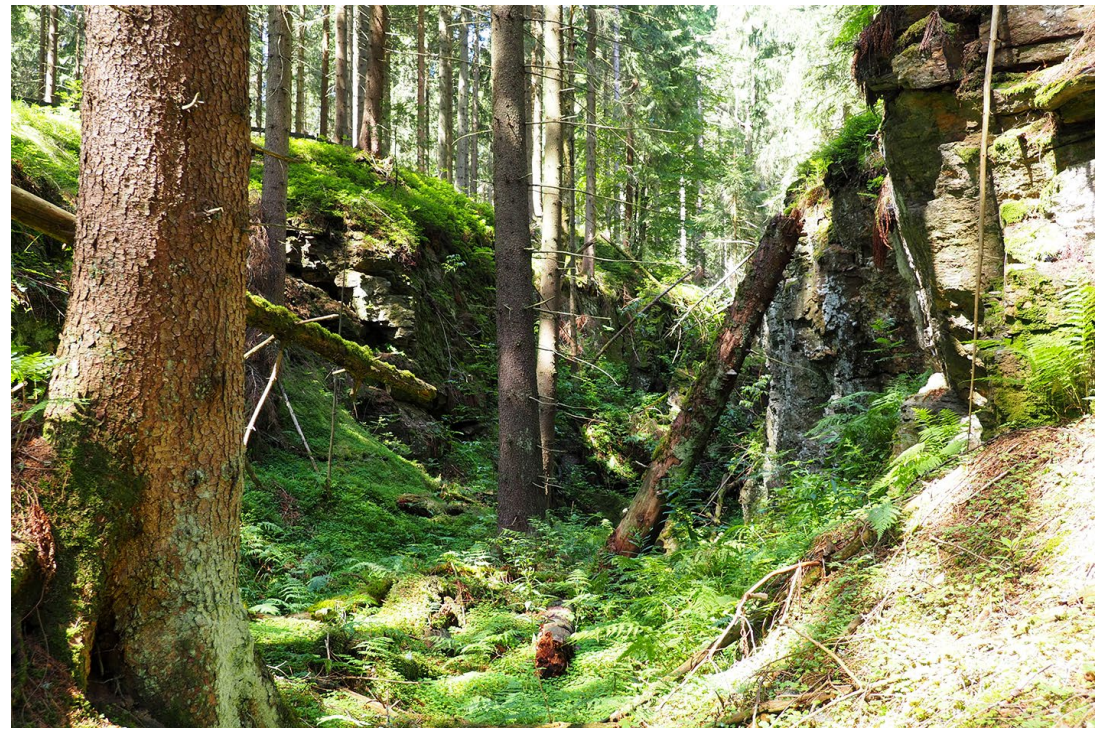

Obr. 1 Rozsáhlý povrchový porub vzniklý v rámci činnosti na dole Naděje v Boha (Hoffnung zu Gott), foto P. Pauliš 2019.

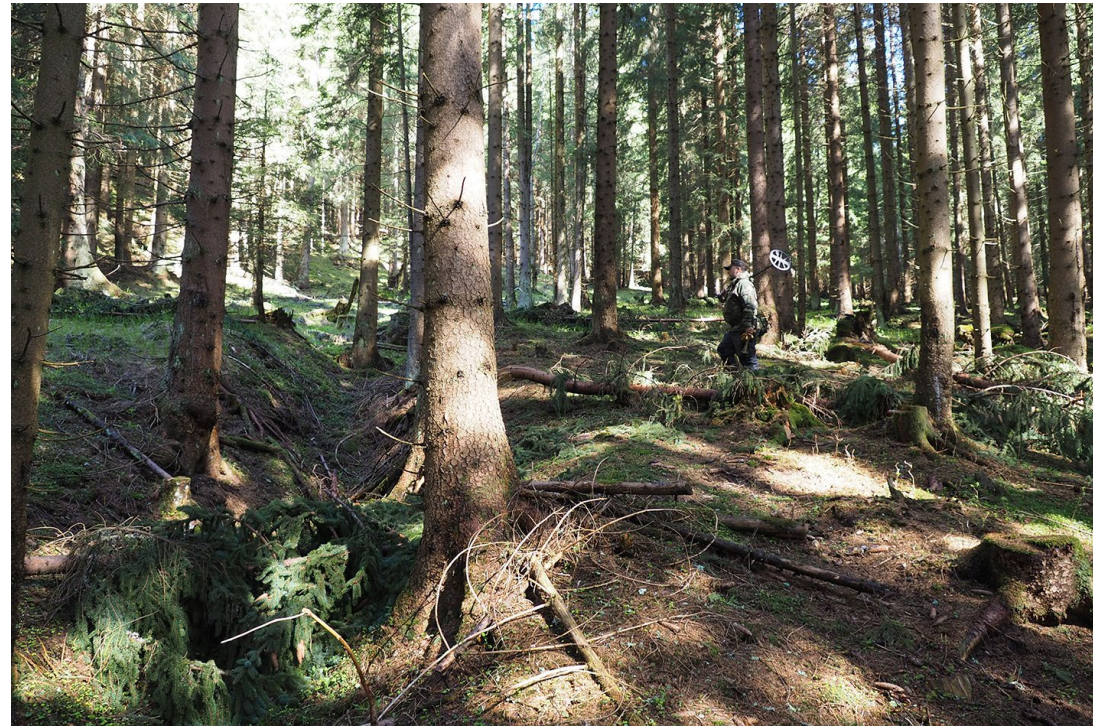

Obr. 2 Lesní terén v okolí nalezených meteoritů, foto P. Pauliš 2019.

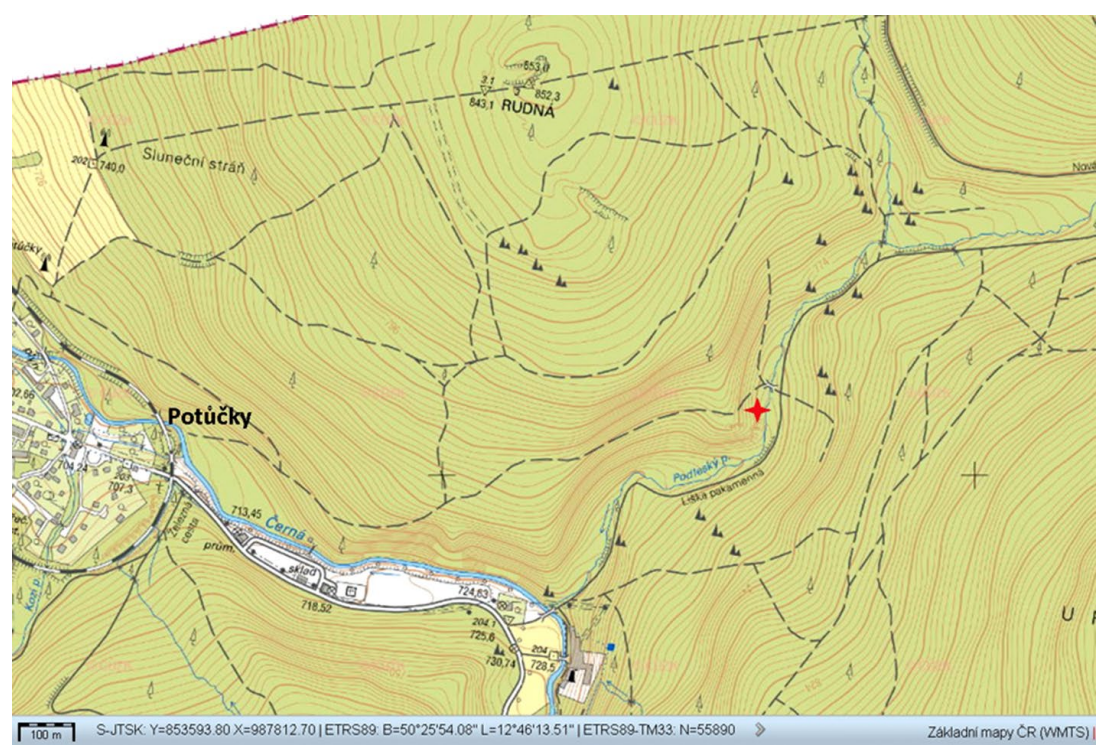

Obr. 3 Plánek naleziště obou meteoritových fragmentů na Glücksburgu u Potưčků. vém stáří meteoritů typu Steinbach. Doly na Glücksburgu (dnes Rudná) byly součástí původně rozsáhlého důlního okrsku Rabenberg, táhnoucího se od Bystrého potoka na sever $\mathrm{k}$ Breitenbrunnu. Práce na primárních ložiscích tu byly zahájeny pravděpodobně v návaznosti na těžbu rozsáhlých náplavů a rozsypů po obou stranách Podleského potoka nejpozději ve 14 . století, pravděpodobně ale výrazně dříve. Ve 14. století, konkrétně k roku 1380, je na Streitbergu dvakrát uváděný opuštěný důl se štolou (Jangl 1975; Fröbe 1994; v širším archeologickém kontextu Malina et al. 2018). Evidentně jde o doklad těžby primárního zdroje anebo alespoň rozsypového ložiska, které mohlo být také těženo štolou. Písemné prameny pro samotnou lokalitu Glücksburg začínají pravděpodobně až ve 20 . letech 16. století, kdy jsou propůjčkami doložené pronájmy rýžovišt' Vilémem z Tetova a na ně navazuje v roce 1530 údaj o velkém počtu dolů na Rabenbergu (Fröbe 1994; Jangl 1967). První propůjčky $v$ blatenské horní knize z let 1534 - 1550 zřetelně naznačuji pokračování staršího provozu. Vazby $k$ velké propadlině dolu Glücksburg a znalost ložiskových poměrů indikuje zmínka o štole k roku 1535 a zmínka o charakteru ložiska „at' je nalezena a zastižena jako peň nebo jako žíla", opět včetně propůjčky nálezné jámy a štoly, Ondřeji Bartelovi v roce 1549 (Jangl 1967). Zmíněný provoz kolem poloviny 16 . století pravděpodobně kulminoval a $\vee 60$. a 70 . letech poklesl, snad i v souvislosti s hraničními spory v letech 1547 - 1588. Zlepšení podmínek následovalo $\vee 70$. letech 16. století. Roku 1579 je v propůjčce Abelu Fickerovi jednoznačně zmíněn důl Glücksburg ve vazbě na velkou propadlinu. Provoz od 70 . let 16 . století do poloviny 17 . století ilustrují i propůjčky dvou štol v letech 1581 a 1593, místa pro tavicí hut' (1581) a též 10 míst pro stoupovny $v$ letech 1579 - 1596. Hut' kurfiřtského náplavního Petera Richtera je uváděna ještě v roce 1638. I přes malé hospodářské výsledky dosažené od poloviny 17. století je zajímavá relace z roku 1730 , která uvádí, že na dole Glücksburg bylo před 100 lety 10 stoupoven, hut', kovárna, vodotěžný stroj, výčep a hospodářské budovy se zahradou a loukami, z nichž jsou ještě (v roce 1730) vidět rozvaliny (Jangl 1967). Situaci na lokalitě koncem 18. století dobře ilustruje i mapa rustikálních pozemků (Hlavová 2016). Na ní je vyobrazeno jak existující stavení 
s obklopující luční enklávou, tak i skalní suk, dva staré odvaly a ruina jakési budovy, odpovídající místu, kde torzo domu evidujeme $v$ terénu i na digitálním modelu terénního reliéfu.

Archeologický průzkum areálu, ležícího pod pásmem dobývek, měl v letech 2017 a 2018 za cíl nalezení archeologicky datovatelných nebo funkčně určitelných nálezů a případně i konstrukcí, souvisejících s osídlením místa anebo se zpracovatelským provozem (Malina et al. 2018; Schneiderwinklová et al. 2018). Již ze zpracovaného digitálního modelu terénního reliéfu $z$ dat leteckého laserového skenování (DMR z dat LLS) byla patrná výrazná koncentrace vodních prríkopů, směřujících ve dvou výškových úrovních do prostoru dobývek dolu Glücksburg. Přiváděná voda zde měla patrně obvyklý dvojí účel: jednak energetický při pohonu čerpacího stroje a také technologický při úpravě rud. Těsně nad skalním sukem jsou v terénu viditelné asi tři až čtyři krátké paralelní př́ikopy, které snad již sloužily k rozdružování narubané rudniny. Patrná je i menší obdélná vodní nádrž. Archeologické nálezy, dokládající úpravnický provoz zmíněný písemnými prameny (10 stoup), tvoří zejména nález kamenné stoupovací botky a tři ploché a dobře usazené kamenné fundamenty (Schneiderwinklová et al. 2018). Všechny tyto nálezy interpretujeme jako doklady stoupového provozu. V DMR jsou rovněž patrné zářezy a odvaly dvou výškově odlišně založených štol.

Nejstarší nalezená keramika patří ještě do středověkého období, respektive dokládá sídelní aktivity ve 13. - 15. století. Jejich vazbu na důlní či zpracovatelskou činnost nedokážeme prokázat, zároveň zde ale neevidujeme jiné typy aktivit než osídlení, těžbu a zpracování rud, se kterými by mohla zjištěná keramika souviset. Nejpočetnější jsou zlomky datovatelné do 16 . až první poloviny 17. století, na temeni skalního suku a $v$ jeho nejbližším okolí je četný i výskyt zlomků okenního skla a kachlů, dokládající obytnou stavbu. Mincovní nálezy z lokality vystihuji obě hlavní fáze využití prostoru. Dva malé groše z let 1579 a 1590 souvisejí velmi pravděpodobně s hornickým provozem, mladší etapa z 18. století, doložená několika mincemi, však již patrně souvisí s hospodářským využitím luční enklávy (Malina et al. 2018).

$\checkmark$ průběhu společného vyhodnocení obou projektů byla zvažována varianta, že oba meteority byly do úpravnického areálu pod dolem Glücksburg přineseny odjinud k případnému hutnickému zpracování v nich obsaženého železa. Tuto hypotézu se nepodařilo ověřit ani vyvrátit, poloha obou kusů však spíše naznačuje, že s nimi nebylo zacházeno jako s potenciálním zdrojem železa.

\section{Nálezové okolnosti a základní popis meteoritů}

Zkoumané území se nachází v údolí Podleského potoka a vrchu po jeho severní straně. Rudná (Glücksburg či Glückburg) je zalesněný vrch při hranici se SRN, s četnými pozůstatky historické těžby cínových, kobaltových a stríbrných rud. Lokalita s rozsáhlými povrchovými dobývkami (obr. 1) a ústími starých štol je protkána vodními kanály s množstvím úvozových cest (obr. 2). Areál na zpracování vytěžené rudy se nachází v logické vazbě na těžbu pod hlavními dobývkami při vodním toku, nad pravým břehem Podleského potoka (Streitseifner Bach), při cestě z Potůčků (Breitenbach) do Podlesí (Streitseifen). Jeho jádro leží na jv. svahu hraniční kóty Rudná (852 m n. m., GPS: 50²5‘45.7“'N, 1245‘32.2“E) (obr. 3).

$\mathrm{K}$ objevu meteoritu došlo při archeologickém výzkumu těžebního areálu, $v$ jehož rámci byla řada nálezů že-

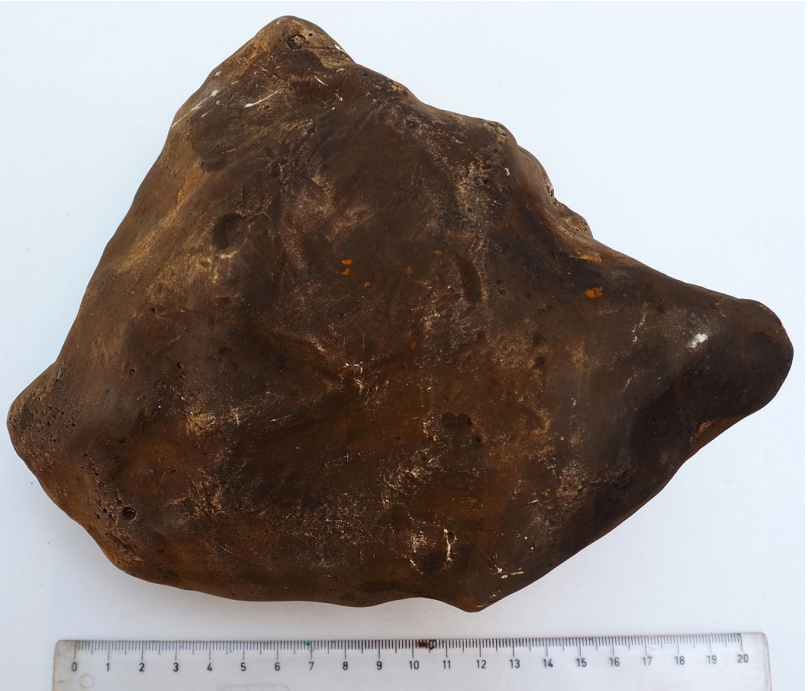

Obr. 4 Sádrový model prvního nalezeného meteoritu s rozměry $19 \times 16 \times 10 \mathrm{~cm}$, foto $P$. Pauliš.

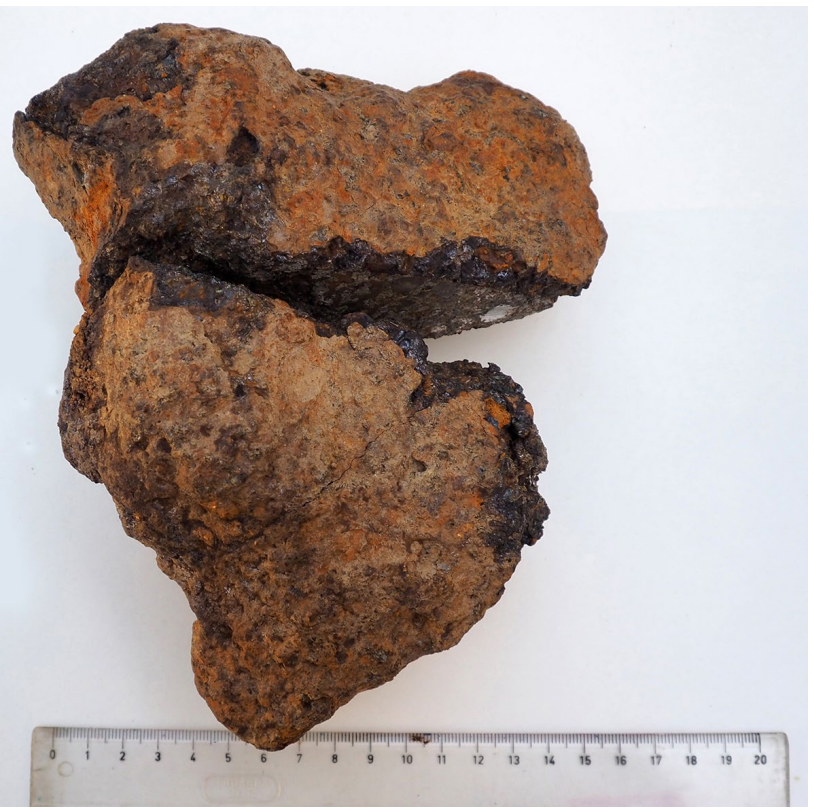

Obr. 5 První nalezený meteorit, dva hlavní fragmenty po rozlomení, foto $P$. Pauliš.

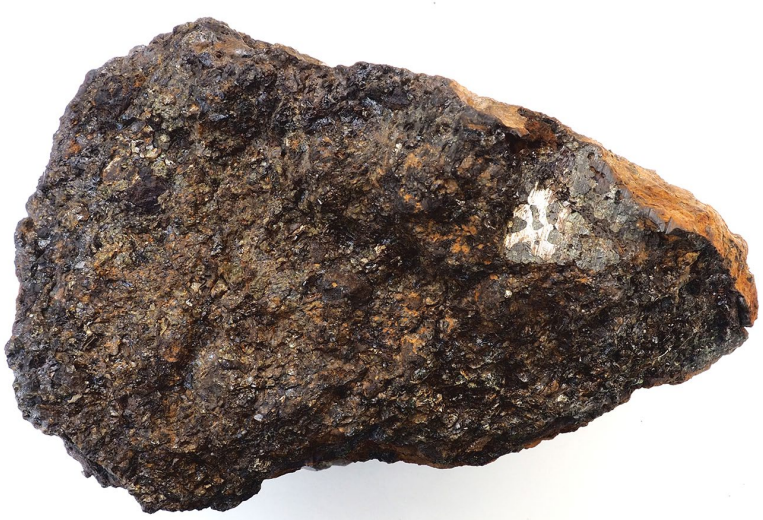

$\begin{array}{lllllllllllllllllllll}0 & 0 \\ 0 & 2 & 3 & 4 & 5 & 6 & 7 & 8 & 9 & 10 & 11 & 12 & 13 & 14 & 15 & 16 & 17 & 18\end{array}$

Obr. 6 Větši fragment prvního meteoritu Steinbach nalezeného na Glücksburgu, foto P. Pauliš. 


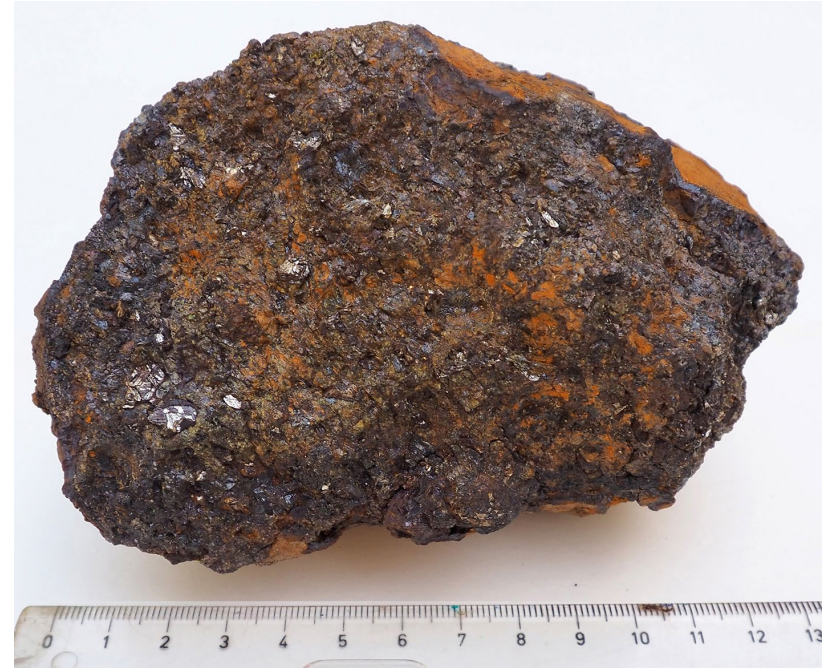

Obr. 7 Menší fragment prvního meteoritu Steinbach nalezeného na Glücksburgu, foto P. Pauliš.

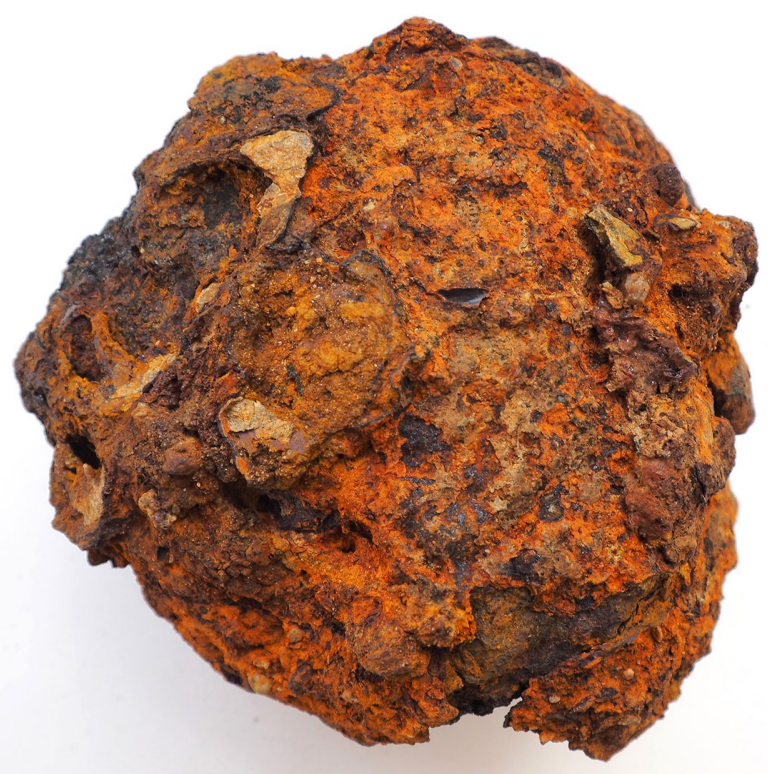

Obr. 8 Celotvar druhého meteoritu Steinbach z Glücksburgu, foto $P$. Pauliš.

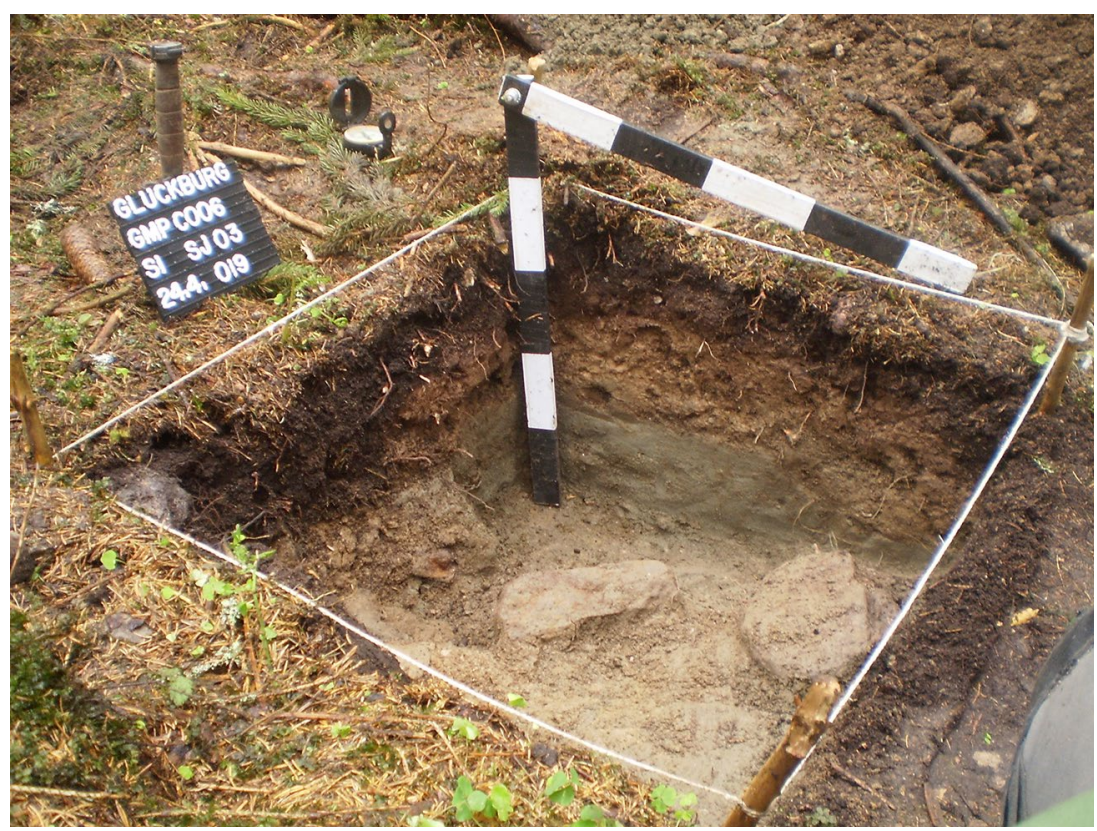

lezných artefaktů (historické kovové nástroje, pásovina, želízka, hutní strusky apod.) podrobena i chemickému a mineralogickému výzkumu. Meteorit nalezl David Černý nedaleko výrazného skalního suku, dominujícího spodní části lokality těsně nad potokem. Vzhledem se tento meteorit pokrytý kůrou oxidačních produktů od běžně nalézaných železných artefaktů nijak nelišil. $\mathrm{Na}$ jeho meteoritický charakter upozornily až jeho texturní a strukturní znaky a v analýzách, které prováděl P. Bohdálek v laboratořích ČGS na Barrandově, také vysoký obsah niklu. Předtím však byl celotvar o rozměrech cca $19 \times 16 \times 10 \mathrm{~cm}$ (obr. 4) rozdělen na dva větší a několik drobnějších částí (obr. 5). Větší fragment o hmotnosti $1840 \mathrm{~g}$ má rozměry $15 \times$ $11 \times 9 \mathrm{~cm}$ (obr. 6), menší fragment s rozměry $14 \times 10 \times$ $9 \mathrm{~cm}$ váží $1705 \mathrm{~g}$ (obr. 7). Při následném geologickém průzkumu lokality byl v dubnu 2019 objeven detektorem nedaleko nálezu prvního kusu druhý meteorit o váze cca $3150 \mathrm{~g}$ a rozměrech $14 \times 12 \times 8.5 \mathrm{~cm}$ (obr. 8) (opět David Černý spolu s Tomášem Malým). Dalším intenzivním detektorovým průzkumem celé předpokládané plochy dopadu se již v průběhu roku 2019 žádný další oddělek objevit nepodařilo. První meteorit byl nalezen $v$ hloubce $30 \mathrm{~cm}$ v místě, které pravděpodobně nebylo součástí hlavního provozního a úpravnického areálu. Meteorit se nacházel ve spodní části okrové hlinito-jílovité vrstvy (C), která je typickým projevem těžebních terénů a zpravidla nasedá na zvětralé podloží. $V$ jádru montánního areálu byla tato vrstva opakovaně datována keramikou do 16. - 17. století. Limonitová krusta, 3 - 7 mm mocná, již obsahovala na spodní části nalezeného meteoritu nálepy drobných valounků křemene, zvětralých slíd a fylitu ze zvětralého podloží.

Druhý meteorit byl lokalizován cca 135 m severním směrem od předchozího na dně malého vodního kanálu, opět na bázi okrové, hlinito-jílovité vrstvy $v$ hloubce 35 $\mathrm{cm}$. I tento kus byl na celém svém povrchu pokrytý kompaktní limonitovou krustou. Nálezová situace byla ověřena sondou GLPC006 s rozměry $60 \times 60 \mathrm{~cm}$ (obr. 9), která ukázala nálezový kontext jako volnou destrukci kamenů uložených $v$ jemně šedavém písčito-jílovitém sedimentu. $\mathrm{Na}$ tuto vrstvu nasedala již zmíněná vrstva $C$, překrytá lesní humózní, tmavě hnědou vrstvou (B) a lesní hrabankou $(A)$. Původně se meteorit patrně nacházel $v$ deponii kamenů na okraji vodního kanálu. Po zániku areálu a destrukci boků kanálu se patrně $s$ částí deponie sesunul na dno. Následně pak byly volné prostory mezi kameny vyplněny jemným písčito-jílovitým sedimentem. Vše pak přikryla vrstva světle hnědé jílovité hlíny a cca $10 \mathrm{~cm}$ lesní hrabanky. S druhým kusem mohlo být $v$ minulosti manipulováno, mohl sloužit, tak jako jiný horninový materiál, při výstavbě sítě kanálů zásobující areál vodou. $\mathrm{K}$ jeho dopadu by tak došlo pravděpodobně již před samotným rozvojem důlního a úpravnického areálu.

Obr. 9 Profil vrstev $v$ sondě S1 v místě nálezu druhého kusu meteoritu na lokalitě Glücksburg se zachycenou destrukcí boční stěny kanálu, foto $D$. Černý. 


\section{Historie objevu a klasifikace meteoritů Steinbach}

Chceme-li se zabývat historií a okolnostmi objevu meteoritického železa z Potůčků (ve veškeré starší literature uváděného pod jménem Breitenbach), musíme začít poněkud ze široka. I když je to meteorit dobře známý ze zahraniční i české literatury již od roku 1863, nepředstavoval by $v$ té záplavě známých meteoritů, pokud by nepocházel z českého území, při povrchním dojmu nic zvláštního. Pokud se jím však začneme zabývat hlouběji, zjistíme, že meteorit z Potůčků je součástí souboru zcela unikátních meteoritů označovaných podle nejstaršího nálezu jako Steinbach, které se zapsaly do dějin mineralogie i meteoritiky. Jejich historie sahá do první poloviny 18. století, a proto není snadné zmapovat a uvést na pravou míru roztroušené literární zmínky a očistit je od chyb a omylů, později na ně navršených, znovu a znovu opakovaných, nesprávných a zavádějících.

$\checkmark$ moderních príručkách a databázích musíme hledat meteorit z Potůčků ve skupině želez IVA a v rámci ní mezi mezi unikátními anomálními IVA meteority, kde je společně s meteoritem Sao Joao Nepomuceno zcela zvláštní s ohledem na (nad)poloviční podíl silikátových fází (včetně $\mathrm{SiO}_{2}$ ) na hmotě meteoritu. Podle strukturní (dnes opuštěné) klasifikace patři meteority Steinbach, respektive $v$ nich obsažené meteoritické železo, mezi oktaedrity (O), na jejichž vyleštěném řezu se po naleptání objeví charakteristické Widmanstättenovy obrazce. Na těchto obrazcích Ize rozlišit průřezy lamel jednotlivých složek tohoto železa - kamacitu a taenitu. Šírka lamel kamacitu je různá, od hrubých (širokých) až po jemné (jemnozrnné), což zohledňuje druhé klasifikační kritérium. $V$ našem príipadě jsou viditelné průřezy lamelami kamacitu široké 0.2 - 0.5 mm, takže železný podíl našeho meteoritu patří mezi oktaedrity jemné (fine), které se označuji zkratkou Of.

Meteority Steinbach $s$ prozatím čtyřmi známými a ověřenými nálezy patři tedy do skupiny IVA-an s dominující silikátovou fází, tvořící až 50 - $85 \%$ objemu. Ta je tvořena zejména pyroxeny (40 - $45 \mathrm{obj}$. \%) a tridymitem (20 - 30 obj. \%). Zbylou asi 1/3 objemu meteoritu tvoří niklové železo (kamacit a taenit) s troilitem (3 - 10 obj. \%) a chromitem (kolem 0.5 obj. \%) (Ruzicka 2014).

Všechny meteority Steinbach jsou charakteristické přitomností tridymitové složky („asmanitu“). Meteority Steinbach patří mezi kamenoželezné meteority též zvané siderolity, obsahující obecně téměř ve stejném poměru meteoritické železo a nekovové minerály, většinou křemičitany („rombické členy řady augitu“, píše Vrba 1896). O unikátním složení těchto meteoritů vypovídá i to, že byly jedinými zástupci tzv. siderofyrů, což byla $v$ minulosti vyčleněná (dnes již nepoužívaná) podskupina siderolitů (Tschermak 1883).

Doposud známé meteority Steinbach, o kterých tu je podrobněji pojednáno, jsou čtyři: Grimma/Gotha, Steinbach, Rittersgrün, Breitenbach/Potůčky a konečně se zmíníme i o pátém, suspektním meteoritu ze sbírky Ignáce Borna, známém od roku 1772 (Born 1772). Všechny byly nalezeny na různých místech a v různé době, všechny patří do jedné speciální skupiny a pocházejí z jednoho zdroje a společného hypotetického pádového pole. Tuček (1981), když zmiňuje naleziště meteoritů Steinbach, píše, ale bez upřesnění zdroje, o šesti nálezech: „Místa nálezù jsou na vrcholech obecného trojúhelníka a jsou od sebe vzdálena pouze 4 - $9 \mathrm{~km}$. Údajně tu bylo nalezeno celkem asi 6 kusů meteoritů, vesměs se vzácným, zajímavým, velice príbuzným mineralogickým složením".
Hojná synonyma tohoto meteoritu vyjadřující jména míst nálezů (někdy chybná) se v př́slušné literatuře hromadí od nejstarších dob: Grimma, Gotha a Neuhof (Naunhof), Sachsen, Steinbach, Eibenstock, Johanngeorgenstadt, Rittersgrün, Breitenbach (což jsou od roku 1948 dnešní Potůčky). Tučně jsou vyznačena místa čtyř více či méně doložených nálezů. Pomineme-li Grimmu, mohly by se doložené nálezy nacházet na hypotetickém území dopadu meteoritického „deště“. Potůčky (Breitenbach) leží na hranici se Saskem, kde sousedí s městem Johanngeorgenstadt, u něhož je obec Steinbach, odkud je vzdušnou čarou asi $4 \mathrm{~km}$ do Potůčků. Z místa nálezu největšího železa, z Rittersgrünu, je to cca $10 \mathrm{~km}$ vzdušnou čarou do Potůčků i do Steinbachu. $V$ tomto prostoru na saském území leží ale také obce Breitenhof a Breitenbrunn (k poslední administrativně patř́ Rittersgrün), podobného jména jako Breitenbach a mohli bychom spekulovat o případné záměně, pokud by se ve zprávě o nálezu meteoritu Breitenbach nepsalo jasně „v Čechách“. Z uvedeného pohraničního území ovšem výrazně vybočuje nejdříve známé údajné místo nálezu železa u města Grimma (an der Mulde/na řece Muldě), které je odsud velmi vzdálené a o němž se zmíníme vzápětí.

Váha všech těchto želez, podle lokality souhrnně označovaných Steinbach prípadně Sachsen (Partsch 1843), činila ve sbírkách v roce 189781.786 kg (Wülfing 1897).

Grimma: údajně velká masa (nebo snad masy?) neznámé původní váhy, z níž je dnes zachován jediný kus o hmotnosti 893 g (917 g podle Wülfinga 1897), nacházející se pouze v Gothě.

Steinbach: z konkrétní obce Steinbach není známo nic, ale Steinbach byl jakýmsi centrem rozsáhlých rýžovnických prací, odkud nálezy pocházely. Odhadem šlo o exemplář váhy asi $\mathbf{1} \mathbf{k g}$ (?), který byl $v$ podobě odřezků a úlomků rozptýlen v řadě sbírek a je dnes velmi vzácný. $\checkmark$ současnosti například Natural History Museum v Londýně vlastní pouze $1.7 \mathrm{~g}$.

Rittersgrün: původní váha 86.5 kg (173 pfundů); hlavní kus ve Freibergu v Sasku, v roce 1897 (Wülfing 1897) vážil 55.56 kg; K. k. naturhistorisches Hofmuseum ve Vídni má hlavní kus o hmotnosti 1342 g, celkem vlastní 1815 g (Brezina 1895); Národní muzeum v Praze mělo v roce $18979 \mathrm{~g}$ a v roce $196676 \mathrm{~g}$ (Tuček 1968) (obr. 10); $v$ Brně měl v soukromé sbírce Josef Melion $5 \mathrm{~g}$ (Wülfing 1897).

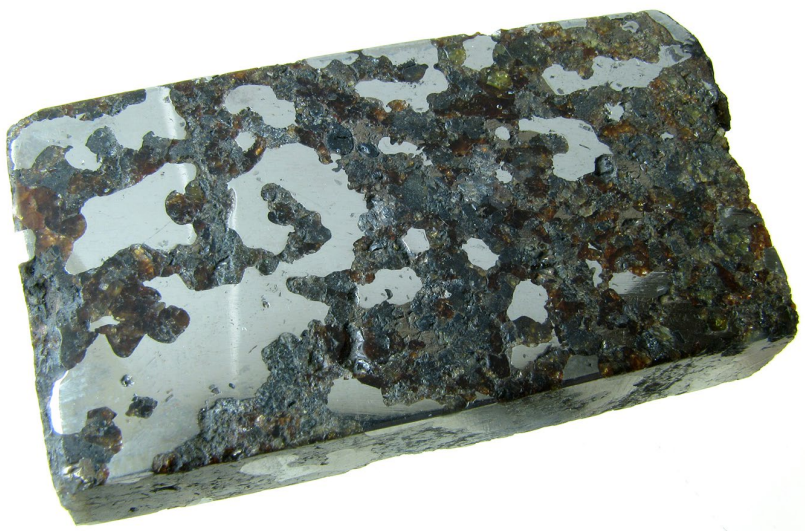

Obr. 10 Vzorek meteoritu Steinbach z Rittersgrünu o rozměrech $60 \times 28 \times 11 \mathrm{~mm}$ a hmotnosti $73 \mathrm{~g}$ ze sbírky Národního muzea v Praze (č. P1M35), foto D. Velebil. 
Breitenbach: pưvodní váha odhadem $10.5 \mathrm{~kg}$; Hlavní kus o hmotnosti $7057 \mathrm{~g}$ byl v Londýně (Wülfing 1897). K. k. naturhistorisches Hofmuseum (Wien) vlastnilo $64 \mathrm{~g}$ (Brezina 1895). V současnosti Natural History Museum v Londýně eviduje ve sbírce meteoritů hlavní část o hmotnosti $6230 \mathrm{~g}$ a fragment $689 \mathrm{~g}$ těžký (Graham et al. 1985).

Můžeme tedy konstatovat, že meteority Steinbach, zastoupené $v$ mnoha sbírkách, tvoří převážně kusy získané z velkého balvanu nalezeného u Rittersgrünu, z vlastního Steinbachu se zachovalo minimum, zatímco z lokality Breitenbach (Potůčky) existují, pokud je známo, pouze vzorky uložené v Londýně a ve Vídni.

\section{Grimma (Gotha)}

Další zprávy by se měly týkat meteoritu, který je označován jako Grimma či Gotha. Je to nejstarší železo typu IVA-an (Steinbach), dochované ve sbírkách. Jeho existence byla poprvé zmíněna v roce 1824 a bývá spojováno se dvěmi historickými událostmi. První se měla odehrát v roce 1164 a jejím výsledkem by mohl být vznik dosti rozsáhlého pádového pole meteoritických želez bez bližší lokalizace, ale bylo to v "Míšeňsku“, nebot' citujeme z Fabriciovy „Míšeňské kroniky“: „Deště železné. 1164. Kolem Letnic za velké bouře pršení železa zaznamenal Sarctorius"(Fabricius 1597, překlad M. Bohatý). Matthaeus Sarctorius (†1609), od nějž Fabricius záznam převzal, byl superintendantem $v$ Míšni a Fabriciovým současníkem (Weisbach 1876).

A druhá zpráva, tentokrát o pádu a nálezu (1540 1550?) jediného velkého železa: „Jsou [lidé], kteři tvrdí, že $v$ Neuhofských lesích u Grimmy spadla ze vzduchu železná masa podobná strusce, a vyprávějí, že ta masa měla [hmotnost] mnoho liber, takže nemohla být z toho místa odnesena kvưli váze ani odvezena vozem kvưli neprístupné poloze. Stalo se to ještě před saskou občanskou válkou, která byla vedena mezi agnátskými (= přibuznými) panovníky" (Fabricius in Gesner 1565, překlad M. Bohatý). Ta saská občanská válka byla zřejmě ona, která proběhla $v$ rámci tzv. šmalkaldské války (1546 - 1547). Totéž opakuje Petrus Albinus o něco později, ne zrovna přesně: „Velký kus železné rudy u Grimmy nalezen. Velký kus železné rudy / která vyhlížela / jako struska / a byla nalezena v lese u Grimmy / a nikdo nevěděl, odkud se tam vzala" a zároveň doslova cituje výše zmíněného Fabricia (1565). Z původní předlohy in syluis Neuhofianis prope Grimam ( $v$ lese neuhofském = z lesa u vesnice Neuhof u Grimmy) má však Albinus jen bey Grimme; v marginálii bey Grimm / u Grimmy (Albinus 1590a,b).

Jako lokalizaci máme tedy zatím jen historický územní celek Míšeňsko, předchůdce Saska, kam patřila Grimma, ale i krušnohorské pohraničí. Zda výše zmíněná kronikářská událost (1546 - 1547?), o níž ale, snad kromě přesného vročení, není třeba pochybovat, má souvislost s později náhodně nalezenými železy, není jasné.

Vzhledem k tomu, že je toto železo po všech stránkách stejné jako Steinbach, by uváděné místo nálezu u Grimmy bylo velmi vzdálené od ostatních tří lokalit. Existuje proto neprokázaná domněnka, že se o dnešní město Grimma nemuselo jednat, ale šlo o jiné místo v bývalém Míšeňsku, osídlené v minulosti slovanskými Lužickými Srby. Došlo se k tomu tak, a to se dostáváme na tenký led toponomastiky, že kořen slova "grim“ je údajně slovanský (starosrbský) a označoval prohloubeninu v terénu, vyplněnou vodou a zamokřenými lukami. Tedy ne obec, ale místo v krajině (mokřad), které se tudíž mohlo nacházet kdekoliv (Eichler, Walther 2007). Musíme se tedy smírit s tím, že meteorit pojmenovaný po Grimmě, vzdálené cca 125 km od Potůčků, který je ve sbírce v Gothě, nemusí pocházet nutně z Grimmy. Známý průkopník meteoritiky Ernst Florens Friedrich Chladni (*1756 - †1827) tyto údaje později svým způsobem shrnuje, ale zároveň sem vnáší další otazníky. Tak se například zmiňuje o tom, že starší komentátoři, jako byl Georgius Agricola (*1494 †1555), kladou pád a nález velké masy železa k neexistující obci Neuholem, což je nejspíš Neuhof mezi Grimmou a Lipskem. Jak se z původní obce „Neuhof“ stal u Chladniho „Naunhof" nevíme, ne-li tiskovou chybou, pak snad že se v okolí města Grimmy žádný Neuhof nevyskytuje, zatímco Naunhof hned dvakrát (Chladni 1808, 1819). Jeden z nich leží mezi Grimmou a Lipskem (10 km sz. od Grimmy). Jiný Naundorf u Schmiedebergu je částí krajského města Dippoldiswalde na severním svahu východního Krušnohoří, jižně od Drážd’an. Je zde také přibližné vročení pádu „před polovinou 16. století“, které Chladni zřejmě odvodil z data Fabriciovy publikace (Fabricius in Gesner 1565), prípadně proto, že ho zmiňuje Agricola a najdeme zde také hrubý odhad váhy „několik pfundü“ (1 Pfund $=0.5 \mathrm{~kg}$ ).

Železo Gotha (resp. Grimma či Naunhof) bylo tedy individuum, nikoliv úlomek a do sbírky $v$ Gothě se dostal asi v roce 1724 (Stromeyer 1824). Friedrich Stromeyer ( ${ }^{*} 1776$ - †1835), který v roce 1824 publikoval svoje analýzy olivínu a jeho odrůdy chryzolitu, včetně meteoritických, analyzoval i několik úlomků tohoto železa a také několik gramů v něm obsaženého „olivínu“. Stromeyer už tehdy poznal, že nejde o olivín, ale nějaký dosud neznámý křemičitan - „Magnesium-Trisilikat“, který měl specifickou hmotnost 3.276, což koresponduje s hodnotou 3.238, kterou později pro bronzit (enstatit) z meteoritu Potůčky udává Story-Maskelyne (1871). Dalším pozoruhodným Stromeyerovým zjištěním bylo, že meteorit Grima/Gotha vedle křemičitanů obsahuje i oxid křemičitý, tedy křemen (Stromeyer 1824), pozdější tridymit.

K samotnému spornému nalezišti se později vyjadřují další badatelé:

„Je ale nepochybné, že Schönbergưv meteorit (Grimma/Gotha), Steinbach a Rittersgrün (Breitenbach/ Potůčky nebyl ještě znám) patři jednomu a témuž pádu, a sice pravděpodobně železnému dešti, který se odehrál o Letnicích $1164 v$ Sasku a při kterém jeden meteorit spadl $i$ do města Míšně“ (Buchner 1863). Další informaci poskytl Breithaupt (1862b):

„Meteorit ze sbírky v roce 1761 zemřelého saského vrchního báňského hejtmana Kurta Alexandra von Schönberga se $v$ současnosti nachází ve vévodské sbírce $v$ Gothě. Tento meteorit je samostatná masa, nikoliv teprve na Zemi od jiné oddělená. A tehdejší vědecky vzdělaný von Schönberg by neetiketoval kus jako ,jak byl nalezen na poli“, kdyby byl nalezen na nějakém speciálním hornickém místě (jedno takové bylo cínovcové aluvium u Steinbachu). Nejpravděpodobnějši je, že byl tento kus nalezen na poli u Freibergu nebo na některém z von Schönbergových statků Oberschöna, Börnichen, Wingendorf, Linde, Wiese, které leží blízko Freibergu a které vlastnil otec jmenovaného Schönberga. Výše jmenovaný Schönberg onemocněl ve Freibergu a v Oberschöna zemrel".

Na základě těchto historických zpráv o pádu železných meteoritů v Míšeňsku, známých pod jmény Grimma respektive Neuhof nebo Naunhof (literární nález velkého železného meteoritu) nebo Gotha, je pravděpodobné, což již předpokládal Chladni (1819), že pocházejí jako ostatní železa z okolí Johanngeorgenstadtu. Dnes se toto 
železo nachází ve sbírce na zámku Friedensstein v Gothě a původně, tj. od dob, kdy na něj bylo upozorněno $v$ tisku a kdy vážilo „několik pfundư“, tj. několikrát $0.5 \mathrm{~kg}$, z něj postupně začalo ubývat, protože už v roce 1809 daroval malý odřezek hlavního (?) exempáře o váze $7 / 32$ lotů (cca $110 \mathrm{~g}$ ) vídeňskému dvornímu muzeu pan von Schlotheim z Gothy (Partsch 1843). Ještě za Stromeyera (1824) a Wülfinga (1897) vážila ukázka $917 \mathrm{~g}$, dnes je to 893 gramů (Anonym 2009).

\section{Steinbach}

Meteoritické železo, tentokrát již jednoznačně z oblasti blízko našich západních hranic, zmiňuje poprvé učený teolog (jinde báňský rada) Johann Friedrich Stoy (*1700 - †1760), který byl asi první, kdo v Berlíně viděl a v roce 1748 popsal železo, které Marggraf (recte Andreas Sigismund Marggraf, *1709 - †1782) nalezl před několika lety na haldě železné rudy u steinbašských rýžovisek mezi Eibenstockem a Johanngeorgenstadtem. Marggraf měl řadu let tento kus ve sbírce, aby při pokusu odrazit malý kousek pro jistého pana Holzendorfa zjistil, že se nedá snadno rozbít. Stoy nakonec malý kousek získal a popisuje ho jako složený $z$ jakési hnědé tkáně tvořené železem, které celé těleso drží pohromadě. Hmota železa je buněčnatá, meziprostory neboli buňky jsou vyplněny průhledným či neprůhledným hnědým granátem, který je také, ale slaběji než železo, přitahován magnetem. V květnu a červnu téhož roku (1748) Stoy prohledával haldy železné rudy u Steinbachu, ale neměl tolik štěstí jako pan Marggraf (Stoy 1751).

Podobná slova čteme též u Johanna Georga Lehmanna (*1765 - †1811): „Existence ryzího železa v přírodě je většinou popírána a já potvrzuji, že i já jsem donedávna patřil do počtu popíračů. Až sám neúnavný zdejší (= berlínský) chymikus Markgraf mne z omylu zcela vyvedl. Značně velký kus s dvojvrstvým povlakem (krustou) na povrchu, který dotyčný vlastní z Eibenstocku v Sasku, musí o tom jednoho každého očividně přesvědčit. Je to hnědá železná ruda, ve které sedí velmi mnoho velkých kusů ryzího železa, které přitahují magnet a jež se ohýbají tam a sem jako drát a nechají se kovat pod kladivem, $v$ ohni se taví jako čisté železo a jeví tedy skutečné vlastnosti ryzího železa. Musel jsem tedy, z mého pouhého puzení k oponování, ustoupit a přestat trvat na svém starém mínění. Zkrátka, jsem už přesvědčen, že existuje rostlé ryzí železo“ (Lehmann 1751). Identické železo z Eibenstocku, které popisuje Lehmann, měl zastoupené exemplářem ve své sbírce M. H. Klaproth (Klaproth 1803).

A do třetice nacházíme prakticky totéž s několika podrobnostmi navíc ve spisu Christiana Gottlieba Pötzsche (*1732 - †1805), který, aby byl přijat za mimořádného člena pražské Královské české společnosti nauk, určil pro její Spisy (Schriften der Königlichen böhmischen Gesellschaft der Wissenschaften) svoji práci o výskytu ryzího železa v přírodě, včetně meteoritů. Pötzsch žil ke konci života $v$ Drážd'anech a kromě členství $v$ různých vědeckých společnostech pracoval jako úředník a byl nadšený prírodovědec, vlastnil i mineralogickou sbírku o cca 5000 kusech, kterou ještě za života prodal polskému kancléři Kollontayovi. Pötzsch byl skutečně $v$ roce 1803 prijiat za mimořádného člena Královské české společnosti nauk, bylo mu však doporučeno, aby svůj spis pro velký rozsah vydal samostatně, což učinil (Pötzsch 1804). V něm se píše: „Před téměř 60 lety (= kolem roku 1750) objevil ředitel Marggraf prí cestě po saském Krušnohoří na haldě železné rudy u steinbašských železáren
(Steinbacher Eisenwerke) mezi Eibenstockem a Johanngeorgenstadtem vzorek buněčnatého utváření, se svými oběmi korami (beiden Saalbändern) o čemž dřive podal zprávu bývalý tamní báňský hejtman Stoy. Meziprostory neboli buňky železa byly vyplněny zčásti průhlednými, zčásti neprůhlednými zelenými a hnědavými granáty. Vzorek měl ve sbirce také M. H. Klaproth".

Takže zde máme poprvé meteorit s lokalitou, asi dosti širokou a neurčitou, Steinbach a jeho další synonymum Eibenstock (Eibenstock - Steinbach, vzdušnou čarou 12 km), poprvé zmíněnou $v$ roce 1751.

Podle Chladniho bylo toto železo nalezeno na haldě železné (?) rudy u rozsáhlých steinbašských rýžovišt' (na cínovec) mezi Eibenstockem a Joganngeorgenstadtem. O váze ani o osudu tohoto železa Steinbach se zde ani jinde nic bližšího nepíše, jen že hlavní kus původně vlastnil chemik Marggraf v Berlíně, kde mohl teoreticky zůstat (Chladni 1819). Marggrafovu sbírku získal lékárník a chemik Martin Heinrich Klaproth a s ní se meteorit mohl dostat později na berlínskou univerzitu a posléze (zda celý?) do Vídně.

Paul Partsch ke Steinbachu řadí i některé kusy z Dvorního kabinetu minerálů ve Vídni, označené chybnými nalezišti. Byl to malý kousek $9 / 32$ lotu (140 g) s lokalitou „Senegal“, dále naleštěný kousek 14/32 lotu (asi 220 g) získaný výměnou s univerzitou v Berlíně a pocházející z bývalé Klaprothovy sbírky a jak píše Partsch, původem asi od Ignáce Borna. Vzorek měl údajnou a chybnou lokalitu Tábor v Čechách, spočívající v omylu I. Borna, o kterém se ještě později zmíníme. A konečně velký fragment meteoritického železa rozř́znutého na dva kusy (1 pfund, 14 lotů +16 lotů $/ 720 \mathrm{~g}+250 \mathrm{~g}$ ), označený chybně jako „Norwegen“ (Partsch 1843). Ten poslední byl uveden již roku 1769 v Stieglitzově sbírce jako „ryzí železo se zrnitým křemenem a nažloutlým fluoritem z Norska" (Stieglitz 1769). S podobným popisem se později objevuje tento kus v seznamu mineralogické sbírky Tereziánské akademie ve Vídni: „Ryzí, zubatě a cuckovitě vyrostlé železo se zrnitým křemenem a žlutavým fluoritem. Z Norska" (Anonym 1776).

U nás tyto údaje shrnuje Jan Svatopluk Presl ( ${ }^{*} 1791$ - †1849), který rozeznává tzv. „Železo powětrné bublinaté" ze sedmi lokalit, mezi nimi: 5) Kawal mezi Eibenstockem a Johangeorgenstadtem w Sasku nalezený; 6) Kawalek dle domněnj z Norwegu v c. k. přjrodowně wjdeňské chowaný; 7) Kawal několik liber těžký v Gothě (Presl 1833). Poznamenejme jen na okraj, že J. S. Presl nebyl zdaleka přesvědčen o vesmírném původu meteoritů a ještě $v$ této době je kupodivu považoval za zemské výpary a prach, ztuhlé $v$ atmosféře, tím pádem ztěžklé a vlastní vahou spadlé na zemský povrch. Podle Wülfinga (1897) se toto Stieglitzovo železo „Norwegen“ ve sbírce vídeňského muzea již nenachází. Porůznu se opakující „žlutý fluorit“ bude jistě nějaký silikát a „zrnitý křemen“ by mohl být tehdy ještě neznámý tridymit (,asmanit“).

$O$ jaký druh naleziště, $z$ něhož se meteorit pravděpodobně dostal na haldu železné rudy, se jednalo? Při rozsáhlém rýžování cínovce na sekundárních nalezištích na saské (např. steinbašské a eibenstocké rýžovnické pohoři / revír, zejména na potoku u obce Steinbach a u přilehlé rýžovnické osady Sauschwemme, kde rýžování propírání probíhalo nejméně do roku 1843 a dodnes po něm zbyly až $10 \mathrm{~m}$ vysoké haldy jalového štěrku) i české straně Krušných hor (např. Platten - Horní Blatná, Rolava) se na rozsáhlých plochách promývaly náplavy často až na skalní podklad. Pozornosti rýžovníků neušlo nic, co 
by šlo využít. Vedle kasiteritu, odkládali k dalšímu využití i křemen a vše, co pokládali za užitečné. A to včetně různých železných rud, takže nápadně cizorodé kusy železa nepochybně odložili (Charpentier 1778).

Willim Smith Clark (*1826 - 1886†), pozdější profesor na Massachusetts Agricultural College (dnes University of Massachusetts Amherst), si v roce 1851 „odskočil“ na univerzitu v Göttingen, kde studoval botaniku a chemii a $v$ následujícím roce dosáhl doktorátu filozofie $v$ oboru chemie. Ve svém inauguračním spisu se zabýval meteority, tj. převážně z literárních údajů zkompiloval popis 60 železných meteoritů, včetně některých z Česka (Loket/ Elbogen, Bohumilice/Bohumilitz, Broumov/Braunau) a dnešního Slovenska (Orava/Magura, Lenártov/Lenarto). Jako čtvrtý $v$ řadě zde popisuje meteorit "Saxony“ (což mohl být $v$ roce 1852 pouze Steinbach), složený ze železa a „olivínu“ („olivenoid mineral“), nacházející se ve sbírce vídeňského muzea s chybnou lokalitou „Norwegen“. Na tabuli II (Plate II) nacházíme i vyobrazení jeho rezné plochy (s lok. Saxony), převzaté podle autora $z$ „Haidingerovy Mineralogie z roku 1845“ (Clark 1852). V Haidingerově „Příručce určovací mineralogie“ se však takové obrázky nenacházejí, takže jejich pưvod je nám neznámý (Haidinger 1845).

\section{Rittersgrün}

Jméno pochází od naleziště, kterým je Rittersgrün (vlastně Ehrenzipfel), obojí patři od roku 2017 k obci Breitenbrunn, která se nachází těsně u česko-německých hranic. Na rozdíl od předchozích lokalit zde máme k okolnostem nálezu tohoto největšího známého železa IVA-an (Steinbach) více podrobností.

C. Winkler (1878) jej charakterizoval takto: „Jeden z nejkrásnějších a nejzajímavějších meteoritư, $k$ tomu též nejtěžši a s největši reznou plochou, je železný meteorit od Rittersgrünu v saském Rudohoři. Podle záznamů, za něž vděčíme $p$. hornímu radovi prof. dr. A. Weisbachovi, ukazuje se $v$ ohledu jeho mineralogického složení velká shoda s meteority ze Steinbachu v Rudohoří a Breitenbachu v Čechách a protože zmíněná tři naleziště leži asi jednu míli od sebe, je odůvodněný předpoklad, že se zde jedná o jeden a týž pád meteoritư" (překlad M. Bohatý). A. Breithaupt, který meteorit získal, a tím zachránil a uvedl do literatury, je na rozdíl od $A$. Weisbacha zmíněn ve Winklerově důležité práci, $\mathrm{k}$ niž se ještě dostaneme, jen okrajově.

August Breithaupt (*1791 - †1873), profesor Báňské akademie ve Freibergu píše geologu v Berlíně a od roku 1875 řediteli berlínského muzea H. E. Beyrichovi (*1815 - †1896) 17. 10. 1861: „Na cestě po vnitrozemí během našich posledních hlavních prázdnin (= prázdnin Báňské akademie ve Freibergu) jsem št’astným způsobem vypátral již před 14 lety nalezenou a 173 pfundů/liber (86.5 kg) těžkou masu železa, a sice u nálezce, jednoho sedláka z Rittersgrünu u Schwarzenbergu. Jde o vynikající meteorit k nerozeznání podobný Pallasovu železu od Jeniseje na Sibiři. Mưj meteorit obsahuje nejméně 1000 individuí peridotu. Nechal jsem jej fotografovat a zhotovit model, a tento týden bude také ukončená chemická analýza (prováděl A. Weisbach a dr. C. Rube). Nyní chci nechat odřiznout asi 30-40 pfundù a pak jimi podělit veřejné instituce. Do Berlína chci také věnovat 1 pfund jako dokladový kus a jeden omalovaný sádrový model." (Breithaupt 1861). $\checkmark$ další práci Breithaupt (1862b) sděluje: „Meteorit měl střední průměr $43 \mathrm{~cm}$ ( $v$ nejširším místě $46.43 \mathrm{~cm}$ ), výšku $34.52 \mathrm{~cm}$ a tloušt'ku $30.95 \mathrm{~cm}$; jeho forma je nepravidelná a váži $86.5 \mathrm{~kg}$. Meteorit je pokryt milimetr tenkou vrstvou rzi, tvořenou nikl obsahujícím vodnatým oxidem železa, pod níž je zřetelně rozeznatelná, jako pergamen tenká vrstva „Brandrinde“ (ožehnutá, spálená krusta), složená z magnetitu (Magneteisenerz). Hlavní složkou meteoritu je peridot a na uraženém a prileštěném místě se ukázaly Widmanstättenovy obrazce, jako důkaz meteoritického původu železa. Samotné železo je trojí (tzv. Reichenbachova trias): Fülleisen (výplňové železo, plessit, Ni-chudé železo, vyplňuje mezery mezi deskami taenitu), následují lišty „Balkeneisen“ (trámcové železo, kamacit, Ni-bohatší železo), jevící se jako prưřezy desek železa v podobě lišt, zodpovědných za Widmanstättenovy obrazce a konečně lupínky silně lesklého „Bandeisen“ (páskové železo, taenit, $\mathrm{Ni}$ - nejbohatší). Vnitřek meteoritu sestává prevážně z peridotu, jenž je obklopen soudržným, cuckovitě a větevnatě formovaným železem. $V$ peridotu je vtroušeno také velmi mnoho pyrhotinu (= troilitu) do velikosti velkého hrachu. Schreibersit jsem našel jen ve stopě a přichází zde i další minerál, jehož výzkum není ještě ukončen" (snad pozdější tridymit?). „Rittersgrünnské železo si zaslouží vyčerpávající popis a monografii mám hotovou, zbývají jen $k$ ní patřicí kresby, z nichž dvě představují vnějši podobu, jedna největší řeznou plochu $v$ přirozené velikosti a dalši Widmanstättenovy obrazce. Řezná plocha takové velikosti ještě neexistuje u žádného meteoritu a mistrovsky ji provedl kamenořezač pan Klement ve Vídni".

Pod vedením A. Breithaupta bylo provedeno také důkladné rozřezání meteoritu. Hlavní řez na dvě poloviny ( $v$ místě maximálního průřezu balvanu, aby byla zachována i druhá vnější plocha, na níž se „spatřuje podoba hlavy Iva s očními důlky a nosem") provedl jistý pan Clement ve vídeňském Dvorním kabinetu minerálů, práce trvala dva měsíce a spotřebovalo se při ní 14 ocelových kotoučů a dva centýře (asi $100 \mathrm{~kg}$ ) smirku. Větší odřez vážil 110 pfundů (55 kg v ceně tehdejších 18000 marek), menší kus, 48 pfundů $(24 \mathrm{~kg})$, byl rozřezaný na jednotlivé díly. Těžší odřez zůstal ve sbírce Báňské akademie ve Freibergu, z menšího obdržel Breithaupt 18 pfundů $(9 \mathrm{~kg})$, Vídeň 9 pfundů $/ 4.5 \mathrm{~kg}$ (nesla náklady s řezáním ve výši 200 tolarů) a darem po jednom pfundu Drážd’any, Berlín, Petrohrad. 14 pfundů $(7 \mathrm{~kg})$ přenecháno Královskému skladu minerálů ve Freibergu (Königliche sächsische Mineralalien-Niederlage), kde je rozřezali na 86 kusů na prodej (2 tolary za lot = za cca $16 \mathrm{~g}$ ) pro další zájemce (Winkler 1878). Což později C. Winkler doplnil: „Rozřezání meteoritického železa se provedlo ve Vídni a byla to vysoce obtížná a nákladná práce, která si vyžádala plné dva měsíce. Největši rezná plocha s obvodem $118 \mathrm{~cm}$ zaujímá $1104 \mathrm{~cm}^{2}$... Kus o váze 9 kg, který se nacházel $\checkmark$ Breithauptově vlastnictví, byl po jeho smrti dále rozřezán a přešel na K. K. Mineralien-Niederlage ve Freibergu a na C. F. Pecha v Berlíně" (Winkler 1878). Meteorit byl tedy záhy po nalezení poměrně drasticky rozčleněn a jen $k$ prodeji se $z$ něj 18 kg postupně nařezalo na desítky destiček, což také vysvětluje jeho poměrně časté zastoupení ve sbírkách.

Dr. C. Rube (jinde Rübe) analyzoval meteorit jako celek kvalitativně i kvantitativně a došel u složení železa k následujícímu výsledku: $87.31 \% \mathrm{Fe}, 9.63 \% \mathrm{Ni}, 0.58$ \% Co, $1.37 \% \mathrm{P}, 0.25 \% \mathrm{Ca}, 0.15 \% \mathrm{Mg}, 0.98 \% \mathrm{SiO}_{2}=$ $100.27 \%$ (Breithaupt 1862a, b; Rube in Weisbach 1876).

Breithaupt se $v$ této době stále domníval, že hlavní komponentou meteoritu je peridot (olivín), bezpochyby šlo ale o enstatit („bronzit“). To ovšem zjistili až jeho ná- 
sledovníci (A. Weisbach, jenž svou práci podepsal jen iniciálami a C. Winkler), kteří ale pracovali samostatně a výsledky jejich práce vyšly tiskem až po Breithauptově smrti.

Prvním z nich byl Julius Albin Weisbach (*1833 †1901), po Breithauptovi profesor mineralogie Báňské akademie ve Freibergu, který $\mathrm{k}$ okolnostem nálezu dodává: „V roce 1833 narazil lesní dělník Karl August Reissmann při orání u Ehrenzipfelu (= dnes část obce Breitenbrunn, stejně jako Rittersgrün) na balvan „starého železa", který opakovaně a bezvýsledně nabízel na prodej jak kovári ve vesnici, tak v sousedním hamru. O mnoho let později slyšel o balvanu pan Kröner, tehdy šichtmistr na železné huti Siegelhof u Rittersbergu, prohlédnul si jej a podle zrn špinavě zeleného, olivínu podobného minerálu, zarostlých v uraženém kousku usoudil, že je to železo meteoritického pưvodu. Ale až teprve po letech, a sice $v$ roce 1861, nález železa a své poznatky sdělil báňskému radovi profesoru Breithauptovi. Ten cestoval okamžitě na místo, balvan našel v bytě lesního dělníka, presvědčil se o oprávněnosti Krönerových údajů a získal jej koupí pro mineralogickou sbírku Báňské akademie ve Freibergu". Mineralogické složení rittersgrünského meteoritu popisuje takto: „Výzkum ukázal, že celý meteorit při středni specifické váze 4.29 je ve svém objemu složen z asi 3/10 železa a 7/10 nekovové hnědé masy, která sestává přvážně z bronzitu podobnému hyperstenu, ve kterém je vtroušen bohatě pyrrhotin a sporadicky schreibersit. Z těchto složek byly pomocí zředěné kyseliny chlorovodíkové rozpuštěny železo a pyrrhotin, zatím co schreibersit, bronzit a ještě nějaká bilá substance zůstaly nerozpuštěné. Ta bílá se ukázala být složená pouze z kyseliny křemičité, identické s asmanitem, minerálem objeveným a popsaným Maskelynem roku 1871 v meteoritu z Breitenbachu v severních Čechách. Hnědý a nazelenalý bronzit $v$ nepodařených krystalových zrnech považovali sám Breithaupt (1861) a Rose (1864) za olivín, ale jeho chování pred dmuchavkou a reakce s kyselinou jsou odlišné. Šlo v této době o největší evropský železný meteorit po loketském „zakletém purkrabi““, z něhož ovšem ve vídeňském dvorním muzeu zbyla pětina" (Weisbach 1876). Součástí jeho publikace je vyobrazení naleštěné řezné plochy tohoto meteoritu (obr. 11).

Weisbach také vyslovil při pozorování průběhu Widmanstättenových obrazců na plochách nařezaného železa domněnku, že celý meteorit odpovídá jednomu individuu - jednomu krystalu železa, což ovšem naznačil již Breithaupt (1862b) a Buchner (1863).

Nejdůkladnější průzkum meteoritu Rittersgrün, včetně chemických analýz, provedl a v roce 1878 publikoval další profesor Báňské akademie ve Freibergu Clemens Winkler ( ${ }^{*} 1838$ - †1905), známý také svým objevem prvku germania (1886) v nerostu argyroditu (Anonym 1905). Winkler meteorit analyzoval jako celek a poté zvlášt' jeho kovové (niklové železo a schreibersit) a nekovové součásti (troilit, tridymit/,asmanit“, bronzit a vzácný chromit), které jsou $v$ celé hmotnosti meteoritu zastoupeny $\checkmark$ poměru 38.16 („kovové“) : 60.62 (nekovové). $V$ mnohém se zde Winkler odvolává na analýzy, které provedl Story-Maskelyne $(1869,1871)$ u meteoritu Breitenbach/ Potůčky (např. identifikace bronzitu-enstatitu a tridymitu „asmanitu“) a které byly platné i pro prakticky totožný meteorit Rittersgrün. Winkler se pokoušel analyzovat také plyny v meteoritu a věnoval se i složení dvojí povrchové vrstvy meteoritu, označované jako ožehnutá kưra (Brandrinde) či natavená kůra (Schmelzkruste) neboli glazura
(Glasur), nejednoznačného původu a geneze (Winkler 1878) (obr. 12).

Jak se vyjádřil již A. Weisbach, šlo v této době o největší evropský železný meteorit po loketském „zakletém purkrabím“. Z dalších evropských želez se Rittersgrünu vyrovnalo Lenarto (Lenártov u Bardejova), nalezeno 1814, původní váha 108 kg, dnes v Budapešti (cca 75 kg) a Magura (též Árva, Slanica), kde se z cca 1.5 t do roku 1844 porůznu nasbíraného meteoritického železa podařilo zachránit jen cca 100 kg (Haidinger 1844; Weiss 1845).

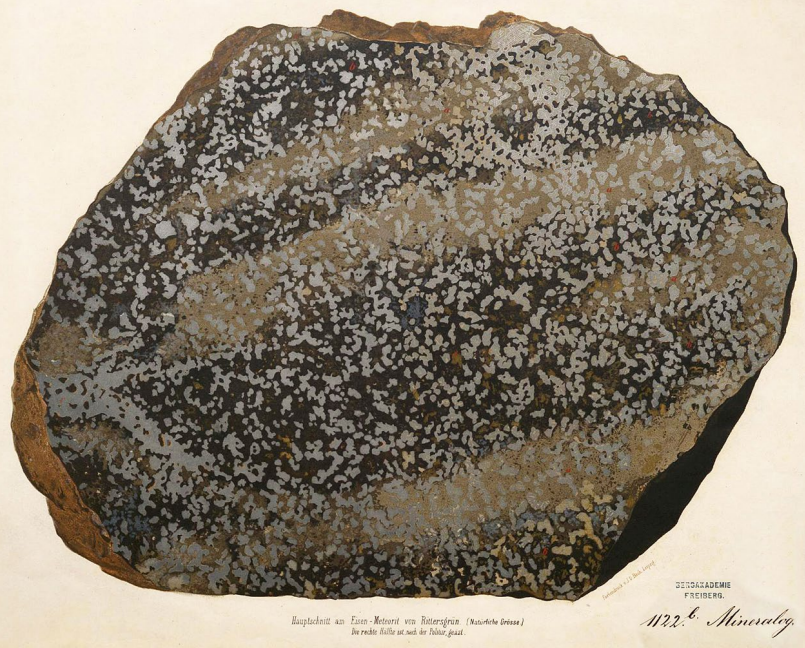

Obr. 11 Vyobrazení naleštěné plochy meteoritu Steinbach z Rittersgrünu z publikace J. A. Weisbacha z roku 1876

NOVA ACTA

der Ksl. Leop.-Carol.-Deutschen Akadenie der Yaturforscher Band XL, Nr. s.

Die

\section{Untersuchung des Eisenmeteorits}

ron

\section{Rittersgrün}
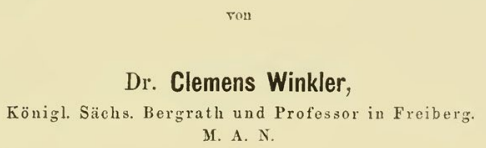

M. A. N.

Eingeyangen bei der Akodemie den $2 j$. August 1878 .

Drack von E. Blochimann \& Solua in Drosde

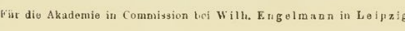

Obr. 12 Titulní strana publikace C. Winklera o meteoritu Steinbach z Rittersgrünu z roku 1878. 
Ehrenzipfel u Rittersgrünu, kde se meteorit při orání $\checkmark$ roce 1833 našel, se nalézal bezprostředně na české hranici ještě $v$ Sasku, oddělený poměrně frekventovanou silnicí od tzv. Patschrei v Čechách (= český hostinec Ludmilly Patsch - Gasthaus Zu Patscherei), v sousedství samoty Českého Mlýna (Böhmische Mühle), kde byl také hostinec. Oba tyto hostince byly strženy v 50. letech 20 . století, stejně jako většina dalších domů. Dodnes tu však několik původních domů stojí, a kromě pozůstatků dřívější zástavby, většinou $v$ podobě skromných zbytků zdiva $v$ lese, se nově objevily i rekreační novostavby. Na německé straně to ale kontinuálně žije dál, takže na kraji obce Ehrenzipfel směrem od Rittersgrünu najdeme parkoviště, odkud sv. směrem po červenomodré značce dojdeme asi po $500 \mathrm{~m}$ k informační tabuli „Dr Rittersgrüner Hommelsta" (= Himmelstein - Kámen z nebe) s vyznačením místa nálezu meteoritu.

Lokalizace nálezu je též vyznačena červenou hvězdičkou těsně na východním okraji mapy pod číslem 680 u Ehrenzipfelu na Geologické mapě Království saského, a sice v jejím druhém, J. Gäbertem revidovaném provedení z let 1899 a 1900. Ve vysvětlivkách k této mapě se udává, že naleziště meteoritu leží na levém svahu nad potokem a říčkou Pöhlwasser (Schalch, Gäbert 1900, 1901).

\section{Breitenbach - Potůčky}

Čtvrtý fragment meteoritu Steinbach byl nalezen v květnu roku 1861 u Potůčků (do roku 1948 Breitenbach) u Horní Blatné (Platten), pobliž hranice se Saskem. Byl nalezen „etwa eine Elle tief in der Dammerde” (,asi jeden loket hluboko $v$ ornici“) a jeho původní váha byla $10.5 \mathrm{~kg}$ (Buchner 1863). Podle toho byl nález učiněn někde na poli, tedy tam, kde se oralo a počítáme-li loket $60-70 \mathrm{~cm}$, pak by ovšem šlo o neuvěřitelně hlubokou orbu. Naznačuje to spíše lokalizaci do prostoru vlhké louky anebo místa těžby rašeliny, které jsou jasně vymezeny na císařském otisku

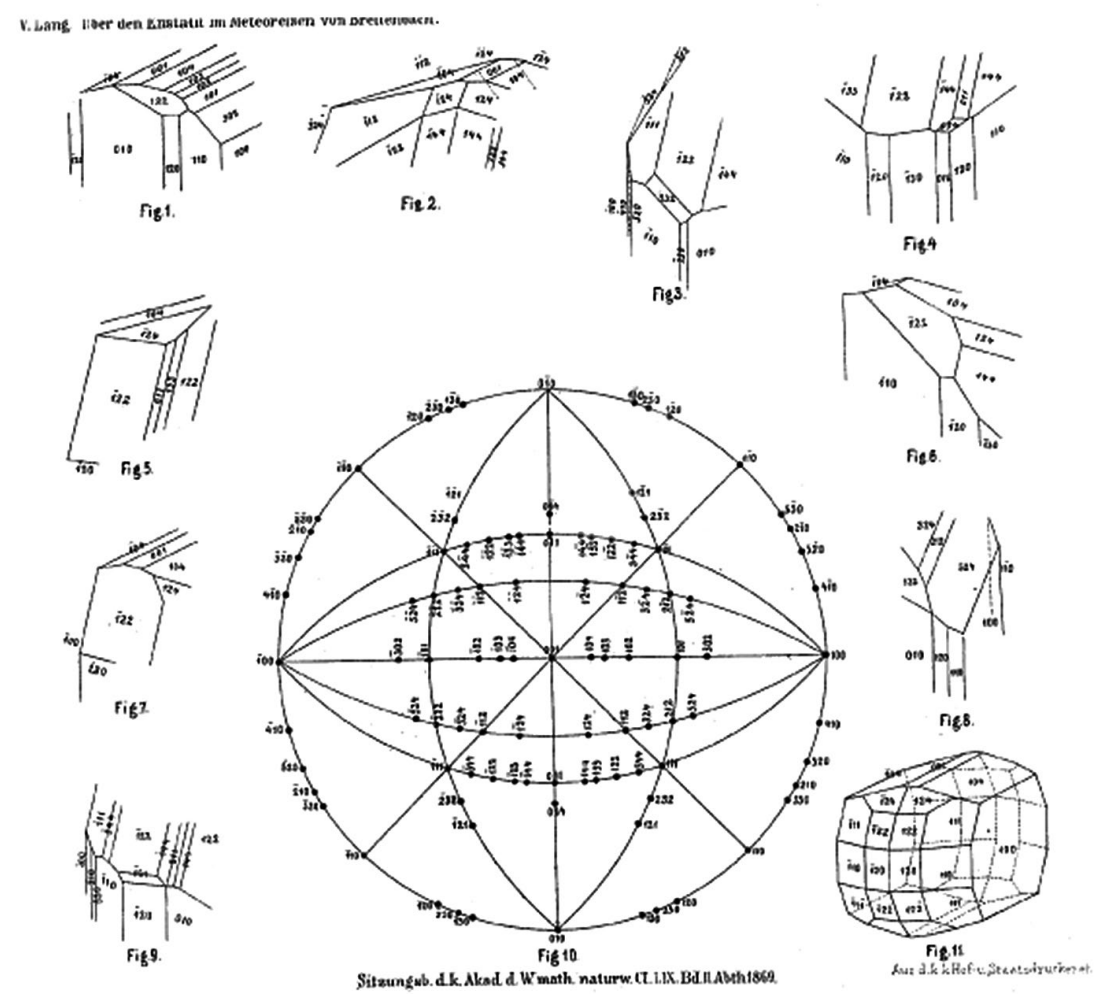

Obr. 13 Vyobrazení krystalů enstatitu z meteoritu Steinbach z Breitenbachu podle Langa (1869). mapového operátu stabilního katastru. Na zasedání Německé geologické společnosti v Berlíně 4. 5. 1864 předložil její předseda Gustav Rose jako nový zisk mineralogického muzea dva meteority: železo z Werchne Udinsk a druhý meteorit, který podle G. Roseho našel u Breitenbachu v Čechách pan Osius z Freibergu (in Freiberg). „Jeho největši část šla do Britského muzea v Londýně, Berlín obdržel jen malý kousek. Meteorit je směsí meteoritického železa s olivínem a některými jinými minerály, které ještě musí bý určeny. Bližší o okolnostech nálezu a vlastnostech železa sdělí objevitel (= Osius) ve zvláštním spisu“. Což Osius zřejmě z nějakých důvodů neučinil, alespoň jeho jméno nikde nenacházíme. Píše se ale poprvé, že ho u Potůčků našel, podruhé, že je jeho „objevitel“ nikoliv nálezce a to „ve Freibergu“ znamená, že tam sice pobýval, ale nemusel odsud pocházet a dostal nějaký tip a zajel se do Potůčků - asi ke skutečnému nálezci - podívat. Byl také potenciálně schopen vyprodukovat „zvláštní spis“ a také meteorit promptně prodat na nejvhodnější solventní adresu - Britské muzeum. Jméno Adolph Osius nacházíme $v$ roce 1861 mezi studenty Báňské akademie ve Freibergu (pocházel z Hanau) a v roce 1866 jako majitele lomu na serpentin v Limbachu (Anonym 1866), což může souviset i s jeho náhlým zbohatnutím.

$\checkmark$ roce 1863 byl již hlavní kus v Londýně a zde se ho ujal Mervyn Herbert Nevil Story-Maskelyne (profesor na Oxfordu a kurátor mineralogické sbírky Britského muzea, *1823 - †1911), který ho podrobil vskutku důkladnému zkoumání, jež se protáhlo na několik let, a na toto téma zveřejnil zásadní práce. Podle něj patří mezi vzácné železo-kamenné meteority, pro něž autor již nějaký rok razí termín siderolity. Nalezen byl roku 1861 v Breitenbachu v Čechách, poblíž míst, kde byly nalezeny prakticky totožné meteority Rittersgrün a Steinbach. Je to houbovitá kovová masa, podobná siderolitu z Rittersgrünu $v$ Sasku. Dutiny $v$ železe jsou naplněny směsí krystalických minerálů. První je světle zelený, jeho prizmatické krystaly připomínající olivín měřil jeho kolega $v$ Britském muzeu, Dr. Viktor von Lang (obr. 13) a chemicky jde o $\left(\mathrm{Mg}_{4 /}\right.$ $\left.{ }_{5} \mathrm{Fe}_{15}\right) \mathrm{SiO}_{3}$, což príibližně odpovídá enstatitu, ale až dokončené optické zkoumání tohoto minerálu rozhodne, zda jde skutečně o enstatit. Nejvýše zajímavý je druhý minerál. Je to oxid křemičitý, krystalizovaný v podobě a $v$ systému, odlišném od hexagonálního křemene a tvořícího asi třetinu smíšené krystalické masy. Jeho fyzikální a chemické zkoumání vedlo autora k závěru, že může jít o minerál, kterému dal von Rath jméno tridymit (Story-Maskelyne 1869).

Podrobněji pokračuje Story-Maskelyne $v$ další práci, ve které popisuje metodu, kterou sám vyvinul $\mathrm{k}$ mikrochemickému analyzování silikátů $v$ meteoritech, a kterou uplatnil i u meteoritu Breitenbach (Story-Maskelyne 1870).

Svou třetí práci věnoval StoryMaskelyne již převážně meteoritu Breitenbach/Potůčky. Po rozříznutí pozoroval na řezné ploše nepravidelné skvrny železa, meziprostory jsou vyplněny částečně „meteoritic- 
kým pyritem" (troilitem) v podobě malých tmavohnědých skvrn, zbytek tvoří zelenavá a šedohnědá krystalická masa. Z ní se mu podařilo vyseparovat a identifikovat: 1 . krystalická, jasně zelená či zelenožlutá zrna (železnatý enstatit čili bronzit); 2 . rezavě hnědá až téměř černá, někdy skoro bezbarvá zrna, vzácně s krystalovými plochami (dle autora odpovídá, ovšem až na krystalizaci v jiné soustavě, Rathovu tridymitu čili není s ním identický); 3. zrna chromitu. Zvláštní pozornost věnoval 2. složce, oxidu křemičitému (silica), tedy chemicky křemeni, který má ale v meteoritu Breitenbach nižší specifickou hmotnost a krystaly jsou ortorombické (kosočtverečné), na rozdíl od Rathova monoklinického (jednoklonného) tridymitu. Proto jej považuje za dosud neznámý minerál a dává mu jméno asmanit (obr. 14). Název vytvořil podle podoby krystalů nebot' „A'sman, A-Sman“ - korespondující s řeckým ákmon - je prý sanskrtský název pro „hromový klín“ (angl. thunderbolt) boha Indry (Story-Maskelyne 1871; Quenstedt 1872; Anonym 1873; Doelter 1914). Další minerální složky: troilit, něco málo schreibersitu a chromitu a konečně niklové železo tvořící svého druhu kostru, držící vše pohromadě (Story-Maskelyne 1871). Podrobně se Story-Maskelyne věnoval $v$ této práci bronzitu (Langovu enstatitu 1869), kde dokazuje, že je totožný s pozemským enstatitem, který jako nový minerál v roce 1855 popsal (před tím byl považován za skapolit či tremolit) Gustav A. Kenngott ze Žd'árské hory („revír Žd'ár“) u Rudy nad Moravou (Kenngott 1855). Při tom Story-Maskelyne možná netušil, že již v roce 1846 popsal Charles U. Shepard silikát hořčíku z meteoritu (enstatitického achondritu aubritu) od Bishopville v Jižní Karolině (pád 23. 3. 1843) pod jménem chladnit. Byl ale pro údajně zjištěný obsah vápníku považován za jakousi odrůdu wollastonitu, v níž je část Ca nahrazena Mg. S tím, že jde o jeho enstatit, si Kenngott $v$ roce 1862 reklamoval svoji prioritu, takže G. Rose chladnit roku 1864 prejmenoval na shepardit, později ovšem nikdy nepoužívané jméno. Staré analytiky mohlo mýlit, že tyto meteoritické enstatity obsahovaly určité množství oxidu železnatého, nemluvě o tom, že přesnost těchto analýz nebyla velká, protože potřebné, poměrně velké vzorky, musely být z celého objemu vyseparovány, takže materiál pro analýzu nemohl být úplně čistý (Doelter 1914). Nicméně bez ohledu na prioritu, byl enstatit od 70 . let 19. století již častěji konstatovanou složkou dalších meteoritů (Burke 1986). Zmíněný von Lang zkoumal od roku 1863 enstatit (bronzit) z meteoritu Breitenbach pouze opticky (krystalograficky), což měl ztížené tím, že z krystalické hmoty se daly vyseparovat jen fragmenty větších krystalů, které měly často navíc „falešné“ plochy, vzniklé kontaktem s přiléhajícími krystaly. Nicméně konstatoval, že enstatit je rombický. Hodnoty získané měřením ploch a jejich poměr k optickým osám zobrazil ve sférické projekci a použil je i pro znázornění podoby ideálního krystalu enstatitu (obr. 13) (Lang 1869).

Další zajímavou složkou meteoritu Steinbach je oxid křemičitý. O prítomnosti „křemene“ jsou zmínky již od počátků popisu těchto meteoritů. Zda však nedocházelo k záměně křemene se silikáty a podobně, dnes již nerozluštíme (Stieglitz 1769; Anonym 1776; Partsch 1843).

Důležité je, že Story-Maskelyne při zkoumání meteoritu Breitenbach konstatuje, že je svým složením totožný $s$ meteority Steinbach a Rittersgrün. Objevitel tridymitu G. v. Rath brzy na to „asmanit“ z meteoritu Breitenbach zkoumal také a nepochybuje, že jde po křemeni a jeho tridymitu o třetí modifikaci $\mathrm{SiO}_{2}$. Asmanit tvoří kuličkovité krystaly $0.5-3 \mathrm{~mm}$ velké jen vzácně s vyvinutými krysta- lovými plochami. Dá se těžko v silikátové hmotě meteoritu rozeznat, až po pojednání se zředěnou $\mathrm{HCl}$ se objeví světlešedá zrna bronzitu a bezbarvá zrna asmanitu (Rath 1873). Časem se však ukázalo, že tento nový minerál asmanit, popsaný v materiálu z území Čech, je vlastně paramorfózou tridymitu po beta-tridymitu, tedy tridymitem, a objev skutečné třetí modifikace $\mathrm{SiO}_{2}$ - cristobalitu - zůstal vyhrazen opět Gustavu von Rathovi, který ho popsal ze stejné lokality jako tridymit z Cerro St. Cristobal v Mexiku. Nicméně tridymit jako složka meteoritů zůstal na dlouhá léta omezen pouze na meteority Breitenbach a Rittersgrün.

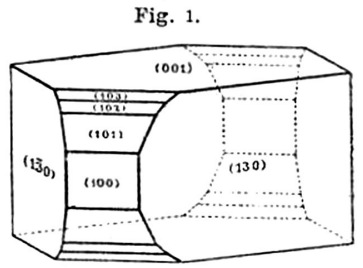

Obr. 14 Krystal tridymitu (asmanitu) z meteoritu Steinbach z Rittersgrünu (Cohen 1894).

\section{Bornův meteorit - pochybný železokámen IVA-an}

Určitou záhadu mezi těmito starými meteority představuje meteorit z Čech, který vlastnil Ignác rytír Born ( ${ }^{*} 1742$ - †1791), o němž jsme se již zmínili. V katalogu své sbírky jej popisuje takto (Born 1772): Železo magnetem pritahované, $v$ lesklých zrnkách $v$ zelenavé matrici, zelenavé železo (Ferrum virens) dle Linnéa, jehož fragmenty, od jednoho do dvaceti pfundů těžké (0.5 - 10 kg), obalené černou struskovitou kưrou, u Plané u Tábora v kraji Bechyňském v Čechách, se hromadně objevily. Lehkověrní lidé se domnívají, že 3. července 1751 během bouřky spadly z nebe.

Bornovo datum přesně odpovídá pozorovanému pádu meteoritických kamenů u Tábora (mezi obcí Planá n. Lužnicí a Strkov, též obec Kravín), zaznamenaném v tisku i doklady ve sbírkách. Bornův popis však táborským meteoritickým kamenům (šlo o chondrity) odpovídá už méně, spíše jde železokámen. Bornovu sbírku zakoupil v roce 1775 lord Charles Greville v Londýně, který sporný „Stone from Bohemia/Kámen z Čech" (nebo jeho část) zapůjčil ke zkoumání Edvardu Charlesi Howardovi (objeviteli niklu v meteoritických železech, *1774 - † 1816) a Jacquesi Louisi Comte de Bournonovi (*1751 - †1825). Bournon na „Stone from Bohemia“ zjistil: jeho zrno je drobnější než u ostatních želez. $V$ celé hmotě je možno pozorovat šedé globule (kuličky) a částečky nepravidelného tvaru a stejné částice kovového železa. Jakási zemitá (nekovová) substance tmelí celou masu. Svým materiálním složením se liší od ostatních meteoritů tím že: 1. obsahuje lupou viditelné částečky pyritu (?). 2. obsahuje mnohem více železa $v$ kovové podobě, které tvoří asi $25 / 100$ celého objemu. 3 . Protože asi leželo dlouho na zemském povrchu (mělo ale černou krustu), částečky železa $v$ něm jsou oxidované, což produkuje velké množství žlutohnědých bodů (silikáty?) v celé vnitřní substanci. Ty působí současně jako cement, který celou hmotu udržuje kompaktní za součinnosti kovového železa, které je obsaženo ve velkém množství. 4 . Specifická váha meteoritu je 4.281. Chemicky ho analyzoval Howard, který dostal k dispozici jen malé množství 55 gránů (tj. asi $3.5 \mathrm{~g}$ ) zemité = nekovové části kamene a zjistil, že 
obsahuje 25 gránů (asi $1.6 \mathrm{~g}$ ) oxidu křemíku (silica), 9.5 gránů oxidu hořčíku (magnesia), 23.5 gránů oxidu železa (oxide of iron) a 1.5 gránů oxidu niklu (oxide of nickel). Což Howardovi príliš nevyšlo, snaží se to vysvětlit a zároveň se diví, proč se tolik liší od výsledků ostatních analytiků jiných „kamenů z nebe“. Očekával by, že výsledky budou spíš shodné. Dále pak vyslovuje domněnku, něčím konkrétním asi podloženou, že vzorek železa z Čech byl věnován Ignáci Bornovi Báňskou akademií ve Freibergu (dokonce s lokalitou Tábor 1751?) a později přešel s celou Bornovou sbírkou do rukou lorda Grevilla. Bournon srovnává Bornův meteorit s pallasitem a konstatuje, že u Pallasova železa, jakož i u českého, jde o směs železa a niklu. Ryzí železo z Čech je kompaktní masa, podobná kompaktnějším partiím sibiřského železa. Tak jako ono, obsahuje množství kulovitých těles či nodulí, které ale nemaji tak velkolepé proporce jako u sibiřského železa. Jsou vedle toho perfektně opakni a velice pripomínaji nejkompaktnějši globule. Snad tím měl na mysli uzavřeniny silikátů v meziprostorách železa, které se jevily jako kulovité a proto, že neměl $\mathrm{k}$ dispozici žádný dostatečně tenký řez, mohly mu všechny připadat opakní (Howard 1802; Bournon in Howard 1802). Howardem zjištěná specifická hmotnost 4.281 (čisté železo $7.3-7.8$ ) značně převyšovala onu meteoritických kamenů (kolem 3.5). Naproti tomu Bornova „nazelenalá matrice" táborských meteoritických kamenů, které jsou na lomu spíš šedobílé, nepřipadá v úvahu. Jde tedy evidentně o železokámen, který se nějak před rokem 1772 dostal do Bornovy sbírky s chybným popisem „Tábor 1753“ a patří pravděpodobně také k meteoritům Steinbach. Bornova, respektive Grevillova sbírka je dnes v Britském muzeu v Londýně a sporné železo by se pravděpodobně dalo identifikovat. Nejasné je to se vzorkem, který měli k dispozici Howard a Bournon; pokud se nespotřeboval pro analýzu, někde zůstal (Burke 1986). Ignác Born měl tohoto materiálu „Tabor 1851“ asi víc, protože od něj pravděpodobně pocházel obdobný vzorek, který se ze sbírky M. H. Klaprotha (Klaproth 1803) a přes berlínské muzeum dostal do Vídně (Partsch 1843).

První česky psaná práce o meteoritech je od Maximiliána Millauera $\left({ }^{*} 1784\right.$ - †1840), profesora teologické fakulty pražské univerzity a jednatele Národního muzea, ve které najdeme i úvahu o Bornově meteoritu, v tehdejším českém pravopisu (jak jsme viděli již u Presla) poněkud nesrozumitelnou: „O onom samorostlém powětrném železu z Čech od nepowědomého času, které z Bornské sbírky do oné Charla Grevilla v Londýně, z této wssak do taměgssjho Museum britannicum přisslo, a odewssech giných powědomých powětroňu podstatně se rozeznáwá, proto jsem tuto zmínku učiniti nechtěl, že to bud' ono powětrné Aes od roku 1618, neb také zcela cyzý býti může. Sám rytjř Born gedná (w swém Lithophylacium Bornianum, w Praze 1772 djlu I. str. 125) gen o Taborytu od r. 1753 skrze pana hornjho Radu z Schindlerů obdrženém, tedy ge bud' ani za powětrné neuznal, aneb s těmito posledními powětrnými plodinami smíchal, kdežto částky Taborytu geho u Pana Doktora Chladného str. 247 - ony wssak od tohoto rozdjlné též w sbjrce geho nalezeného samorostlého (wětwowatého olegkowého? (olejek, olegek = Preslův olivín) powětrného železa u Pana Doktora Chladného str. 324 oba - dle wyssetrowánj od Pánů Howarda a Bournona předsewzatého - uwedeny gsau“ (Millauer 1825, 47-48).

Analýza tohoto meteoritu spadala do doby, kdy zdaleka ne všichni vědci byli úplně přesvědčení o vesmírném původu „kamenů z nebe“ (zdá se, že včetně Howarda), k dispozici bylo málo meteoritů pro srovnání a očekávalo se, že budou svým složením všechny stejné, nemluvě o tom, že analytické metody byly $v$ plenkách. Přesto Howard a Bournon našli ve vzorku (měla to být ovšem jen vyseparovaná nekovová část) železo a nikl, hořčík (enstatit?) a křemík (silikáty?, tridymit?).

Dodejme na tomto místě, že výše uvedený Howardův a Bournonův výzkum byl prvním kvalitnějším chemickým zkoumáním meteoritů vůbec, včetně onoho z Čech (Matzner 1928).

\section{Mineralogie meteoritů}

Shrneme-li tedy nastíněnou, poněkud komplikovanou historii nálezů a výzkumu meteoritů Steinbach, je možné konstatovat, že v Krušných horách $v$ hraniční oblasti s Německem bylo přibližně v letech 1724 až 1861 nalezeno několik identických kameno-železných meteoritů o celkové hmotnosti kolem sto kilogramů (největší exemplář 87 kg u Rittersgrünu).

Všechny patří podle klasifikace meteoritů mezi velmi vzácné anomální meteority skupiny IVA-an, jichž je na světě znám jen malý počet. Spolu s meteoritem Steinbach je $v$ této skupině dalších pět meteoritů, $z$ nichž jen dva obsahují významný podíl silikátů (včetně tridymitu). Kromě Steinbachu to je již zmiňovaný Sao Joao Nepomuceno. Jsou charakterizovány obsahem niklového železa, které uzavírá zrnitý agregát pyroxenu a menší množství tridymitu, s přibližně stejně zastoupenou nikl-železnou a silikátovou složkou, akcesorickými minerály, kterými jsou schreibersit $v$ niklovém železe, chromit a troilit. Niklové železo tvoří Widmanstättenovy obrazce. Ortopyroxen obsahuje kolem 20 mol. \% ferosilitové komponenty a podle dřivější klasifikace se nacházel na hranici mezi bronzitem a hyperstenem (Mason 1962). Podle současné klasifikace pyroxenů (Morimoto et al. 1988) jde o železem bohatý enstatit.

Meteority Steinbach $v$ minulosti zkoumali a analyzovali Story-Maskelyne (1871), Winkler (1878) a Heide (1923), jejichž výsledky prokázaly identitu jednotlivých nálezů. Nověji byl elektronovou mikroanalýzou analyzován fragment meteoritu ze Steinbachu v Přírodovědném muzeu ve Vídni (Dörfler et al. 1965). Jejich výzkum potvrdil již dř́ve známé mineralogické složení meteoritu. Autoři charakterizovali kovovou složku tvořenou kamacitem a taenitem v podobě Widmanstättenových obrazců a jejich jemnozrnnou směsí plessitem. Z nekovových fází uvádějí jako hlavní bronzit, tridymit a troilit, v malém nožství chromit a oxidy Fe. Složení nekovových fází, které byly stanoveny kvantitativní analýzou, se jen mírně odlišovalo od zjištění předchozích autorů. Zajímavým rysem je relativně vysoký obsah manganu v bronzitu $(0.31 \%)$ a v chromitu $(1.36 \%)$ a také obsah chrómu v troilitu $(0.61 \%)$.

Dollase (1967) studoval strukturu tridymitu, který tvoří v meteoritu častá, až $5 \mathrm{~mm}$ velká zrna. Zjistil, že jde o jeho vyšší rombickou modifikaci s prostorovou grupou $C$ $222_{1}$, jehož struktura je oproti ideálnímu stavu poněkud deformovaná díky tepelným procesům, kterým byl tridymit v meteoritu vystaven.

Dalšími autory, kteří se zabývali mineralogickým složením steinbašského meteoritu, byli Ried et al. (1974). Na základě rtg. analýzy zjistili, že vedle ortorombického bronzitu (enstatitu) je zastoupen v malém množství i monoklinický pyroxen (klinoenstatit), které jsou z chemického hlediska velmi podobné. Oba pyroxeny podle těchto autorů vznikly z původního protobronzitu. Ortopyroxen tvoři až $5 \mathrm{~mm}$ velká, alotriomorfně omezená zrna, na jejichž trhlinách byla zjištěna jeho monoklinická forma. 
V rámci analýz tridymitu zjistili Ried et al. (1974), že vedle $\mathrm{SiO}_{2}$ obsahuje malou príměs $\mathrm{Al}_{2} \mathrm{O}_{3}(0.25 \%)$. Ulff-Møller et al. (1995) uvádějí, že klinopyroxen tvoří lamely v jádrech některých polykrystalických zrn ortopyroxenu a jen občasně se vyskytuje na trhlinách.

Ruzicka a Hutson (2006) uvádějí, že klinoenstatit obsahuje oproti enstatitu časté drobné $(<10 \mu \mathrm{m})$ inkluze troilitu a je méně kompaktní (obsahuje časté trhliny). $\mathrm{Na}$ základě chemických analýz vyčlenili dva subtypy ortorombického enstatitu (typ 1 a 2), které mají sice velmi podobné chemické složení, ale subtyp 2 má větší variabilitu v obsazích $\mathrm{Al}, \mathrm{Ca}$ a $\mathrm{Cr}$. Ve své práci též uvádějí chemické složení tridymitu a chromitu. Stanovili též modální složení meteoritu Steinbach na třech jednotlivých řezných plochách a porovnávají je s údaji Ulff-Møllera et al. (1995) a Scotta et al. (1996). Zastoupení jednotlivých složek je následující (Ruzicka, Hutson 2006/Ulff-Møller et al. 1995/ Scott et al. 1996): klinopyroxen (4.3/4.5/1.6), ortopyroxen (41.2/37.3/38.0), tridymit (24.7/20.2/20.8), chromit (0.4//0), troilit (7.2/5.7/6.6), Fe-Ni kov (23.4/32.4/32.2).

$\checkmark$ poslední době se meteorit Steinbach stal též předmětem řady dalších vědeckých studií, které se snažily objasnit jeho původ a vznik (vedle již zmiňovaného Ruzicky, Hutsona 2006 jde např. o publikace Brysona et al. 2017; Connellyho et al. 2019; Ruzicky 2014; Yanga et al. 2008; Wassona et al. 2006). Connelly et al. (2019) vypočetli pomocí U-Pb chronometrie stáří meteoritu Steinbach na 4.56547 ( \pm 0.010$) \mathrm{Ga}$.

\section{Metodika výzkumu}

$\checkmark$ rámci provedeného výzkumu byl na lokalitě Glücksburg a v jejím okolí proveden detektorový průzkum s detektory Minelab CTX 3030, EQUINOX 800 a Teknetics EuroTek PRO7. Nálezy byly zaměřovány submetrovou GNSS Geo7x, prípadně GPS Garmin Oregon 400.

Chemické složení jednotlivých minerálních fází meteoritu bylo kvantitativně studováno pomocí elektronového mikroanalyzátoru Cameca SX100 (Národní muzeum, Praha). Při bodových analýzách sulfidů, fosfidů a kovového železa bylo použito urychlovací napětí $25 \mathrm{kV}$, proud svazku 20 nA a průměr elektronového svazku $0.7 \mu \mathrm{m}$. Použité standardy a analytické čáry: Ag (AgLa), Au (AuMa), baryt $(\mathrm{BaL} \alpha), \mathrm{Bi}_{2} \mathrm{Se}_{3}(\mathrm{BiM} \beta)$, CdTe (CdL $\left.\alpha\right)$, Co (CoKa), $\mathrm{CuFeS}_{2}$ (CuKa, SKa), Cr (CrKa), FeS 2 (FeKa), fluorapa-

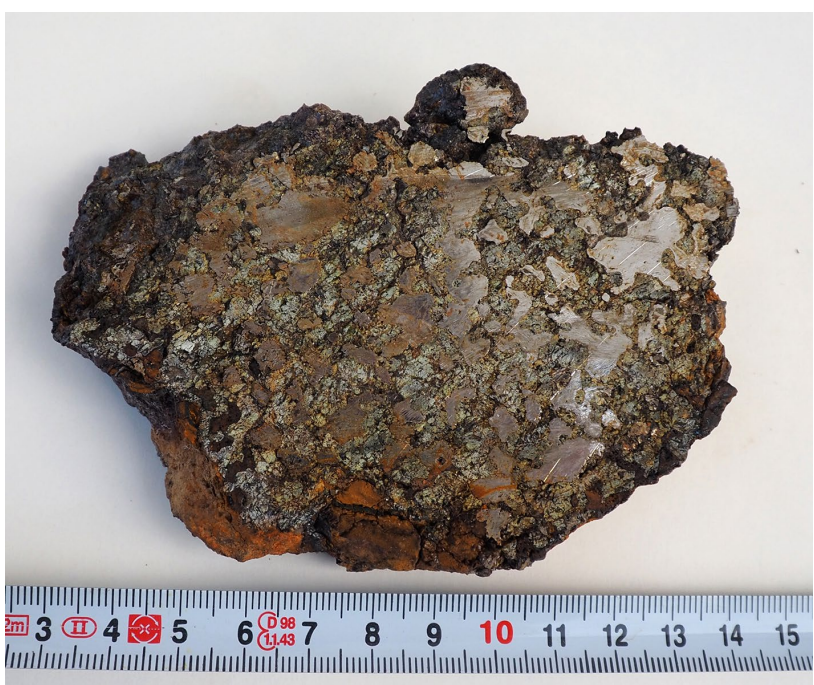

Obr. 15 Průřez fragmentem prvního meteoritu, rozměry $13 \times 8 \mathrm{~cm}$, foto P. Pauliš tit (PKa), GaAs (GaLa), Ge (GeLa), HgTe (HgLa), InAs $(\operatorname{lnL} \alpha), \mathrm{Mn}(\mathrm{MnK} \alpha), \mathrm{NaCl}(\mathrm{ClK} \alpha)$, NiAs (AsL $\beta), \mathrm{Ni}(\mathrm{NiK} \alpha)$, $\mathrm{PbS}(\mathrm{PbM} \alpha), \mathrm{PbSe}(\mathrm{SeL} \beta), \mathrm{PbTe}(\mathrm{TeL} \alpha)$, sanidin (KKa), $\mathrm{Sb}_{2} \mathrm{~S}_{3}(\mathrm{SbL} \alpha), \mathrm{Sn}(\mathrm{SnL} \alpha)$ a ZnS (ZnKa). Měřící časy na píku se pohybovaly mezi 10 a $30 \mathrm{~s}$, měřící časy pozadí trvaly polovinu času měření na píku. Načtená data byla přepočítána na hm. \% s použitím standardní PAP korekce (Pouchou, Pichoir 1985). Obsahy měřených prvků, které nejsou uvedeny $v$ níže uvedených tabulkách, byly ve všech př́padech pod mezí stanovitelnosti, jejíž hodnoty se obvykle pohybovaly mezi 0.03 a $0.07 \mathrm{hm}$. \%, u Ag, Au, $\mathrm{Se}, \mathrm{Pb}, \mathrm{Bi}$ mezi 0.1 a $0.2 \mathrm{hm}$. \% a u Hg kolem $0.8 \mathrm{hm}$. \%.

Kyslíkaté fáze byly měřeny při použití urychlovacího napětí $15 \mathrm{kV}$, proudu svazku $10 \mathrm{nA}$ a průměru svazku 2 $\mu \mathrm{m}$. Při analýze chromitu byly měřeny obsahy $\mathrm{Al}, \mathrm{Ca}, \mathrm{Cr}$, $\mathrm{Fe}, \mathrm{Mg}, \mathrm{Mn}, \mathrm{Ni}, \mathrm{P}, \mathrm{Si}, \mathrm{Ti}, \mathrm{V}, \mathrm{Zn}$ a Zr, při analýzách pyroxenů a tridymitu $\mathrm{Al}, \mathrm{Ba}, \mathrm{Ca}, \mathrm{Cl}, \mathrm{Cr}, \mathrm{Cu}, \mathrm{F}, \mathrm{Fe}, \mathrm{Mg}, \mathrm{Mn}, \mathrm{N}, \mathrm{Na}$, $\mathrm{Ni}, \mathrm{P}, \mathrm{S}, \mathrm{Si}, \mathrm{Sr}, \mathrm{Ti}, \mathrm{V}, \mathrm{Zn}$ a Zr a při analýzách fosfátu Al, As, $\mathrm{Ba}, \mathrm{Bi}, \mathrm{Ca}, \mathrm{Cl}, \mathrm{Co}, \mathrm{Cr}, \mathrm{F}, \mathrm{Fe}, \mathrm{Mg}, \mathrm{Mn}, \mathrm{N}, \mathrm{Na}, \mathrm{Ni}, \mathrm{P}, \mathrm{Pb}, \mathrm{S}$, $\mathrm{Si}, \mathrm{Sn}, \mathrm{Sr}, \mathrm{Ti}, \mathrm{V}, \mathrm{Y}$ a Zn. Použité standardy a analytické

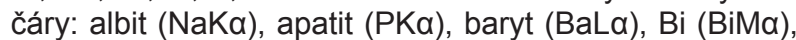
celestin (SKa, SrL $\beta$ ), Co (CoKa), $\mathrm{Cr}_{2} \mathrm{O}_{3}(\mathrm{CrK \alpha})$, diopsid $(\mathrm{MgK \alpha})$, halit $(\mathrm{ClK} \alpha)$, hematit (FeKa), chalkopyrit (CuKa), $\mathrm{LiF}(\mathrm{FK} \alpha), \mathrm{Ni}(\mathrm{NiK \alpha})$, rodonit (MnKa), sanidin (AlKa, KKa), $\mathrm{Sn}(\mathrm{SnL} \alpha), \mathrm{TiO}_{2}(\mathrm{TiK \alpha}), \mathrm{V}(\mathrm{VK \alpha})$, vanadinit $(\mathrm{PbM \alpha})$, wollastonit (CaKa), $\mathrm{YVO}_{4}(\mathrm{YL \alpha})$, zirkon (ZrLa), ZnO (ZnKa). Měříci časy na píku se pohybovaly mezi 10 a 30 s (u du-

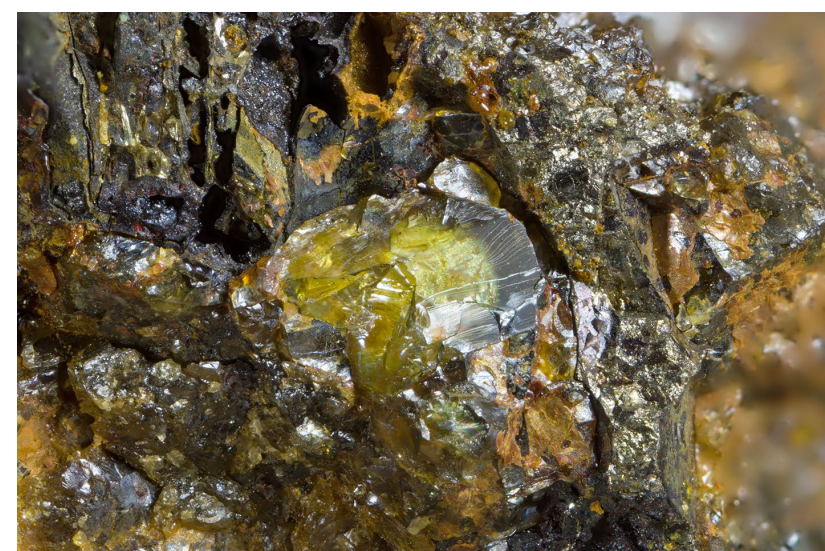

Obr. 16 Zrna enstatitu z meteoritu nalezeného na Glücksburgu, šírka záběru $5.7 \mathrm{~mm}$, foto $B$. Bureš.

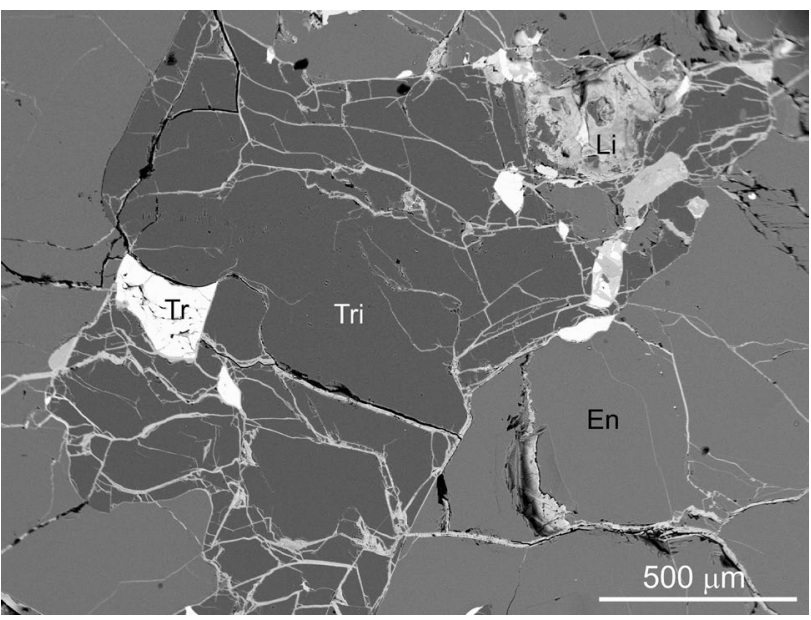

Obr. 17 Xenomorfně omezené zrno tridymitu (Tri) uzavřené $v$ enstatitu (En). Světle šedé agregáty a žilky jsou tvořeny limonitem (Li), bilá zrna troilitem (Tr). BSE foto Z. Dolníček. 
Tabulka 1 Chemické složení enstatitu z nově nalezeného meteoritu. Obsahy oxidů jsou $v \mathrm{hm}$. \%, hodnoty apfu jsou vyjádřeny na základ 3 atomů kyslíku.

\begin{tabular}{lrrrrrrr}
\hline An. č. & 1 & 2 & 3 & 4 & 5 & 6 & 7 \\
\hline $\mathrm{SiO}_{2}$ & 56.63 & 56.63 & 56.79 & 56.78 & 57.16 & 56.58 & 56.67 \\
$\mathrm{Al}_{2} \mathrm{O}_{3}$ & 0.22 & 0.33 & 0.30 & 0.22 & 0.29 & 0.11 & 0.04 \\
$\mathrm{Cr}_{2} \mathrm{O}_{3}$ & 0.34 & 0.57 & 0.53 & 0.43 & 0.48 & 0.36 & 042 \\
$\mathrm{FeO}$ & 10.50 & 10.59 & 10.56 & 10.12 & 10.27 & 10.49 & 10.18 \\
$\mathrm{MnO}$ & 0.48 & 0.55 & 0.57 & 0.51 & 0.49 & 0.58 & 0.62 \\
$\mathrm{MgO}$ & 31.35 & 30.97 & 30.87 & 31.47 & 31.18 & 31.44 & 31.66 \\
$\mathrm{CaO}$ & 0.22 & 0.42 & 0.45 & 0.25 & 0.38 & 0.20 & 0.23 \\
\hline $\mathrm{Celkem}^{2}$ & 99.74 & 100.06 & 100.07 & 99.78 & 100.25 & 99.76 & 99.82 \\
\hline $\mathrm{Si}^{4+}$ & 0.998 & 1.007 & 0.998 & 0.999 & 1.001 & 0.997 & 0.997 \\
$\mathrm{Al}^{3+}$ & 0.005 & 0.007 & 0.006 & 0.005 & 0.006 & 0.002 & 0.001 \\
$\mathrm{Cr}^{3+}$ & 0.005 & 0.008 & 0.007 & 0.006 & 0.007 & 0.005 & 0.006 \\
$\mathrm{Fe}^{2+}$ & 0.155 & 0.152 & 0.155 & 0.149 & 0.150 & 0.155 & 0.150 \\
$\mathrm{Mn}^{2+}$ & 0.007 & 0.008 & 0.008 & 0.008 & 0.007 & 0.009 & 0.009 \\
$\mathrm{Mg}^{2+}$ & 0.824 & 0.794 & 0.809 & 0.825 & 0.814 & 0.826 & 0.830 \\
$\mathrm{Ca}^{2+}$ & 0.004 & 0.008 & 0.008 & 0.005 & 0.007 & 0.004 & 0.004 \\
\hline $\mathrm{Suma} \mathrm{kat.}^{2+}$ & 1.998 & 1.984 & 1.991 & 1.997 & 1.992 & 1.998 & 1.997 \\
\hline & & & & & & &
\end{tabular}

Tabulka 2 Chemické složení tridymitu z nově nalezeného meteoritu (hm. \%), bdl - obsah pod mezí stanovitelnosti.

\begin{tabular}{lrrrrrr}
\hline An. č. & 1 & 2 & 3 & 4 & 5 & 6 \\
\hline $\mathrm{SiO}_{2}$ & 99.70 & 96.69 & 99.80 & 101.29 & 100.75 & 100.22 \\
$\mathrm{Al}_{2} \mathrm{O}_{3}$ & 0.21 & 0.26 & 0.22 & 0.24 & 0.21 & 0.10 \\
$\mathrm{FeO}$ & 0.05 & 0.09 & 0.05 & 0.40 & 0.12 & 0.16 \\
$\mathrm{Na}_{2} \mathrm{O}$ & 0.17 & 0.10 & 0.08 & 0.15 & 0.32 & bdl \\
\hline Celkem & 100.13 & 97.14 & 100.15 & 102.08 & 101.40 & 100.51 \\
\hline
\end{tabular}

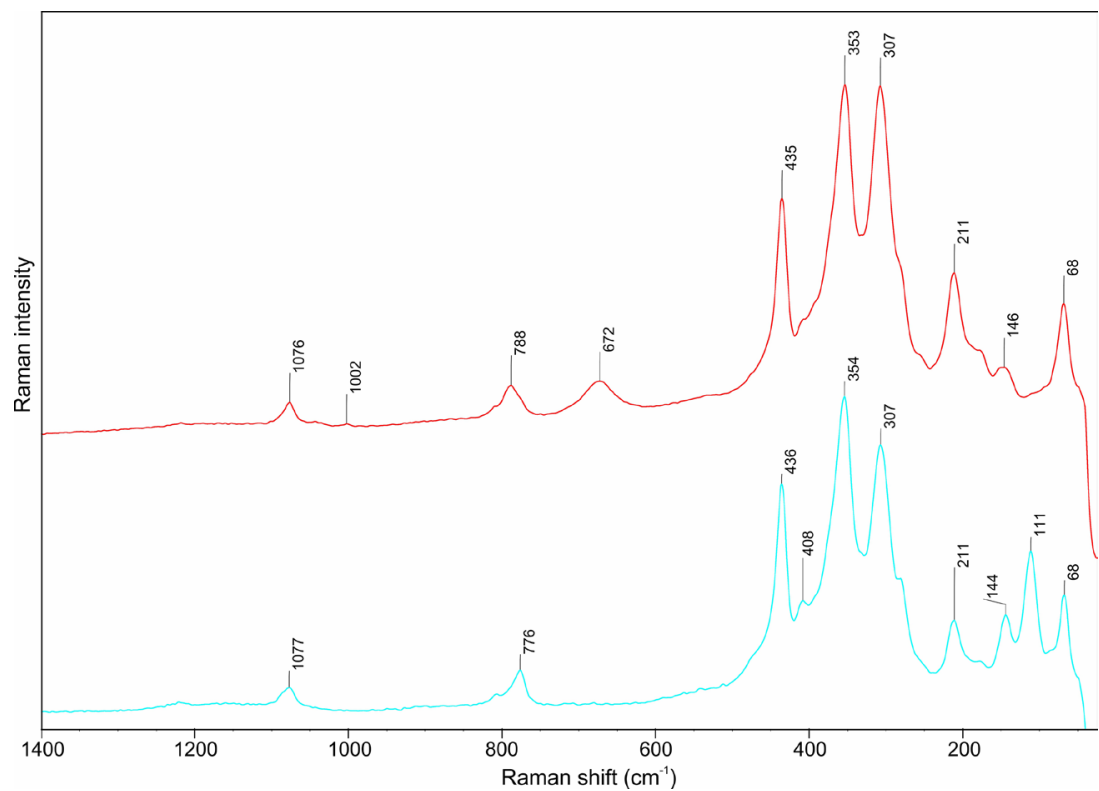

Obr. 18 Ramanova spektra tridymitu z meteoritu Steinbach z nového nálezu na Glücksburgu $\left(1400-45 \mathrm{~cm}^{-1}\right)$. síku 120 s), měřící časy pozadí trvaly polovinu času měření na píku. Načtená data byla přepočítána na hm. \% s použitím standardní PAP korekce (Pouchou, Pichoir 1985) a automatickým dopočtem stechiometrického množství kyslíku. Obsahy měřených prvků, které nejsou uvedeny v níže uvedených tabulkách, byly ve všech prípadech pod mezí stanovitelnosti, jejiž hodnoty se obvykle pohybovaly mezi 0.03 a 0.07 hm. \%, s výjimkou $\mathrm{Pb}, \mathrm{Bi}, \mathrm{Sr}, \mathrm{Ba}, \mathrm{Zn}, \mathrm{Mn}$ a $\mathrm{Cu}, \mathrm{u}$ nichž byly mezi 0.10 a $0.22 \mathrm{hm}$. \%.

Ramanova spektra byla pořizena za pomoci Ramanova disperzního spektrometru DXR (Thermo Scientific) s konfokálním mikroskopem Olympus (Národní muzeum). Spektra byla získána za použití červeného laseru $(633 \mathrm{~nm})$ o výkonu $8 \mathrm{~mW}$ $v$ měřícím rozsahu $45-3600 \mathrm{~cm}^{-1}$, za použití objektivu 50× a "bodové“ apertury o průměru $50 \mu \mathrm{m}$. Každé spektrum bylo načítáno 10 minut (expoziční čas 3 s, 200 skenů). U získaných spekter nebyly aplikovány žádné korekce na fluorescenci a byla zpracována v programu Omnic 9.

Monokrystalová difrakční data tridymitu byla získána pomocí rentgenového monokrystalového difraktometru Rigaku SuperNova vybaveného CCD detektorem Atlas S2 (Fyzikální ústav AV ČR, Praha), za použití intenzívního monochromatizovaného MoKa záření z mikrofokusní RTG lampy.

Nedestruktivní gamaspektrometrická radionuklidová analýza byla provedena na Katedře jaderné fyziky a biofyziky Univerzity Komenského $\checkmark$ Bratislavě pomocí vysoce citlivého HPGe detektoru o relativní účinnosti $70 \%$, který byl umístěný v nízkopozad'ovém těsnícím krytu o rozměrech $2 \times 1.5 \times 1.5 \mathrm{~m}$, který je tvořený železným, olověným, měděným a polyetylénovým těsněním s príměsí bóru (Povinec et al. 2015, 2020). Monte Carlo kalibrace byla provedena pomocí softwaru GEANT. Doba měření vzorku meteoritu o hmotnosti cca $40 \mathrm{~g}$ byla 533 hodin.

\section{Minerální složení nově naleze- ného meteoritu}

Mineralogický výzkum obou nově nalezených fragmentů meteoritů Steinbach byl proveden na naleštěných preparátech, které byly studovány na elektronové mikrosondě. Nekovové partie (cca 2/3 plochy nábrusů, obr. 15) jsou tvořeny enstatitem, jehož nepravidelná zeleně zbarvená zrna dosahují rozměrů 
1 - 5 mm (obr. 16). Většinou jsou matná, jen ojediněle dosahují skelného lesku. $V$ nábrusu jsou jednotlivá zrna enstatitu izometrická až mírně protažená, s xenomorfním omezením. V BSE obraze je studovaný minerál homogenní (obr. 17). Při studiu jeho chemického složení (tab. 1) byly vedle dominantních $\mathrm{MgO}$ a $\mathrm{SiO}_{2}$ zjištěny i zvýše-

Tabulka 3 Mřižkové parametry tridymitu z nově nalezeného meteoritu a jejich srovnání s publikovanými údaji pro monoklinický tridymit.

\begin{tabular}{crrrr}
\hline $\begin{array}{l}\text { vzorek, lokalita } \\
\text { reference }\end{array}$ & $\begin{array}{r}\text { meteorit Potůčky } \\
\text { tato práce }\end{array}$ & $\begin{array}{r}\text { meteorit Steinbach } \\
\text { Dolasse }(1967)\end{array}$ & $\begin{array}{r}\text { imp. kráter Chesapeake Bay } \\
\text { Jackson et al. (2011) }\end{array}$ & $\begin{array}{r}\text { syntetický } \\
\text { Nukui et al. (1978) }\end{array}$ \\
\hline$a[\AA]$ & $18.521(7)$ & 18.524 & 18.457 & 18.49 \\
$b[\AA]$ & $5.0027(16)$ & 5.003 & 4.994 & 4.991 \\
$c[\AA]$ & $23.821(10)$ & 23.810 & 23.817 & 25.83 \\
$\beta\left[{ }^{\circ}\right]$ & $105.79(4)$ & 105.82 & 105.87 & 117.75 \\
\hline
\end{tabular}

Tabulka 4 Chemické složení chromitu z nově nalezeného meteoritu. Obsahy oxidů jsou v hm. \%, hodnoty apfu jsou vyjádřeny na základ 4 atomů kyslíku, obsahy koncových členů v mol. \%.

\begin{tabular}{lrrrrrrr}
\hline An. č. & 1 & 2 & 3 & 4 & 5 & 6 & 7 \\
\hline $\mathrm{SiO}_{2}$ & 0.19 & 0.14 & 0.14 & 0.24 & 0.19 & 0.19 & 0.16 \\
$\mathrm{TiO}_{2}$ & 0.16 & 0.20 & 0.14 & 0.15 & 0.16 & 0.16 & 0.19 \\
$\mathrm{Al}_{2} \mathrm{O}_{3}$ & 3.51 & 3.43 & 2.24 & 3.52 & 3.34 & 2.99 & 1.14 \\
$\mathrm{Cr}_{2} \mathrm{O}_{3}$ & 66.01 & 66.24 & 67.31 & 65.95 & 65.88 & 66.38 & 68.47 \\
$\mathrm{~V}_{2} \mathrm{O}_{3}$ & 0.56 & 0.59 & 0.53 & 0.55 & 0.54 & 0.64 & 0.58 \\
$\mathrm{FeO}_{\mathrm{MnO}}$ & 22.67 & 22.82 & 22.88 & 23.13 & 22.97 & 22.81 & 22.58 \\
$\mathrm{MgO}$ & 1.00 & 0.95 & 0.98 & 0.84 & 0.99 & 1.43 & 1.57 \\
\hline $\mathrm{Celkem}$ & 5.75 & 5.62 & 5.39 & 6.61 & 5.52 & 5.43 & 5.95 \\
\hline $\mathrm{Si}^{4+}$ & 99.77 & 99.69 & 99.61 & 99.99 & 99.59 & 100.03 & 99.64 \\
$\mathrm{Ti}^{4+}$ & 0.005 & 0.004 & 0.005 & 0.008 & 0.007 & 0.007 & 0.006 \\
$\mathrm{Al}^{3+}$ & 0.005 & 0.006 & 0.005 & 0.005 & 0.005 & 0.005 & 0.006 \\
$\mathrm{Cr}^{3+}$ & 0.145 & 0.141 & 0.094 & 0.145 & 0.139 & 0.124 & 0.048 \\
$\mathrm{~V}^{3+}$ & 1.830 & 1.833 & 1.884 & 1.825 & 1.832 & 1.834 & 1.930 \\
$\mathrm{Fe}^{2+}$ & 0.016 & 0.016 & 0.015 & 0.016 & 0.015 & 0.018 & 0.017 \\
$\mathrm{Mn}{ }^{2+}$ & 0.665 & 0.668 & 0.677 & 0.677 & 0.676 & 0.670 & 0.673 \\
$\mathrm{Mg}{ }^{2+}$ & 0.030 & 0.028 & 0.029 & 0.025 & 0.030 & 0.043 & 0.047 \\
\hline $\mathrm{Suma}$ kat. & 0.301 & 0.293 & 0.284 & 0.293 & 0.290 & 0.284 & 0.263 \\
\hline $\mathrm{Ulv}$ & 2.997 & 2.989 & 2.993 & 2.994 & 2.994 & 2.985 & 2.990 \\
$\mathrm{Mnch}$ & 0.5 & 0.6 & 0.5 & 0.5 & 0.5 & 0.5 & 0.6 \\
$\mathrm{Cls}$ & 3.0 & 2.8 & 2.9 & 2.5 & 3.0 & 4.3 & 4.7 \\
$\mathrm{Hrc}$ & 0.8 & 0.8 & 0.8 & 0.8 & 0.8 & 0.9 & 0.9 \\
$\mathrm{Mgch}$ & 7.3 & 7.1 & 4.7 & 7.3 & 7.0 & 6.2 & 2.4 \\
$\mathrm{Chr}$ & 30.1 & 29.3 & 28.4 & 29.3 & 29.0 & 28.4 & 26.3 \\
\hline $\mathrm{Celkem}$ & 57.5 & 57.8 & 61.3 & 58.7 & 58.9 & 58.9 & 62.9 \\
\hline
\end{tabular}

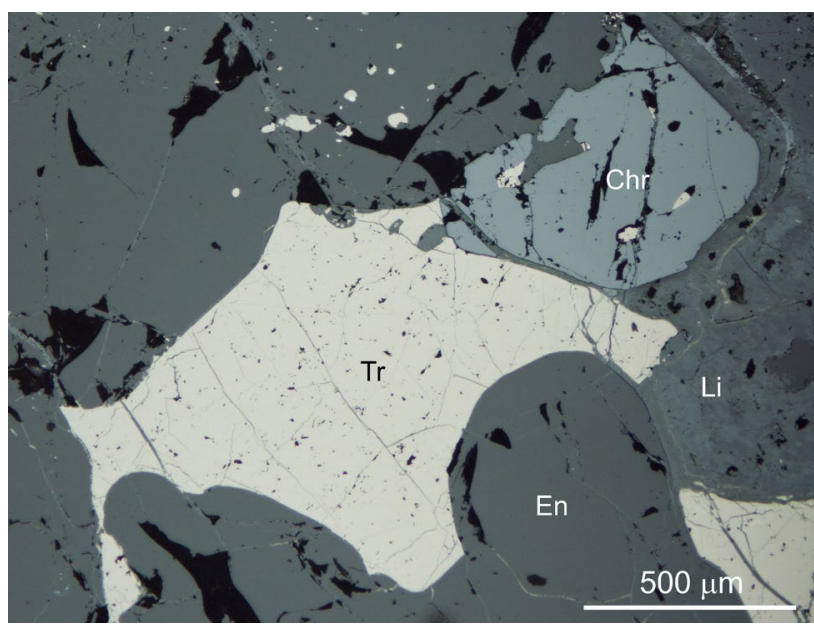

Obr. 19 Izometrické zrno chromitu (Chr) $v$ asociaci $s$ troilitem a enstatitem. Nábrus, odražené světlo, foto Z. Dolníček.

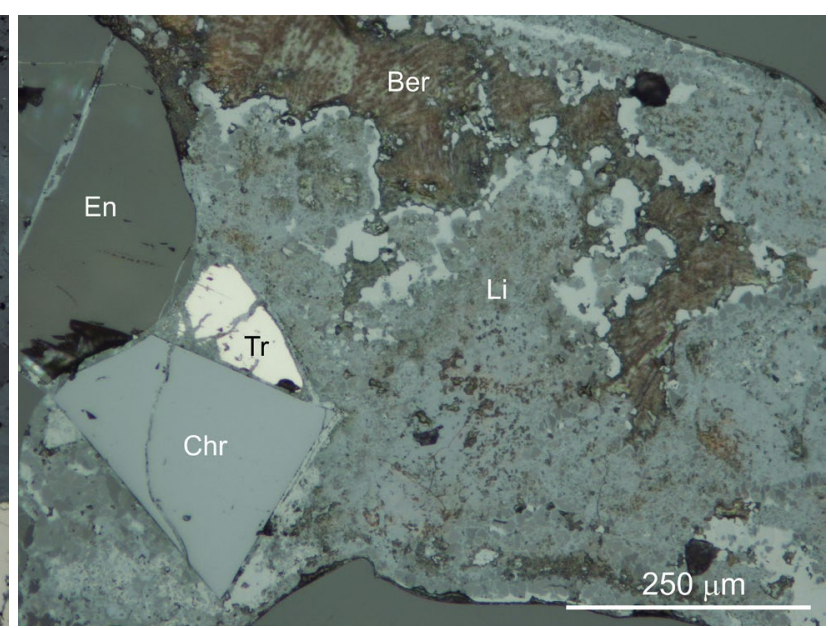

Obr. 20 Automorfni krystal chromitu $v$ asociaci s troilitem a enstatitem. Troilit je silně zatlačován limonitem, v jehož dutinách jsou výplně fosfátu blízkého beraunitu (Ber). Nábrus, odražené světlo, foto Z. Dolníček. 

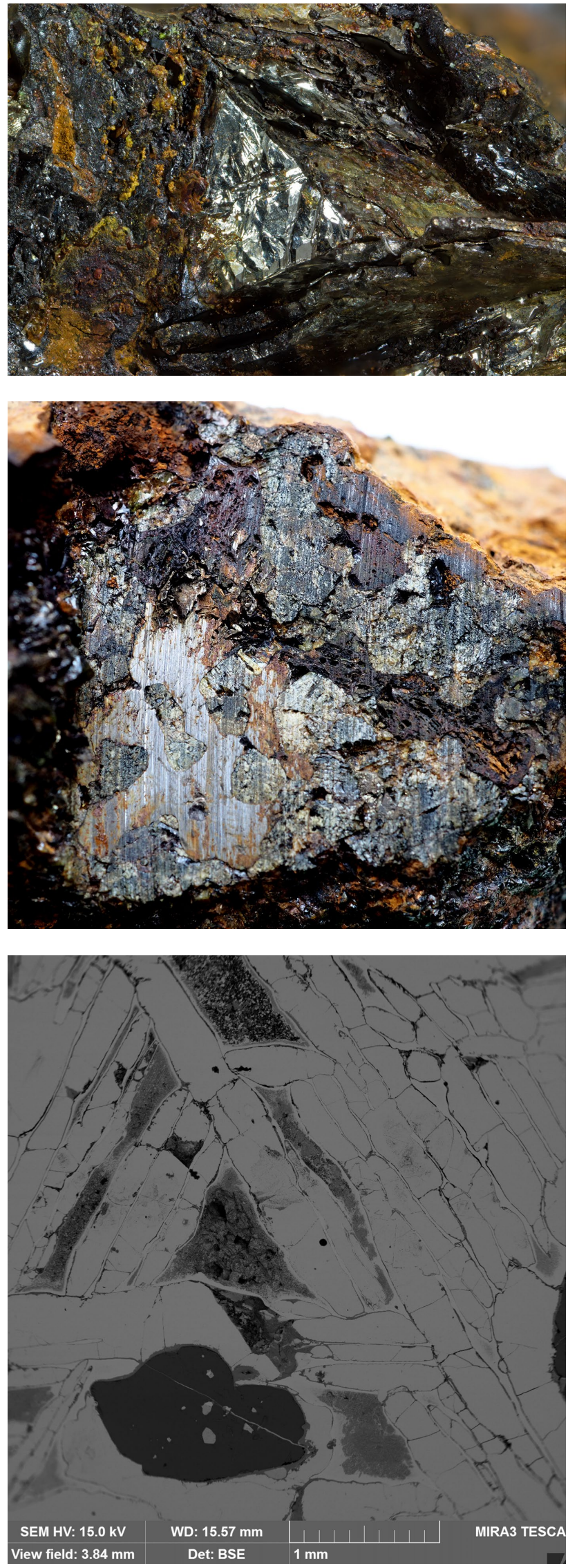

Obr. 23 Widmanstättenovy obrazce zachycené na nábrusu z prvního meteoritu, světle šedé lamely niklového železa, středně šedý limonit, tmavošedý enstatit $s$ drobnými zrny světle šedého troilitu, SEM foto O. Pour. né obsahy Fe (průměr $0.155 \mathrm{apfu}$ ) spolu s malými koncentracemi Mn (0.008 apfu), $\mathrm{Cr}(0.006 \mathrm{apfu}), \mathrm{Ca}(0.005$ apfu) a Al (0.004 apfu). Empirický vzorec enstatitu (průměr osmi bodových analýz) je na bázi tří atomů kyslíku možno vyjádřit jako $\left(\mathrm{Mg}_{0.82} \mathrm{Fe}_{0.15} \mathrm{Mn}_{0.01} \mathrm{Ca}_{0.01}\right)_{\Sigma=0.99}\left(\mathrm{SiO}_{3}\right)$. Zjištěná data jsou $v$ dobré shodě $s$ údaji publikovanými Ruzickou a Hutsonem (2006), respektive Riedem et al. (1974)

Další poměrně častou složkou studovaných nábrusů je tridymit, tvořící izometrická či mírně protažená 0.2 až 1 $\mathrm{mm}$ velká, nepravidelně omezená zrna. $\vee$ BSE obraze je chemicky homogenní (obr. 17). Vedle dominantního $\mathrm{SiO}_{2}$ (tab. 2) jsou prrítomny jen stopy $\mathrm{Al}_{2} \mathrm{O}_{3}, \mathrm{FeO}$ a $\mathrm{Na}_{2} \mathrm{O}$, jejichž koncentrace opět odpovídají obsahům zjištěným Ruzickou a Hutsonem (2006) či Riedem et al. (1974). V Ramanově spektru této fáze vystupují výrazné pásy při 353 , $307,435,211$ a $68 \mathrm{~cm}^{-1}$ (řazeno sestupně podle klesající intenzity) a dále méně výrazné pásy při 146, 672, 788 a $1076 \mathrm{~cm}^{-1}$ (obr. 18). V druhém vzorku byl navíc identifikován i pás při $111 \mathrm{~cm}^{-1}$ (střední intenzita) a naopak chybí pás při $672 \mathrm{~cm}^{-1}$ (obr. 18). Získaná spektra neodpovídají údajům pro tridymit publikovaným v databázi RRUFF. Přibližně shodné spektrum (s pásy při 210, 304, 349, 431, 799 a $1073 \mathrm{~cm}^{-1}$ ) je publikováno na webové stránce „Handbook of Raman spectra“ lyonské univerzity, s poznámkou, že jde o monoklinický tridymit. Zčásti podobné

Obr. 21 Zrno niklového železa z meteoritu Steinbach nalezeného na Glücksburgu, šírka záběru $6 \mathrm{~mm}$, foto B. Bureš.

Obr. 22 Detail průřezu částí prvního z nově nalezených meteoritů Steinbach na Glücksburgu se zrny enstatitu a niklového železa, šiřka záběru $2 \mathrm{~cm}$, foto $P$. Pauliš.

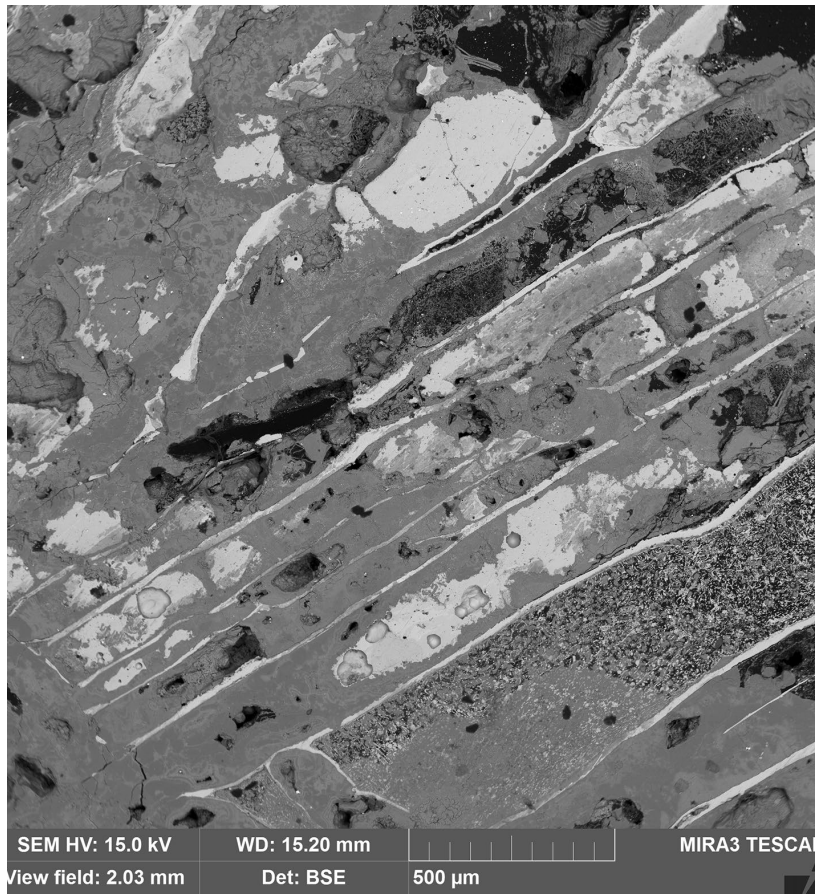

Obr. 24 Selektivní koroze železa s různým obsahem niklu na nábrusu z prvního meteoritu. Taenit zůstává zachován, zatímco kamacit a plessit jsou silně korodovány limonitem (šedý) a zůstávají pouze $v$ reliktech. SEM foto O. Pour 
spektrum pro monoklinický tridymit z impaktního kráteru Chesapeake Bay (USA) uvádějí i Jackson et al. (2011): s intenzivními pásy při 206, 282, 304, 351, 354, 433, 784, $792 \mathrm{~cm}^{-1}$ a slabým pásem při $410 \mathrm{~cm}^{-1}$. Monokrystalová rentgen-difrakční data potvrdila jednoklonnou symetrii $\mathrm{SiO}_{2}$ fáze $\mathrm{z}$ nově nalezeného meteoritu, s následujícími mřižkovými parametry: $a=18.521(7) \AA ⿻$, $b=5.0027(16)$ $\AA, c=23.821(10) \AA, \beta=105.79(4)^{\circ}, V=2124(1) \AA^{3}$. Mř́žzkové parametry byly zpřesněny ze 169 pozorovaných reflexí, z čehož bylo indexováno $85.21 \%$. Získané hodnoty jsou v souladu s publikovanými údaji mřížkových parametrů monoklinického tridymitu (viz tab. 3).

Akcesoricky je zastoupen chromit vytvářející 10 $300 \mu \mathrm{m}$ velká hypautomorfně až automorfně omezená zrna, někdy na styku s troilitem, jindy uzavřená v silikátech (obr. 19, 20). V BSE obraze je tento minerál homogenní. Při studiu jeho chemického složení (tab. 4) byly vedle dominantního $\mathrm{FeO}$ a $\mathrm{Cr}_{2} \mathrm{O}_{3}$ zjištěny i zvýšené obsahy $\mathrm{MgO}$ (průměr $0.296 \mathrm{apfu} \mathrm{Mg}$ ), $\mathrm{Al}_{2} \mathrm{O}_{3}$ (0.123 apfu Al) a $\mathrm{MnO}$ (0.034 apfu $\mathrm{Mn})$. Ve stopách byly ještě naměřeny $\mathrm{V}_{2} \mathrm{O}_{3}(0.017$ apfu $\mathrm{V}), \mathrm{SiO}_{2}(0.006$ apfu $\mathrm{Si})$ a $\mathrm{TiO}_{2}$ (0.006 apfu Ti). Průměrný empirický vzorec chromitu (průměr sedmi bodových analýz) je na bázi čtyř atomů kyslíku možno vyjádřit $\left(\mathrm{Fe}_{0.69} \mathrm{Mg}_{0.30} \mathrm{Mn}_{0.03}\right)_{\Sigma=1.02}\left(\mathrm{Cr}_{1.91} \mathrm{Al}_{0.12}\right.$ $\left.\mathrm{V}_{0.02}\right)_{\Sigma=2.05} \mathrm{O}_{4}$. Uvedené obsahy odpovídají 57.5 - 62.9 mol. $\%$ chromitové, 26.3 - 30.1 mol. \% magneziochromitové, 2.4 - 7.3 mol. \% hercynitové, 2.5 - 4.7 mol. \% manganochromitové, 0.8 - 0.9 mol. \% coulsonitové a 0.5 - 0.6 mol. \% ulvöspinelové komponenty (tab. 4). Z rámce hodnot uváděných v publikacích Ruzicky a Hutsona (2006) či Rieda et al. (1974) námi zjištěná data nijak nevybočují. Novou informací jsou obsahy $\mathrm{V}_{2} \mathrm{O}_{3}$, které výše uvedení autoři neuvádějí.

Přibližně třetinu řezné plochy meteoritu tvoří kompozičně nehomogenní niklem bohaté železo (obr. 21, 22), tvořící charakteristické Widmanstättenovy obrazce (obr. 23, 24, 25). Na jejich stavbě se podílejí podle starší terminologie tři složky s odlišným složením - kamacit, taenit a plessit. Kamacit (název IMA diskreditovaný, podle dnes platné mineralogické nomenklatury jde o železo), který obsahuje v průměru $7.13 \mathrm{hm}$. $\% \mathrm{Ni}$ a malé príměsi Co $(0.50 \mathrm{hm}$. \%) (tab. 5), tvoří zpravidla lišty různé síly. K obdobným hodnotám chemického složení došli také Dörfler et al. (1965). Lem lišt přibližně $15 \mu \mathrm{m}$ široký tvoří niklem bohaté železo taenit, který obsahuje $v$ průměru $28.04 \mathrm{hm}$. \% Ni a malé př́měsi Co $(0.26 \mathrm{hm}$. \%) (tab. 5). Prostory mezi lamelami niklového železa vyplňuje jemnozrnná směs kamacitu a taenitu, označovaná jako plessit. Vedle železa obsahuje v průměru $16.36 \mathrm{hm}$. \% $\mathrm{Ni}$ a malou príměs Co (0.37 hm. \%) (tab. 5). Limonitizací jsou v okrajových partiích meteoritu přednostně postihovány složky s nižším obsahem $\mathrm{Ni}$, tedy kamacit a plessit (obr. 24).

Poměrně časté jsou oválné 80 $\mu \mathrm{m}$ až přes $1 \mathrm{~mm}$ velké agregáty troilitu, které jsou v okrajových partiích meteoritu intenzivně zatlačovány limonitem (obr. 20). V odrazovém mikroskopu je troilit bronzově hnědý (obr. 19), při zkřrižených nikolech slabě anizotropní. Jeho empirický vzorec (tab. 6) (průměr sedmi bodových analýz) je na bázi $1 \mathrm{~S}$ možno vyjádřit jako $\left(\mathrm{Fe}_{0.96} \mathrm{Cr}_{0.01}\right)_{\Sigma=0.97} \mathrm{~S}$. Vedle dominantního železa a síry je $v$ troili- tu zastoupen v malém množství $\mathrm{Cr}$ (průměr $0.011 \mathrm{apfu}$ ). Obdobnou koncentraci $\mathrm{Cr}(0.61 \%)$ naměřili $v$ troilitu ze Steinbachu Dörfler et al. (1965).

Vzácnou akcesorií meteoritu jsou fosfidy železa a niklu schreibersit a niklfosfid, tvořící nepravidelná zrna o rozměrech 40 - $200 \mu \mathrm{m}$. Často vytvářejí tenké neprů-

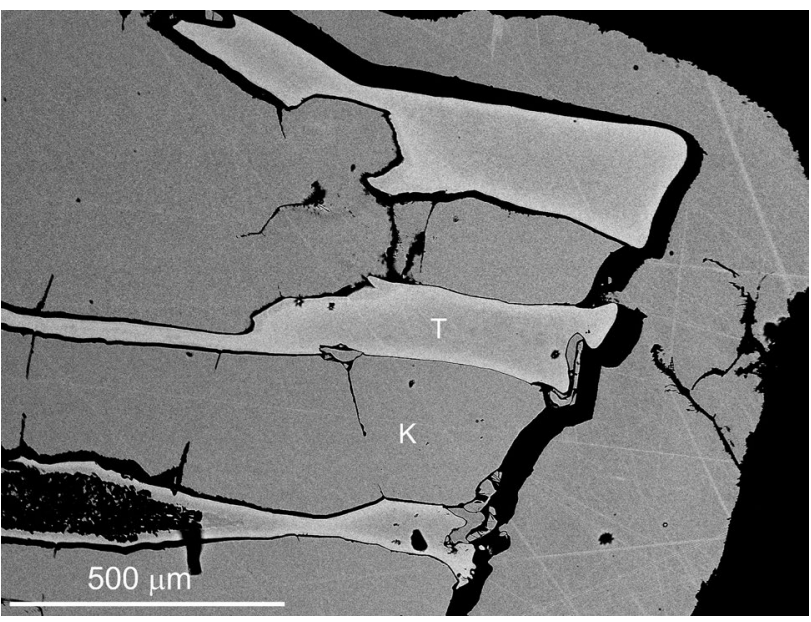

Obr. 25 Kompozičně zonální lišty taenitu $(T)$ uzavřené $v$ homogenním kamacitu (K). BSE foto Z. Dolníček.

Tabulka 5 Chemické složení niklového železa z nově nalezeného meteoritu ( $\mathrm{hm}$. \%).

\begin{tabular}{rrrrrr}
\hline An. č. & fáze & $\mathrm{Fe}$ & $\mathrm{Ni}$ & Co & Celkem \\
\hline 1 & kamacit & 91.49 & 7.27 & 0.55 & 99.31 \\
2 & kamacit & 92.08 & 6.02 & 0.42 & 98.52 \\
3 & kamacit & 91.13 & 7.43 & 0.51 & 99.07 \\
4 & kamacit & 90.70 & 7.40 & 0.52 & 98.62 \\
5 & kamacit & 91.65 & 7.23 & 0.46 & 99.34 \\
6 & kamacit & 91.57 & 7.22 & 0.49 & 99.28 \\
7 & kamacit & 91.06 & 7.34 & 0.53 & 98.93 \\
8 & taenit & 74.72 & 25.07 & 0.62 & 100.41 \\
9 & taenit & 68.30 & 30.30 & 0.14 & 98.74 \\
10 & taenit & 70.76 & 27.60 & 0.31 & 98.67 \\
11 & taenit & 68.57 & 30.13 & 0.13 & 98.83 \\
12 & taenit & 71.53 & 27.19 & 0.18 & 98.90 \\
13 & taenit & 70.04 & 28.62 & 0.19 & 98.85 \\
14 & taenit & 71.21 & 27.38 & 0.23 & 98.82 \\
15 & plessit & 83.86 & 14.63 & 0.42 & 98.91 \\
16 & plessit & 81.66 & 16.72 & 0.38 & 98.76 \\
17 & plessit & 80.84 & 17.73 & 0.31 & 98.88 \\
\hline
\end{tabular}

Tabulka 6 Chemické složení troilitu z nově nalezeného meteoritu. Obsahy prvků jsou v hm. \%, hodnoty apfu jsou vyjádřeny na základ 1 atomu síry.

\begin{tabular}{lrrrrrrr}
\hline An. č. & 1 & 2 & 3 & 4 & 5 & 6 & 7 \\
\hline $\mathrm{Fe}$ & 61.94 & 61.13 & 61.58 & 61.41 & 61.85 & 61.85 & 61.67 \\
$\mathrm{Cr}$ & 0.96 & 1.22 & 0.48 & 0.51 & 0.53 & 0.52 & 0.54 \\
$\mathrm{~S}$ & 36.81 & 36.58 & 36.44 & 36.49 & 36.82 & 36.90 & 37.04 \\
\hline Celkem & 99.71 & 98.93 & 98.50 & 98.41 & 99.20 & 99.27 & 99.25 \\
\hline $\mathrm{Fe}$ & 0.966 & 0.960 & 0.970 & 0.966 & 0.964 & 0.962 & 0.956 \\
$\mathrm{Cr}$ & 0.016 & 0.020 & 0.008 & 0.009 & 0.009 & 0.001 & 0.005 \\
\hline Suma kat. & 0.982 & 0.980 & 0.978 & 0.975 & 0.973 & 0.963 & 0.961 \\
\hline $\mathrm{S}$ & 1.000 & 1.000 & 1.000 & 1.000 & 1.000 & 1.000 & 1.000 \\
\hline
\end{tabular}


běžné lemy kolem agregátů troilitu či kovového železa (obr. 26). Vůči zvětrávání jsou mnohem odolnější než troilit a slabě niklové železo. V odraženém světle jsou světle krémové, žlutější než železo a světlejší než troilit. Anizotropie není patrná. $\mathrm{Fe}$ a $\mathrm{Ni}$ jsou zastoupeny zhruba ve stejném množství. Část analýz s mírnou převahou Fe

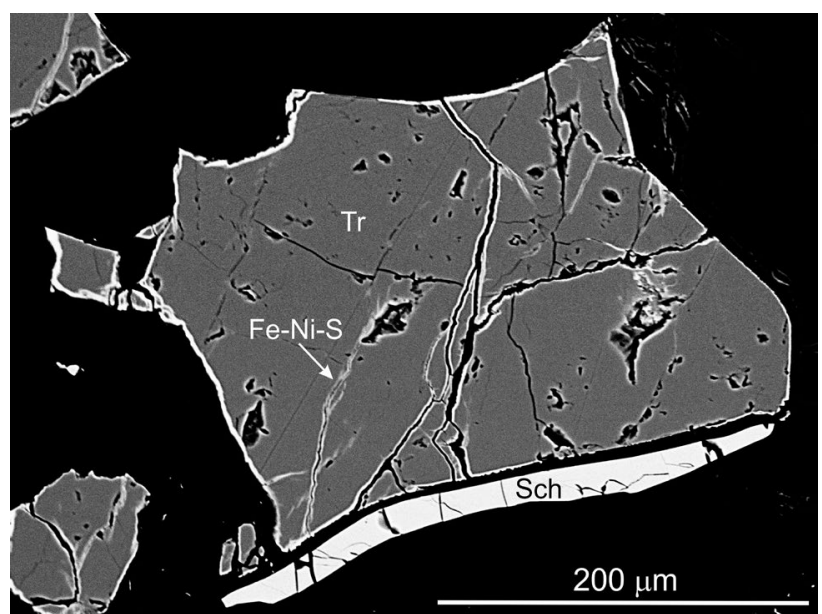

Obr. 26 Lem schreibersitu (Sch) okolo agregátu troilitu. $\checkmark$ troilitu jsou ojedinělé vlasové žilky Fe-Ni sulfidů (Fe-Ni-S). BSE foto Z. Dolníček.

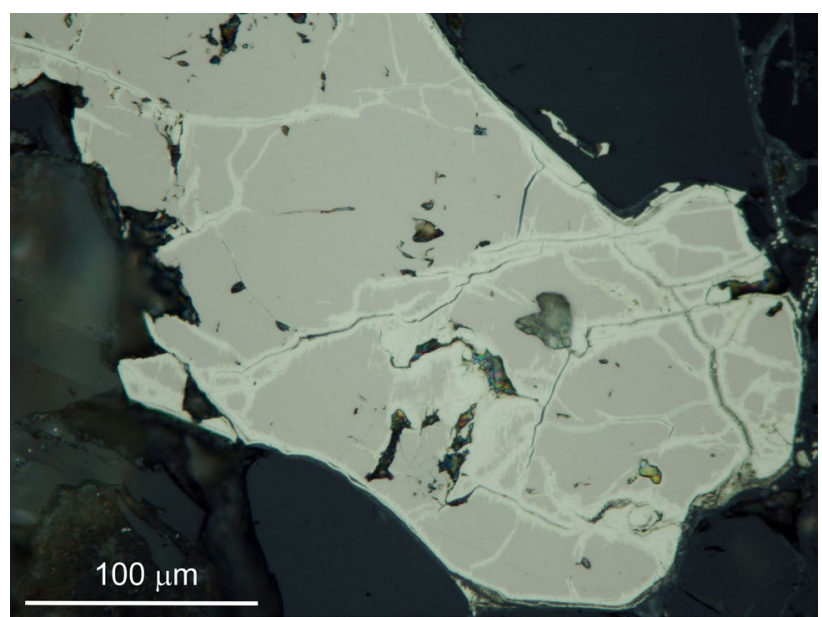

Obr. 27 Okrouhlý agregát troilitu (bronzový), hojně pronikaný žilkami Fe-Ni sulfidů (krémové). Nábrus, odražené světlo, foto Z. Dolníček.

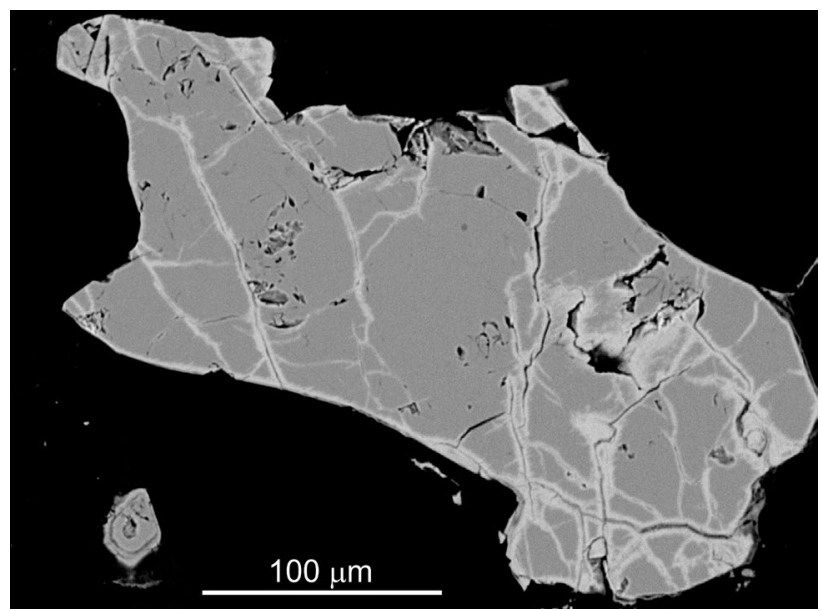

Obr. 28 Troilit s žilkami Fe-Ni sulfidů z obrázku 27 v obraze BSE. Foto Z. Dolníček. odpovídá schreibersitu, jehož empirický vzorec (tab. 7) (průměr čtyř bodových analýz) je na bázi $1 \mathrm{P}$ možno vyjádřit jako $\left(\mathrm{Fe}_{1.61} \mathrm{Ni}_{1.44}\right)_{\Sigma=3.05} \mathrm{P}$, část analýz s mírnou převahou Ni odpovídá niklfosfidu, jehož empirický vzorec (tab. 7) (průměr tří bodových analýz) je na bázi $1 \mathrm{P}$ možno vyjádřit jako $\left(\mathrm{Ni}_{1.61} \mathrm{Fe}_{1.42}\right)_{\Sigma=3.03} \mathrm{P}$. Vedle těchto kationů je $v$ obou prípadech v malém množství zastoupen Co (0.003 apfu).

Mimo těchto minerálních složek, které již byly $v$ minulosti $v$ meteoritech Steinbach zjištěny, byly nově dále identifikovány Fe-Ni sulfidy. Tvoří drobné, maximálně 3 $\mu m$ široké, náhodně orientované, průběžné i neprůběžné žilky $v$ některých zrnech troilitu. $V$ některých případech žilky pronikají i po štěpnosti zrn troilitu. V odraženém světle jsou světle krémové, světlejší než okolní troilit a také s vyšší odrazností, než má okolní troilit (obr. 27). Anizotropii nelze odpovědně posoudit vzhledem $\mathrm{k}$ velmi malým rozměrům a asociaci s anizotropním troilitem. Charakter výskytu a vzhled v odrazovém mikroskopu velmi upomínají na pyrit či markazit, vznikající supergenní přeměnou pyrhotinu. V BSE obraze jsou Fe-Ni sulfidy světlejší, než okolní troilit (obr. 26, 28). Vedle dominantního železa, niklu a síry jsou $v$ nich zastoupeny $v$ proměnlivém množství Cu (pod mezí stanovitelnosti až 6.6 hm. \%) a v menší míře i Co $(0.13-3.38$ hm. \%) a Cr $(0.15-0.48$ hm. \%; tab. 8). Chemické složení výrazně kolísá, zejména při porovnání složení žilek nacházejících se $v$ různých zrnech troilitu. Poměr $\mathrm{Fe} /(\mathrm{Fe}+\mathrm{Ni})$ kolísá mezi 0.11 a 0.66 a poměr kationtů kovů vůči aniontům mezi 1.02 a 1.49 (obr. 29). Většina analýz nevykazuje stechiometrické složení, ale odpovídá Ni-bohatým binárním směsím troilit-godlevskit a troilit-heazlewoodit (obr. 29). Tato zjištění jsou zajímavá vzhledem ke skutečnosti, že analýzy postihly „čistou“ fázi žilek, podle mikroskopického ověření pozice analyzovaných míst nekontaminovanou okolním hostitelským troilitem. Ani při velkém zvětšení optického a elektronového mikroskopu není pozorovatelná fázová nehomogenita studovaných žilek. Tyto žilky tedy patrně představují submikroskopické směsi uvedených $\mathrm{Ni}-(\mathrm{Fe})$ sulfidů a troilitu. Dvě získané analýzy mají i složení blížící se milleritu a Fe-analogu heazlewooditu (obr. 29). Mechanismus vzniku těchto niklem bohatých sulfidických žilek v troilitu není jasný. Snad by mohlo jít o výsledek dynamometamorfózy hmoty meteoritu při impaktech, při níž došlo k vyloučení „nečistot“ původně přítomných $v$ hostitelském troilitu do trhlin $\vee$ podobě samostatných minerálů. Uvedené možnosti ovšem protiřečí skutečnost, že tyto žilky nebyly zjištěny $v$ dalších dosud nalezených kusech meteoritů Steinbach - samožrejmě pokud ovšem ke vzniku žilek nedošlo jen u určitého fragmentu meteoritu až v okamžiku jeho dopadu na povrch Země. Druhou hypotetickou možností je „cementačni“" původ žilek, podmíněný přínosem Ni uvolněného během supergenního rozkladu okrajových částí meteoritu po jeho dopadu na zemský povrch.

Vzhledem k tomu, že studované fragmenty meteoritu byly po dopadu vystaveny po dobu několika staletí působení povětrnostních a klimatických činitelů, je jejich několik mm silná povrchová vrstva tvořena především (hydro) oxidy železa - limonitem. $V$ navětralých partiích meteoritu zatlačuji (hydro)oxidy železa zejména kovové železo a troilit. I všudypřítomné vlasové trhlinky ve všech ostatních přitomných minerálních fázích jsou jimi vyplněny (obr. 17). Limonit je $v$ odrazovém mikroskopu i v BSE obraze často detailně zonální, přičemž se jednotlivé zóny liší pravděpodobně jen stupněm hydratace ( $v$ EDS spektrech z různých zón nebyly zjištěny žádné zásadní rozdíly ve složení). Vedle limonitu byl chemicky analyzován i fosfát 
železa, tvořící místy v limonitu výplně volných dutin. Daná fáze vytváří bud' úplné výplně dutin (obr. 20, 30) nebo narůstá na jejich stěny $v$ podobě automorfních prizmatických krystalů o velikosti až $0.1 \mathrm{~mm}$. Na BSE snímcích je velmi dobře patrná výborná štěpnost dané fáze podle jednoho systému štěpných trhlin paralelního $s$ protažením krystalů. $V$ BSE obraze Ize někdy pozorovat nepravidelná tmavší jádra agregátů, lemovaná světlejším okrajem (obr. 30). Chemické složení v BSE tmavší fáze (tab. 9 , analýzy 1 - 4) je blízké beraunitu, který obsahuje vedle $\mathrm{Fe}$ a $\mathrm{P}$ i průběžný zvýšený podíl Ni (0.09- 0.55 apfu), Co (max. $0.04 \mathrm{apfu}$ ) a ojediněle i Mn (max. 0.25 apfu). U některých analýz Ize již konstatovat převahu $\mathrm{Ni}$ nad $\mathrm{Fe}$ $\checkmark$ pozici dvojvalentního kovu (tab. 9 , analýzy 3 a 4), a tedy by $v$ tom prípadě mělo jít o nový minerál, dosud nepopsaný $\mathrm{Fe}^{3+}-\mathrm{Ni}^{2+}$ analog beraunitu. Pokus o potvrzení identifikace této fáze pomocí Ramanovy spektroskopie nebyl úspěšný, fáze působením laserového paprsku rychle degraduje a získané spektrum se vyznačuje vysokým pozadím. V BSE obraze světlejší okrajové partie agregátů se vyznačují vyšším obsahem $\mathrm{Fe}$ a nižším obsahem $P$, než má výše charakterizovaný beraunit, a také zvýšeným obsahem S (max. 0.20 apfu) a často i As (max. 0.08 apfu; tab. 9, analýzy 5 a 6). Jde pravděpodobně o partie postižené začínající supergenní přeměnou. Ojediněle byly zaznamenány i pseudomorfózy limonitu po daném
Tabulka 7 Chemické složení schreibersitu (analýzy 1 - 4) a niklfosfidu (analýzy 5 - 7) z nově nalezeného meteoritu. Obsahy prvkü jsou v hm. \%, hodnoty apfu jsou vyjádřeny na základ 1 atomu fosforu.

\begin{tabular}{lrrrrrrr}
\hline An. č. & 1 & 2 & 3 & 4 & 5 & 6 & 7 \\
\hline $\mathrm{Fe}$ & 41.87 & 44.07 & 43.69 & 43.07 & 37.25 & 37.06 & 40.59 \\
$\mathrm{Co}$ & 0.08 & 0.12 & 0.07 & bdl & 0.08 & 0.11 & 0.14 \\
$\mathrm{Ni}$ & 42.16 & 39.72 & 40.30 & 40.37 & 47.39 & 46.53 & 43.26 \\
$\mathrm{P}$ & 14.79 & 14.92 & 14.97 & 14.93 & 15.07 & 14.94 & 14.92 \\
\hline Celkem & 98.90 & 98.83 & 99.03 & 98.79 & 99.79 & 98.64 & 98.91 \\
\hline $\mathrm{Fe}$ & 1.571 & 1.638 & 1.619 & 1.615 & 1.376 & 1.376 & 1.509 \\
$\mathrm{Co}$ & 0.003 & 0.004 & 0.003 & bdl & 0.003 & 0.004 & 0.005 \\
$\mathrm{Ni}$ & 1.527 & 1.404 & 1.422 & 1.427 & 1.659 & 1.643 & 1.530 \\
\hline Suma kat. & 3.101 & 3.046 & 3.044 & 3.042 & 3.038 & 3.023 & 3.044 \\
\hline $\mathrm{P}$ & 1.000 & 1.000 & 1.000 & 1.000 & 1.000 & 1.000 & 1.000 \\
\hline
\end{tabular}

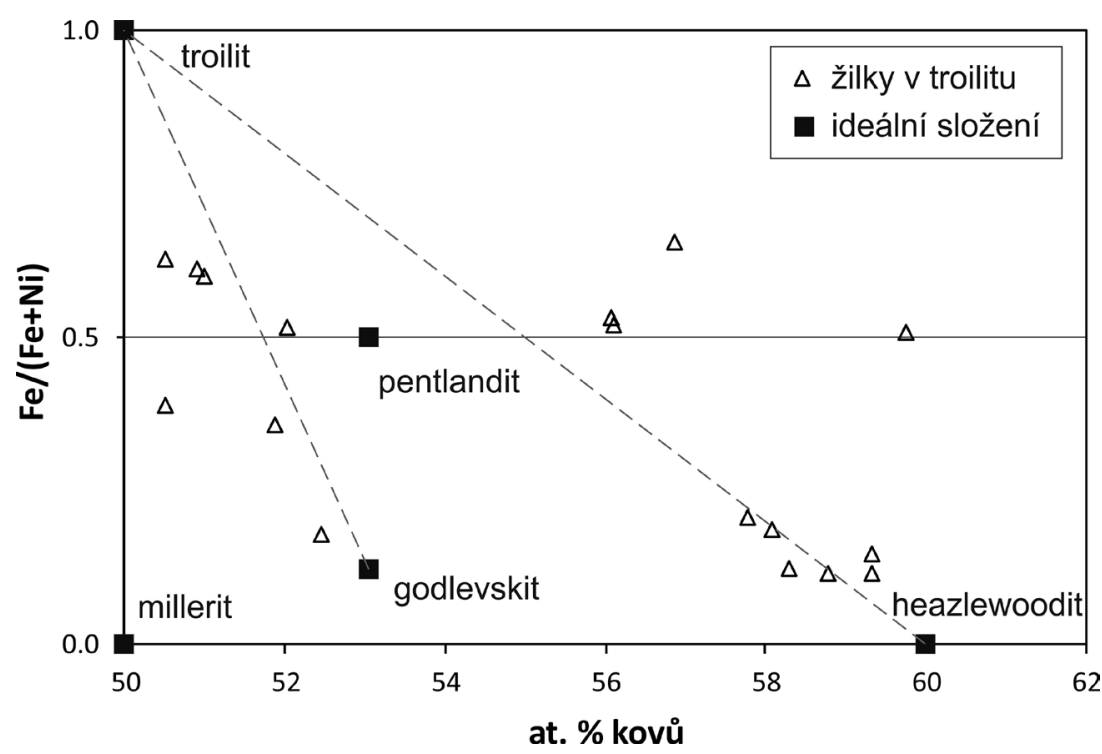

Obr. 29 Variace $v$ chemickém složení Fe-Ni sulfidů. Čárkované linie vymezují složení směsí godlevskit-troilit a heazlewoodit-troilit.

Tabulka 8 Chemické složení Fe-Ni sulfidů z nově nalezeného meteoritu. Obsahy prvků jsou v hm. \% (horní část tabulky) a at. \% (spodní část tabulky).

\begin{tabular}{|c|c|c|c|c|c|c|c|c|c|c|c|c|c|c|}
\hline n. č. & 1 & 2 & 3 & 4 & 5 & 6 & 7 & 8 & 9 & 10 & 11 & 12 & 13 & \\
\hline$e$ & .47 & 15 & .54 & 69 & 66 & 54 & .00 & .92 & .15 & .86 & 44 & 24 & .24 & 10.35 \\
\hline & 96 & & 11 & 28 & & & & & & & & & & \\
\hline o & 31 & 0.27 & 1.31 & 1.53 & 97 & 38 & 0.39 & 0.13 & 0.15 & 3.58 & 0.27 & 0.36 & 0.03 & .32 \\
\hline $\mathrm{u}$ & 49 & bdl & 0.05 & 0.05 & bdl & 0.05 & 0.58 & 0.46 & 0.37 & 1.87 & 0.80 & 1.55 & 1.95 & .63 \\
\hline & & & 18 & & & & 18 & & 37 & & & & .48 & .46 \\
\hline & .94 & .26 & 28.27 & 28.45 & 29 & 28.12 & 29.76 & 30.69 & 27.11 & 33.97 & 35.27 & 34.90 & 33.48 & 33.53 \\
\hline & bdl & 05 & 0.05 & 0.05 & 04 & bdl & .06 & .09 & .08 & bdl & bdl & 0.07 & .07 & 0.05 \\
\hline & bdl & 08 & .05 & 0.06 & 7 & 07 & bdl & bdl & bdl & 0.06 & 0.05 & 0.05 & bdl & 0.03 \\
\hline 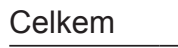 & .45 & .89 & .56 & 99.29 & 3.47 & 9.86 & 99.42 & 100.71 & 9.1 & 100.24 & 99.31 & 99.21 & 3.83 & 1.33 \\
\hline & 22 & 67 & .65 & 64 & 32 & 7.26 & 36.59 & 29.49 & 29.93 & 16.93 & 30.93 & 18.89 & 24.86 & 8.45 \\
\hline & 15 & 50.30 & 46.16 & 71 & 22 & 55 & 11 & 25.79 & 29.10 & 30.47 & 18.39 & 29.81 & 23.14 & 38.62 \\
\hline & 0.24 & .22 & 05 & 1.23 & 79 & 31 & 31 & 10 & 0.12 & 75 & 0.21 & 0.28 & .02 & 0.25 \\
\hline & 6 & bdl & 0.04 & 0.04 & bdl & 04 & 0.42 & 0.33 & 0.28 & 3 & 0.57 & 1.11 & .58 & .74 \\
\hline$r$ & 0.24 & .14 & 0.16 & 0.16 & 16 & 0.14 & 0.43 & 0.35 & 0.34 & 0.39 & 0.40 & 0.43 & .42 & .40 \\
\hline um & 50.91 & 9.33 & 58.07 & 57.78 & 3.79 & 8.29 & 56.86 & 56.07 & 59.76 & 51.88 & 50.49 & 50.50 & 52.02 & 52.45 \\
\hline & .09 & 40.55 & 1.84 & 42.13 & & 1.62 & 43.12 & 43.90 & 40.21 & 8.04 & 9.44 & 49.41 & 47.95 & 47.49 \\
\hline & bdl & 0.02 & 0.02 & 0.02 & $\angle$ & Dal & 0.02 & 0.03 & 0.03 & bdl & bdl & 0.02 & 0.03 & .02 \\
\hline & bdl & 0.11 & 0.07 & 0.08 & 0.10 & 0.09 & bdl & bdl & bdl & 0.08 & 0.06 & .06 & bdl & 0.04 \\
\hline . & 49.09 & 40.67 & 41.93 & 42.22 & 1.21 & 1.71 & 3.14 & 43.93 & 40.24 & 48.12 & 49.51 & 49.50 & 47.98 & 47.55 \\
\hline $\mathrm{e} /(\mathrm{Fe}+\mathrm{Ni})$ & 0.61 & 0.15 & 0.19 & 0.21 & 0.11 & 0.13 & 0.66 & 0.53 & 0.51 & 0.36 & 0.63 & 0.39 & 0.04 & 0.1 \\
\hline
\end{tabular}


fosfátu, které již neobsahovaly žádný fosfor, ale značně zvýšené obsahy Ni (11.1 - 19.0 hm. \% NiO) a S (6.5 - 7.7 hm. \% $\mathrm{SO}_{3}$ ).

\section{Radionuklidové složení nově nalezeného meteoritu}

Vzhledem $\mathrm{k}$ tomu, že terestrické stáří meteoritu Steinbach je odhadováno na několik stovek let, bylo možné z kosmogenních radionuklidů gamaspektrometricky analyzovat pouze radionuklid ${ }^{26} \mathrm{Al}$, který má poločas přeměny 717000 roků. Z primordiálních radionuklidů byly analyzovány ${ }^{40} \mathrm{~K},{ }^{232} \mathrm{Th}$ a ${ }^{238} \mathrm{U}$.

Na obrázku 31 je znázorněné gama-spektrum meteoritu Steinbach z Glücksburgu, ve kterém Ize zřetelně identifikovat kosmogenní radionuklid ${ }^{26} \mathrm{Al}$ (což je současně i jednoznačný důkaz toho, že se jedná o meteorit), primordiální radionuklid ${ }^{40} \mathrm{~K}$, spolu $\mathrm{S}$ primordiálními radionuklidy ${ }^{232} \mathrm{Th}$ (pomocí jeho rozpadového produktu ${ }^{208} \mathrm{TI}$ ) a ${ }^{238} \mathrm{U}$ (pomocí jeho rozpadového produktu ${ }^{214} \mathrm{Bi}$ ). Naměřené aktivity primordiálních radionuklidů odpovídají $0.8 \mathrm{~Bq} / \mathrm{kg}$ pro ${ }^{40} \mathrm{~K}, 0.4 \mathrm{~Bq} / \mathrm{kg}$ pro ${ }^{232} \mathrm{Th}$ a $0.3 \mathrm{~Bq} / \mathrm{kg}$ pro ${ }^{238} \mathrm{U}$. Tyto naměřené hodnoty odpovídají príbližně tomu, co Ize očekávat u tohoto typu meteoritů.

Naměřená aktivita ${ }^{26} \mathrm{Al} v$ nově nalezeném fragmentu meteoritu Steinbach je $0.40 \pm 0.06 \mathrm{~Bq} / \mathrm{kg}$. Z této hodnoty Ize na základě Monte Carlo simulací (Masarik, Ree-

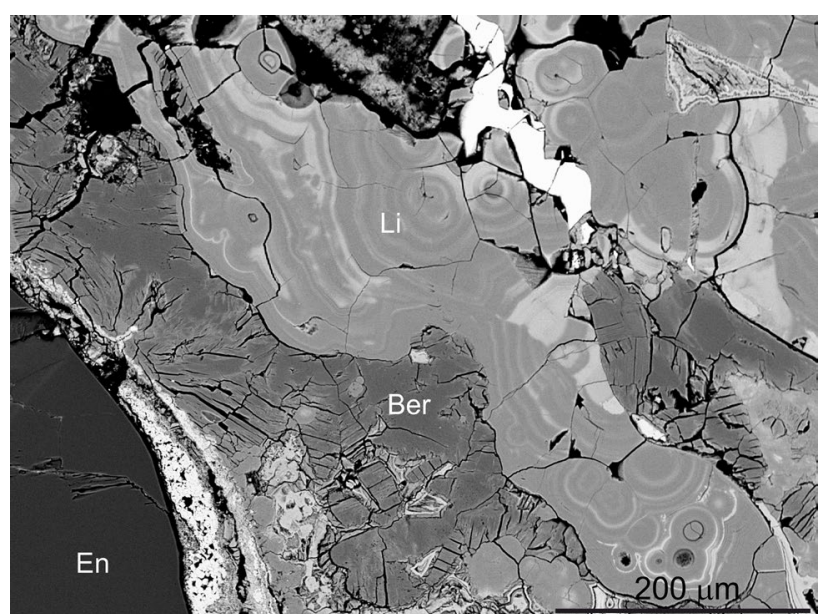

Obr. 30 Zonální limonit, vzniklý zvětráváním železa, v jehož dutinách jsou výplně fosfátu blízkého beraunitu. BSE foto Z. Dolníček.

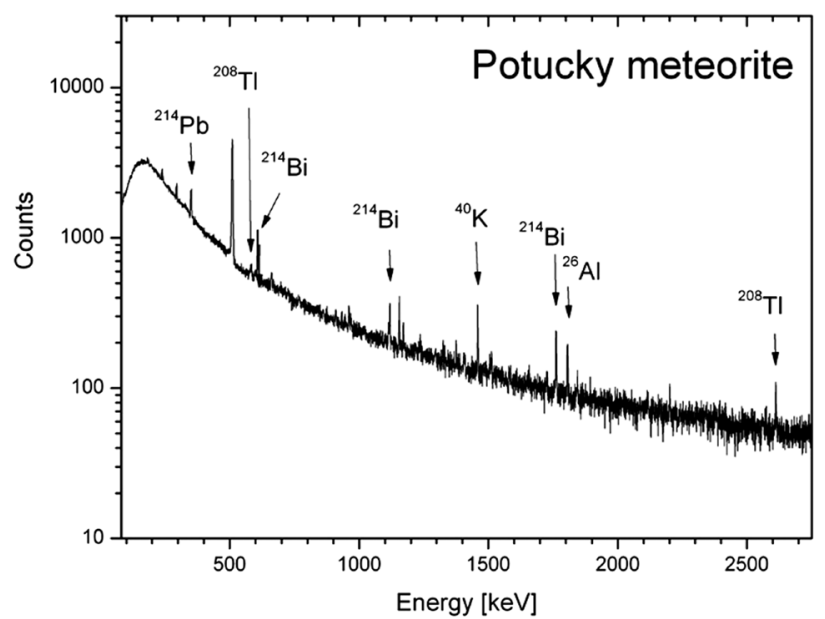

Obr. 31 Naměřené gama-spektrum meteoritu Steinbach nově nalezeného na Glücksburgu (spolu s pozadím HPGe detektoru). Celková doba měření byla 22.2 dní. dy 1994; Leya, Masarik 2009) po příslušných korekcích vzhledem $\mathrm{k}$ chemického složení meteoritu a jeho silikátové a železné složce odvodit, že tento fragment byl stíněn a nacházel se ve vnitřních částech meteoroidu.

Radionuklid ${ }^{26} \mathrm{Al}$ má príliš krátký poločas přeměny pro to, abychom z něho mohli stanovit dobu vystavení kosmickému záření (tzv. radiační stárí) tohoto meteoritu. Proto byl $\mathrm{k}$ tomuto účelu využit radionuklid ${ }^{40} \mathrm{~K}$, který má poločas přeměny $1.25 \times 10^{9}$ roků. $V$ prrípadě železných meteoritů má zdroj ${ }^{40} \mathrm{~K}$ vedle primordiálního i kosmogenní původ. Jestliže předpokládáme, že $50 \%$ naměřené aktivity ${ }^{40} \mathrm{~K}$ je kosmogenního pưvodu, potom by doba vystavení tohoto meteoritu kosmickému záření mohla odpovídat cca $70 \pm 30$ miliónů let. Pro kamenno-železné meteority je střední radiační stáŕí kolem 90 miliónů let, přičemž odhadem asi u $20 \%$ z nich je tato hodnota nižší, pohybující se kolem 70 miliónů let (Eugster et al. 2006). Přestože námi zjištěná doba vystavení kosmickému záření má značný rozptyl, odpovídá této koncepci.

Tyto výsledky představují první údaje o radionuklidech obsažených $v$ meteoritu Steinbach a nelze je zatím porovnat $s$ dalšími naměřenými daty. $V$ současnosti se připravují destruktivní analýzy ${ }^{10} \mathrm{Be}$ a ${ }^{14} \mathrm{C}$ pomocí urychlovačové hmotnostní spektrometrie a izotopové analýzy vzácných plynů. Výsledky těchto analýz by měly stanovit terestrické stáŕí tohoto meteoritu i upřesnit jeho předatmosférické rozměry i dobu vystavení kosmickému záření.

Tabulka 9 Přiklady chemického složení fosfátu blízkého beraunitu z nově nalezeného meteoritu. Obsahy oxidů jsou $\mathrm{v} \mathrm{hm}$. \%, hodnoty apfu jsou vyjádřeny na základ 4 atomů $P+A s+S$ a 1 atomu dvojvalentního kationtu. Obsah vody je dopočten ze stechiometrie. j - jádro agregátu, o - okraj agregátu.

\begin{tabular}{lrrrrrr}
\hline An. č. & $1-\mathrm{j}$ & $2-\mathrm{j}$ & $3-\mathrm{j}$ & $4-\mathrm{j}$ & $5-\mathrm{o}$ & $6-\mathrm{o}$ \\
\hline $\mathrm{SO}_{3}$ & bdl & bdl & bdl & bdl & 0.44 & 1.53 \\
$\mathrm{P}_{2} \mathrm{O}_{5}$ & 27.97 & 27.45 & 29.56 & 28.28 & 28.74 & 28.07 \\
$\mathrm{As}_{2} \mathrm{O}_{5}$ & bdl & bdl & bdl & 0.31 & bdl & 0.99 \\
$\mathrm{Fe}_{2} \mathrm{O}_{3}$ & 39.63 & 38.82 & 41.52 & 40.54 & 43.97 & 43.85 \\
$\mathrm{FeO}_{\mathrm{OaO}}$ & 4.41 & 4.23 & 3.45 & 2.61 & 4.60 & 2.66 \\
$\mathrm{CaO}$ & 0.09 & 0.05 & bdl & bdl & 0.07 & 0.10 \\
$\mathrm{MnO}$ & 1.75 & bdl & 0.12 & bdl & bdl & bdl \\
$\mathrm{NiO}$ & 0.64 & 2.59 & 3.93 & 4.13 & 2.58 & 4.48 \\
$\mathrm{CoO}$ & 0.17 & 0.16 & 0.13 & 0.33 & 0.21 & 0.31 \\
$\mathrm{CuO}$ & bdl & bdl & bdl & 0.33 & bdl & 0.23 \\
$\mathrm{H}_{2} \mathrm{O}$ & 11.54 & 11.32 & 12.19 & 11.74 & 12.02 & 12.39 \\
\hline $\mathrm{Celkem}$ & 86.20 & 84.62 & 90.90 & 88.27 & 92.63 & 94.61 \\
\hline $\mathrm{S}^{6+}$ & bdl & bdl & bdl & bdl & 0.054 & 0.181 \\
$\mathrm{P}^{5+}$ & 4.000 & 4.000 & 4.000 & 3.973 & 3.946 & 3.738 \\
$\mathrm{As}^{5+}$ & bdl & bdl & bdl & 0.027 & bdl & 0.081 \\
\hline $\mathrm{Subtot}^{2}$ & 4.000 & 4.000 & 4.000 & 4.000 & 4.000 & 4.000 \\
\hline $\mathrm{Fe}^{3+}$ & 5.037 & 5.028 & 4.993 & 5.062 & 5.366 & 5.190 \\
$\mathrm{Fe}^{2+}$ & 0.623 & 0.609 & 0.461 & 0.362 & 0.624 & 0.350 \\
$\mathrm{Ca}^{2+}$ & 0.016 & 0.009 & bdl & bdl & 0.012 & 0.017 \\
$\mathrm{Mn}^{2+}$ & 0.250 & bdl & 0.016 & bdl & bdl & bdl \\
$\mathrm{Ni}^{2+}$ & 0.087 & 0.359 & 0.505 & 0.551 & 0.337 & 0.567 \\
$\mathrm{Co}^{2+}$ & 0.023 & 0.022 & 0.017 & 0.044 & 0.027 & 0.039 \\
$\mathrm{Cu}^{2+}$ & bdl & bdl & bdl & 0.041 & bdl & 0.027 \\
\hline $\mathrm{Suma} \mathrm{Me}^{2+}$ & 1.000 & 0.999 & 0.999 & 0.999 & 1.000 & 1.000 \\
\hline $\mathrm{Suma} \mathrm{kat.}^{2+}$ & 6.037 & 6.026 & 5.992 & 6.061 & 6.366 & 6.190 \\
$\mathrm{H}_{2} \mathrm{O}$ & 4.000 & 4.000 & 4.000 & 4.000 & 4.000 & 4.000 \\
$\mathrm{OH}^{-}$ & 5.002 & 4.996 & 4.996 & 4.995 & 5.004 & 5.001 \\
\hline & & & & & &
\end{tabular}


Obr. 32 Místo dopadu meteoritu Steinbach $v$ Potůčkách (Breitenbachu), vyznačena je těžba rašeliny $v$ katastru obce $v$ těsné blízkosti hranic $v$ císařském otisku stabilního katastru z roku 1843, upraveno podle https://archivnimapy. cuzk.cz.

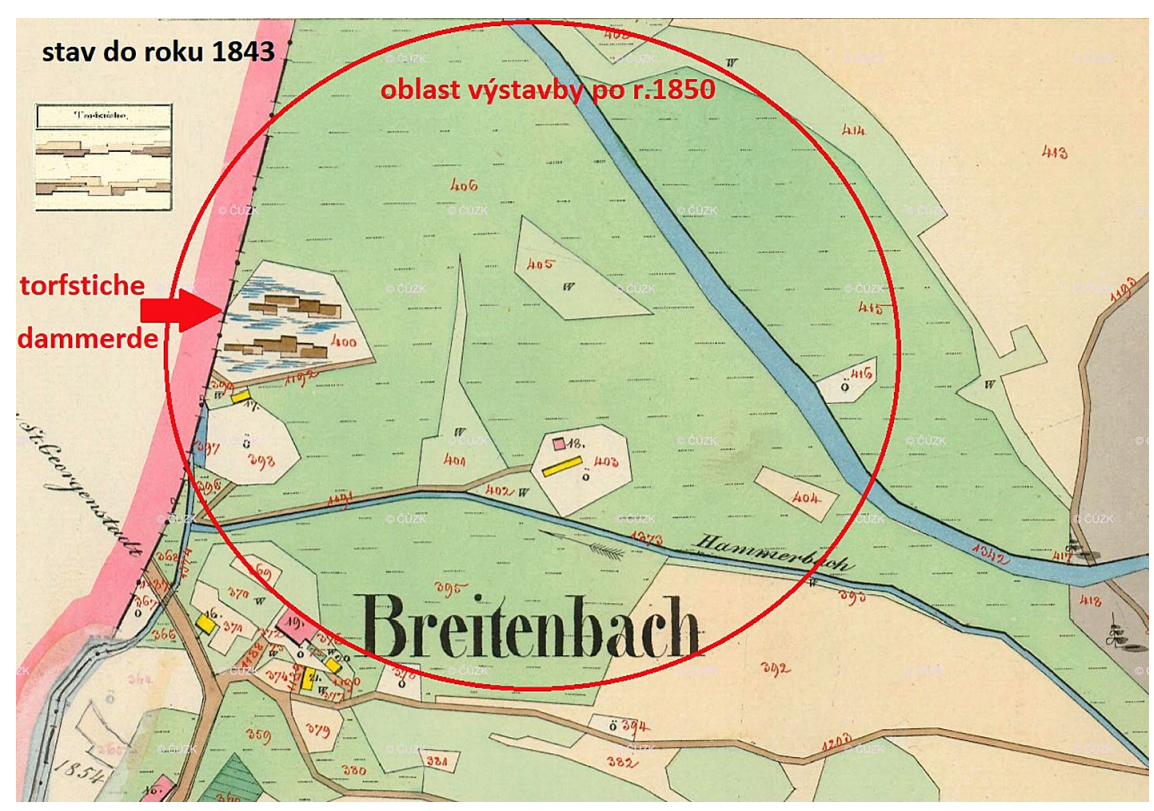

\section{Dopadová plocha meteoritů a výskyt dalších fragmentů meteoritu}

Pro určení předpokládané dopadové plochy byly použity tři známé nálezové body historických pádů meteoritu Steinbach. Body byly odvozeny z dostupných písemných záznamů a jsou pouze pravděpodobným místem jejich dopadu. Na saské straně hranice jde o dopadová místa Steinbach a Rittersgrsrün. Dopadové místo v Rittersgrünu je dnes označeno pamětní tabulí u okraje lesa a leží cca 360 m od státní hranice. Lokalitu Steinbach dnes neIze přesně určit a je pouze orientační. Na českém území jde o historický nález v Potůčkách (Breitenbachu) (obr. 32).

Pro vytipování dalších perspektivních míst, kde by se mohly nacházet další fragmenty meteoritů, bylo využito podkladů z lidarového mapování, které výrazně usnadňuje vyhodnocení ploch zasažených těžbou nerostných surovin. Lidskou činností přeměněná krajina je na lidarovém mapování patrná téměř po celé námi vyznačené dopadové ploše. Digitální model reliéfu nám umožnil vytipovat na vytyčené pádové elipse oblasti s minimálním zásahem do zemského povrchu. Tyto plochy jsme vyhodnotili jako lokality $s$ nejzachovalejším terénem a $s$ nejpravděpodobnější možností učinit nález meteoritu $v$ jeho původní dopadové poloze. Zároveň jsme mohli vyloučit z průzkumu lokality s výrazným recentním poškozením původního terénu. Tímto zpưsobem jsme mohli zmenšit rozsah samotného terénního průzkumu a soustředit se na lokality s největší šancí na nové nálezy. $V$ rámci vytýčené plochy se však již nepodařilo na české straně další oddělky najít, přestože byla oblast podrobena intenzivnímu průzkumu. Díky odlehlosti zalesněných oblastí však nelze nové nálezy meteoritů $v$ budoucnosti vyloučit. Vzhledem k tomu, že jednotlivé kusy byly vystaveny po delší dobu vlivu okolního prostředí, nejsou vzhledově přiliš odlišné od běžných hornin či rudního materiálu vyskytujícího se v okolí. Nález takového kusu ve středověku patrně nevzbudil velkou pozornost a pokud by byl identifikován jako možný zdroj železa, byl by pravděpodobně rozdrcen ve stoupě a překován. To se hypoteticky u části meteoritů mohlo stát. Jejich silikátový podíl, komplikující jejich dalši využití, mohl být důvodem, že se alespoň část dochovala do dneška v původním stavu. Sběr a překovávání starých želez můžeme považovat za běžnou praxi dřivějších kovářských provozů.

Velkou překážkou při průzkumu celkové dopadové plochy je její samotná poloha, která se rozkládá na území dvou států (ČR, SRN) a po celé délce je rozdělená hranicí. Velkým prínosem by byla přihraniční spolupráce a nový terénní průzkum celé plochy předpokládaného dopadu.

Koncentrace čtyř meteoritů na poměrně malé ploše by mohla naznačovat rozpad v prostoru jz. od Johanngeorgenstadtu a postupný dopad dalších kusů v závislosti na hmotnosti jednotlivých oddělků. Pokud budeme předpokládat zákonité uspořádání meteoritů v pádové ploše, mohou nálezy Rittersgrsrün (největší kus o hmotnosti $86.5 \mathrm{~kg}$ ) a Breitenbach (hmotnosti $10.5 \mathrm{~kg}$ ) napomoci rozvrhnout v ose pádu pravděpodobné hmotnosti dalších hypotetických kusů, a to v závislosti na vzdálenosti od obou známých nálezů. $V$ oblasti Rudné by se jejich celková hmotnost mohla odhadem pohybovat okolo 15 - $30 \mathrm{~kg}$. Přesnější stanovení předpokládané hmotnosti meteoritů je metodicky velmi komplikované a mělo by se opírat o řadu dalších informací, které nejsou v prípadě meteoritu Steinbach $\mathrm{k}$ dispozici.

\section{Závěr}

V letech 2017 - 2019 byly při sběru horninových vzorků nedaleko staré hornické lokality Glücksburg u Potůčků nalezeny dvě anomální meteoritická železa s vysokým podílem silikátů o celkové hmotnosti přes $7 \mathrm{~kg}$, klasifikovaná do skupiny IVA-an (železo IVA s anomálními vlastnostmi). Následný výzkum potvrdil jejich shodu s meteority historického nálezu Steinbach. Vzhledem k unikátnímu složení těchto meteoritů a poměrně nejasným okolnostem nálezů jednotlivých historických kusů, učiněných v minulosti na několika místech českého i německého pohraničí, jsme provedli detailní rešerši všech dostupných historických pramenů. Při studiu mineralogického složení obou nově nalezených fragmentů meteoritů jsme potvrdili již dříve známá a publikovaná data, v několika př́ipadech došlo k jejich upřesnění (chromit, schreibersit a niklfosfid); nově byla pro tento typ meteoritu zjištěna prítomnost Fe$\mathrm{Ni}$ sulfidů nestechiometrického složení, odpovídajících většinou Ni-bohatým binárním směsím troilit-godlevskit 
a troilit-heazlewoodit, a $v$ limonitu supergenní fosfát se složením blízkým beraunitu. Na základě koncentrace radionuklidu ${ }^{40} \mathrm{~K} v$ nalezeném meteoritu Ize jeho radiační stárí odhadnout na $70 \pm 30$ miliónů let. Vytýčen byl také hypotetický prostor, ve kterém Ize předpokládat možný výskyt dalších odlomků meteoritu Steinbach.

\section{Poděkování}

Milou povinností autorů je poděkovat recenzentům Milanu Gargulákovi a Romanu Skálovi za řadu podnětů, které umožnily tuto práci publikovat. Za kvalitní fotografie děkujeme též B. Burešovi a D. Velebilovi. Předložená práce vznikla za finanční podpory Ministerstva kultury ČR $\checkmark$ rámci institucionálního financování dlouhodobého koncepčního rozvoje výzkumné organizace Národní muzeum (DKRVO 2019-2023/1.II.b, 00023272).

\section{Literatura}

AlBinus P (1590a) Meißnische Bergk Chronica: Darinnen fürnemlich von den Bergkwercken des Landes zu Meissen gehandelt wirdt /... Geschrieben durch Petrum Albinum... Dreszden M. D. XC, 205 pp. + Register, p. 135

AlBINUs P (1590b) Meißnische Land und Berg-Chronika / In welcher ein vollnstendige description des Landes / so zwischen der Elbe / Sala vnd Südödischen Behmischen gebirgen gelegen / So wol der dormnen begriffenen auch anderer Bergwercken / sampt zugehörigen Metall und Metallarten beschreibungen. ... Gestellet durch Petrum Albinum. Dreszden/ Im 1590. Jar. (449 pp. + Register)

Anonym (1776) Verzeichniß der Foßilien in dem zur allgemeinen Oekonomie gewidmeten Gebäude der kaiserl. königl. theresianischen Akademie. Joseph Kurzböck, Wien, 410 pp. + Register

ANonYm (1866) Festschrift zum hundertjährigen Jubiläum der Königl. Sächs. Bergakademie zu Freiberg am 30. Juli 1866. Dresden (S 287)

Anonym (1873) Journal of Science přináší zprávu o novém nerostu: Asmanit zvaném. Vesmír 1: 16

Anonym (1905) Klement Winkler. Živa 15, 10: 316

ANonym (2009) Im Gothaer Schloss lagert knapp ein Kilo Eisen aus Grimma. Leipziger Volkszeitung vom 18. September 2009

Born I (1772) Index Fossilium quae collegit, et in Classes ac Ordines disposuit Ignatius S. R. I. Eques a Born (Lithophylacium Bornianum), Pragae, Gerle P 125, $157 \mathrm{pp}+$ Index

Breithaupt A (1861) Herr A. Breithaupt an Herrn Beyrich, Freiberg den 17. October 1861. Ztschr Deutsch Geol Gesell 13, 2: 148. Ref. N Jahrb 1862: 490-491

Breithaupt A (1862a) Das Ergebniss der von Herrn Dr. Rube ausgeführten Analyse des Rittersgrüner Meteoreisens. Berg- und huettenmaennische Zeitung (Freiberg, J. G. Engelhardt) 21, 8: 72

BreithAuPt A (1862b) Vorläufige Nachricht über den Eisen-Meteorit von Rittersgrün. Berg- und huettenmaennische Zeitung (Freiberg, J. G. Engelhardt) 21, 37: 321-322

BREZINA A (1895) Die Meteoritensammlung des k. k. naturhistorischen Hofmuseums am 1. Mai 1895. Annalen des k. k. naturhistorischen Hofmuseums (Wien) 10, 3-4: 231-370
Bryson JFJ, Weiss BP, Harrison RJ, Herrero-Albillos J, KronAst F. (2017) Paleomagnetic evidence for dynamo activity driven by inward crystallisation of a metaIlic asteroid. Earth Planet Sci Lett 472: 152-163

BUCHNER O (1863) Die Meteoriten in Sammlungen, ihre Geschichte, mineralogische und chemische Beschaffenheit. Leipzig, 202 pp (124-126)

Burke JG (1986) Cosmic Debris. Meteorites in History. University of Kalifornia Press, $445 \mathrm{pp}$

CLARK WS (1852) On metallic meteorites. MS, Inaugural dissertation on promotion to the rank of Doctor of Philosophy at the Georgia Augusta University by William S. Clark of the United States. Göttingen MDCCCLII (W. F. Kaestner), 79 pp +4 obr. tab. (Meteorit Saxony, p. $20-21+$ Plate II)

COHEN E (1894) Meteoritenkunde. Heft I. Untersuchungsmethoden und Charakteristik der Gemengtheile. Stuttgart, $340 \mathrm{pp}$

Connelly JN, Schiller M, Bizzarro M (2019) Pb isotope evidence for rapid accretion and differentiation of planetary embryos. Earth Planet Sci Lett 525: 1-9

Doelter C (1914) Handbuch der Mineralchemie. Dresden u. Leipzig (Thodor Steinkopff), 2, 1: 190-191, 324-326

DolLASE W A (1967) The crystal structure at $220^{\circ} \mathrm{C}$ of orthorhombic high tridymite from the Steinbach Meteorite. Acta Crystallogr 23: 617-623

Dörfler G, Hecht F, Plockinger E (1965) Elektronenstrahl-Mikroanalyse des Meteoriten von Steinbach. Tscherm Mineral Petrogr Mitt 10: 413-429

EICHLER E, WALtHER H (2007) Sachsen. Alle Städtenamen und deren Geschichte. Faber und Faber Verlag, Leipzig $S 68$

Eugster O, Herzon GF, Marti K, Caffee MW (2006) Irradiation records, cosmic ray exposure agens, and transfer time of meteorites. In: Lauretta D, McSween Hy Jr (eds) Meteorites and early solar system II. University of Arizona Press, Tucson

FABRICIUS G (1565) Georgii Fabricii De metallicis rebvs ac nominibvs observationes variae \& eruditae ex schedis Georgij Fabricij. Tiguri MDLXV, p. 26

FABRICIUS G (1597) Geor. Fabricii chemnicensis Annalivm Vrbis Misnae libri III, 255 pp. + Index, p. 32. In: Georgii Fabricii chemnicensis Rervm Misnicarvm libri VII. lenae MDXCVII. $56 \mathrm{pp}$

FRÖBE W (1994) Herrschaft und Stadt Schwarzenberg bis zum 16. Jahrhundert (1150-1586). Schwarzenberg

Gesner C (1565) De omni rerum fossilium genere, gemmis, lapidibus, metallis et hvivsmodi, libri aliqvot ... Opera Conradi Gesneri: quorum Catalogum sequens folium continet. Tiguri MDLXV

Graham AL, Bevan AWR, Hutchison R (1985) Catalogue of Meteorites. With special reference to those represented in the collection of the British Museum (Natural History). Fourth Edition. University of Arizona Press Tucson, $460 \mathrm{pp}$

HaIDINGeR W (1844) Neuer Fund von Meteoreisen in Ungarn. Wiener Zeitung ze 17. 4. 1844: 843

HAIDINGER W (1845) Handbuch der bestimmenden Mineralogie. Wien (Braumüller), $630 \mathrm{pp}$

HeIDE F (1923) Die Meteorite von Grimma i. S. Central Min: $69-78$

HLAvovÁ J (2016) Správa montánního lesního panství Jáchymov v letech 1546-1873. In: Západočeské archivy Plzeň VII: 27-39 
HowARD E (1802) VII. Experiments and observations on certain stony and metalline substances, which at different times are said to have fallen on the Earth; also on various kinds of native iron. Phil Transact Royal Soc London 92: 168-212

ChARPENTIER JFW (1778) Mineralogische Geographie der Chursächsischen Lande. Leipzig bey S. F. Crucius, $432 \mathrm{pp}, 270-277$

CHLADNI EFF (1808) Beiträge zu den Nachrichten von Meteorsteinen. Annalen der Physik (L. W Gilbert Hsg, Leipzig) 29: 375-383

CHLADNI EFF (1819) Ueber Feuer-Meteore und über mit denselben herabgefallenen Massen. Wien, 434 pp. (Grimma): 92, 212-213; Bornův meteorit Tabor 1753 324; Gotha: 326

Jackson JC, Horton JW, Chou I-M, Belkin H (2011) Monoclinic tridymite in clast-rich impact melt rock from the Chesapeake Bay impact structure. Am Mineral 96: 81-88

JANGL L (1967) Ložiska cínových rud v Krušných horách, 3. část, Vývoj dolování na lokalitě Glücksburg u Podlesí. MS Geofond Praha P019788

JANGL L (1975) Vývoj dolování v blatenském revíru v Krušných horách ve 14 . až 19. století. Studie $z$ dějin hornictví 6: 65-83

Kenngott A (1855) Mineralogische Notizen. 9. Über den Enstatit, eine neue Species in dem Geschlechte der Augit-Spathe. Sitzungsberichte der kaiserlichen Akademie der Wissenschaften (Wien), Mathematisch Naturwissenschaftliche Classe 16: 162-170

KLAPROTH MH (1803) Verhandlungen, die Analyse und den Ursprung meteorischer Stein- und Metallmassen betreffend. $\mathrm{N}$ allgem $\mathrm{J}$ Chem 1, 1: 3-36

LANG V V (1869) Ueber den Enstatit im Meteoreisen von Breitenbach (Mit 1 Tafel). Sitzungsberichte der mathematisch-naturwissenschaftliche Classe der kaiserlichen Akademie der Wissenschaften (Wien) 59, II. Abtheilung: 848-856

LeHMANN JG (1751) Kurtze Einleitung in einige Theile der Bergwercks-Wissenschafen. Berlin, p 79-80

LEYA I, MASARIK J (2009) Cosmogenic nuclides in stony meteorites revisited. Meteorit Planet Sci 44: 10611086

Malina O, SchneiderWinklová P, AugustÝnová M, Černý D (2018) Středověká a novověká kolonizace v západním Krušnohoří. Hornictví jako přičina i následek. In: R Smolnik, N Goryczková (eds.), ArchaeoMontan 2018. Das Erzgebirge im Fokus der Montanarchäologie - Krušné hory v zájmu montánní archeologie. Arbeits- $u$. Forschber sächs Bodendenkmalpfl Beih 32 Dresden - Loket

MASARIK J, REEDY R (1994) Effects of bulk composition on nuclide production processes in meteorites. Geochim Cosmochim Acta 58: 5307-5317

MAson B (1962) Meteorites. John Wiley and Sons, Inc. New York and London

MATZNeR J (1928) První chemické zkoumání povětroňů. Príroda 21: 11

MillaUer M (1825) Přehled potud powědomých Českých powětrných kamenů a kowů (Od Gednatele). Gednánj Společnosti Wlastenského Muzeum w Čechách (W Praze: Schönfeldská impresse), Částka 3: 47-48

Morimoto N, Fabries J, Ferguson AK, Ginzburg IV, Ross M, Seifert FA, Zussman J, Aoki K, Gottardi G (1988) Nomenclature of pyroxenes. Am Mineral 73: 11231133
Nukul A, NakazaWa H, AKaO M (1978) Thermal changes in monoclinic tridymite. Am Mineral 63: 1252-1259

PARTSCH P (1843) Die Meteoriten oder vom Himmel gefallenen Steine und Eisenmassen im k. k. Hof-Mineralien-Kabinette zu Wien, 162 pp (91-95 Sachsen; 95-97 Bitburg)

Рӧтzsch ChG (1804) Kurze Darstellung der Geschichte über das Vorkommen des gediegenen Eisens, sowohl des mineralischen als auch des problematisch-meteorischen, und anderer darauf Bezug habenden Aerolithen, mit eigenen Wahrnehmungen die auch das Daseyn des erstern in dem Innern unsers Erdkörpers auf Lagern oder Gängen zu bestätigen scheinen. Dresden (Walther), 120 pp (p. 4-17)

Pouchou JL, PICHOIR F (1985) "PAP" ( $\varphi \rho Z)$ procedure for improved quantitative microanalysis. In: Microbeam Analysis (J. T. Armstrong, ed.). San Francisco Press, San Francisco: 104-106

Povinec PP, Masarik J, Sýkora I, Kováčik A, Beño J, LauBENSTEIN M, PORUBČAn V (2015) Cosmogenic radionuclides in the Košice meteorite: Experimental investigations and Monte Carlo simulations. Meteorit Planet Sci 50: 880-892

Povinec PP, Sýkora I, Ferriere L, Koeberl C (2020) Analyses of radionuclides in the Oued Awlitis 001 and Galb Inal lunar meteorites by HPGe gamma-ray spectrometry. J Radioanal Nucl Chem 324: 349-357

PRESL JS (1833) O powětronjch. Časopis Českého museum (Praha) 7, 2: 206-227; 3: 299-315; 2: 206-227

QUENSTEDT FA (1872) Meteorsteine. In: Klar und Wahr. Neue Reihe populärer Vorträge über Geologie. Tübingen (Laupp), VIII + 322 pp., 1 lithogr. Taf. u. zahlr. Holzschn. (280-322 Meteorsteine; 284 Bitburg; 291-292 Steinbacher Seifengebirge; 292 - obrázek destičky Breitenbach)

RATH G (1873) Mineralogische Mittheilungen. Annalen der Physik und Chemie Ergänzungs-Band 6, Stück 3: 382-384

Ried Am, Williams RJ, Takeda H. (1974) Coexisting bronzite and clinobronzite and the thermal evolution of the Steinbach meteorite. Earth Planet Sci Lett 22: 67-74

Rose G (1864) Protokoll der Mai-Sitzung. Ztschr Deutsch geol Gesell (Berlin), 16, 3: 355-356

RUZICKA A (2014) Silicate-bearing iron meteorites and their implications for the origin of asteroidal parent bodies. Chem Erde 74: 3-48

RuZicka A, Hutson M (2006) Differentiation and evolution of the IVA meteorite parent body: Clues from pyroxene geochemistry in the Steinbach stony-iron meteorite. Meteorit Planet Sci 41: 1959-1987

ScOTT ERD, HAACK H, McCoY TJ (1996) Core crystallization and silicate-metal mixing in the parent body of the IVA iron and stony-iron meteorites. Geochim Cosmochim Acta 60: 1615-1631

Schalch F, GÄBERT C (1900) Geologische Specialkarte des Königreichs Sachsen. Section Johanngeorgenstadt (No. 146). Geolog. Aufnahme von F. Schalch abgeschlossen i. J. 1884. Geologische Revision zur 2. Auflage ausgeführt von C. Gäbert i. J. 1899 u. 1900. Giesecke \& Devrient Leipzig

SCHALCH F, GÄBERT C (1901) Erläuterungen zur geologischen Specialkarte des Königreichs Sachsen. Bearbeitet unter der Leitung von Hermann Credner. Section Johanngeorgenstadt: Blatt 146 von F. Schalch. Zweite Auflage. Revidiert von C. Gäbert i. J. 1899 und 1900. Engelmann, Leipzig, 86 pp. (Eisenmeteorit von Rittersgrün p. 85-86) 
Schneiderwinklová P, Augustýnová M, Malina O, Černý D, (2018) Úprava a zpracování cínových rud v povodí Černé a Bystřice. In: Smolnik R, Goryczková N, eds ArchaeoMontan 2018. Das Erzgebirge im Fokus der Montanarchäologie - Krušné hory v zájmu montánní archeologie. Arbeits- und Forschberichte der sächsischen Bodendenkmalpflege. Beih 32 Dresden - Loket

Stieglitz ChL (1769) Spicilegium quarundam rerum naturalium subterranearum Lipsiae collectarum. Editum Anno MDCCLXIX. Leipzig. Taf. II

Story-MAskelyne N (1869) Preliminary notice on the mineral constituents of the Breitenbach meteorite. Proc Royal Soc London 17, 111: 370-372. Ref. Ztschr Kristallogr (Leipzig), 2 (1878): 273-274

StORY-MASKELYNE N (1870) On the mineral constituents of meteorites. Phil Transact Royal Soc London 160: 189-214

StORY-MASkELYNE N (1871) On the mineral constituents of meteorites. Phil Transact Royal Soc London 161: 359-365

Sтоу JF (1751) Nachricht von gediegenem Eisen. Hamburgisches Magazin, oder gesammlete Schriften, zum Unterricht und Vergnügen, aus der Naturforschung und den angenehmen Wissenschaften überhaupt (Hamburg, bei G. Ch. Grund u. Leipzig bei A. H. HoIle), 7, 4: 441-445

STROMEYER F (1824) Göttingen. Göttingische gelehrte Anzeigen. Unter der Aufsicht der königl. Akademie der Wissenschaften. Der dritte Band auf das Jahr 1824 (Göttingen): 2073 -2083 (referát o jeho přednášce „De Olivini, Chrysolithi et fossilis, quod cellulas et cavernulas ferri meteorici Pallasii explet, analysi chemica“)

Tschermak G (1883) Beitrag zur Classification der Meteoriten. Sitz.-Ber. K. Akad. Wiss., math.-naturwiss. KI. (Wien) 88, $2:$ 347-371

TUČEK K (1968) Catalogue of the Collection of Meteorites of the National Museum in Prague. Národní muzeum Praha, $101 \mathrm{pp}$ (69-70)

TUČEK K (1981): Meteority a jejich výskyty v Československu. Academia, Praha $270 \mathrm{~s}$

Ulff-Møller F, Rasmussen KL, Kallemeyn GW, Prinz M, Palme EH, Spettel B (1995) Differentiation of the IVA parent body: Evidence from silicate-bearing iron meteorites. Geochim Cosmochim Acta 59: 4713-4728

VRBA K (1896) O meteoritech. Živa 6, 1: 1-6

Wasson JT, Matsunami Y, Rubin AE (2006) Silica and pyroxene in IVA irons; possible formation of the IVA magma by impact melting and reduction of L-LL-chondrite materials followed by crystallization and cooling. Geochim Cosmochim Acta 70: 3149-3172

WEISBACH A (1876) Der Eisenmeteorit von Rittersgrün im sächsischen Erzgebirge. Verlag d k Bergakademie Freiberg, 3 Seiten
WeIsS J (1845) Veranlassung zum Funde der Meteor-Eisenmassen bey Szlanicza im Arvaer Comitat und Beschreibung des Fundortes. Wiener Zeitung z 30. 3. 1845: 678

WINKLER C (1878) Untersuchung des Eisenmeteorits von Rittersgrün. Nova Acta der Ksl. Leop.-Carol.-Deutschen Acad der Naturforscher (Halle) 11, 8: 331-382

WüLfING EA (1897) Die Meteoriten in Sammlungen und ihre Literatur. Tübingen (H. Laupp), 460 pp

YANG J, Goldstein JI, Scott ERD (2008) Metallographic cooling rates and origin of IVA iron meteorites. Geochim Cosmochim Acta 72(12): 3043-3061

Poznámka: téměř všechny publikace a články v starých periodicích, citované v této práci a které již nepodléhají copyrightu, tedy až do počátku 20. století, jsou digitalizované na webu, např. Google Books https://books.google. com/, Biodiversity Heritage Library https://www.biodiversitylibrary.org/, https://www.zobodat.at/ a jinde. Dále byly využity následující internetové odkazy:

Meteoritical Bulletin Database (Steinbach): https://www. Ipi.usra.edu/meteor/metbull.php?code $=23722$

http://wiki.meteoritica.pl/index.php5/Steinbach (Meteoriti$\mathrm{ca} /$ Steinbach. Unless otherwise stated, the copyright of the materials included belong to Jan Woreczko \& Wadi.)

https://www.mindat.org/loc-67523.html

Meteorit Rittersgrün vyobrazení 1878: https://digital.slub -dresden.de/en/workview/dlf/180394/11/

Permalink page: https://sachsen.digital/werkansicht/ dlf/180394/1/

Steinbach meteorite (Potůčky; Breitenbach; Eibenstock; Gotha; Grimma; Johanngeorgenstadt; Rittersgrün):

Charpentier 1778 - mapa: (http://www.deutschefotothek. de/documents/obj/70402801/df_dk_0006113)

https://cs.wikipedia.org/wiki/Vad\%C5\%BEra\#/media/ Soubor:Vajra.jpg (Vadžra, a'sman?)

Geologická mapa Království saského a Vysvětlivky (1900 a 1901):

http://wiki.meteoritica.pl/images/2/25/Steinbach_\%28 Credner_map_sektion-146\%29.jpg

https://digital.slub-dresden.de/werkansicht/dlf/24489/1/

https://royalsocietypublishing.org/

Ramanovo spektrum monoklinického tridymitu: http:// www.ens-lyon.fr/LST/Raman/spectrum.php?nom=tridymite 